PIOTR CABAN

KAZIMIERZ STOIŃSKI

MAREK ROTKEGEL

SYLWESTER RAJWA

ADAM GNATOWSKI

KRZYSZTOF PACZEŚNIOWSKI

\title{
The evolution of steel frame sets for longwall development drifts
}

\begin{abstract}
The article presents the development of steel frame sets produced for mining purposes by Huta Łabędy S.A., intended for securing gallery workings, and longwall development drifts in particular. In recent decades, longwall development drift support has evolved in terms of characteristics such as its shape. The initially utilised rectangular frames and typical widened $Ł P$ frames were replaced with flat frames based on $Ł P$ arches ( $Ł P K O)$, and subsequently with special frame sets adapted to the shape of powered support units. The intermediate frame shape obtained in this way was a compromise between the rectangular (beneficial from the perspective of longwall equipment and development) and the arching design (beneficial due to the high load-bearing parameters).
\end{abstract}

Key words: frame set, road support, longwall development drift

\section{INTRODUCTION}

In the beginning of underground coal mining plant operations, the technology employed was only mechanised to a very minor degree. The deposits were extracted at shallow depths of $200 \mathrm{~m}$ to $350 \mathrm{~m}$. As technology progressed, increasingly deeper deposits were mined, and their effective extraction required the application of advanced methods and technologies, such as the use of longwall shearers. Mining by means of the longwall method requires the excavation of a specific system of preparatory gates, such as longwall development drifts. It is a particular group of large and short-lived gallery workings, characterised by a significant height and width adapted to the deposit awaiting extraction. Longwall development drifts are driven in order to install the powered longwall support and the necessary auxiliary equipment enabling the development of the longwall and the ex- traction of the coal deposit. Today, there are about 60-70 longwall development drifts driven yearly in Polish hard coal mines. Considering the average longwall length, this corresponds to about $13 \mathrm{~km}$ of workings, which, assuming a spacing of $0.75 \mathrm{~m}$, requires the application of frame sets with a total weight of nearly 8 thousand tonnes. In a global scale, this therefore constitutes a significant number of support elements.

The purpose of the article is to present the full spectrum of frame sets produced at Huta Labędy over the last 30 years, intended for securing longwall development drifts. The presented frame set structural solutions make it possible to secure longwall development drifts while factoring in the dimensions of all the powered support systems utilised in hard coal mines. The presented constructions were designed at the Central Mining Institute in cooperation with Huta Łabędy and various hard coal mining plants, 
such as KWK Ziemowit, KWK Wesoła, LW Bogdanka, KWK Bobrek, KWK Wujek, KWK Pniówek, KWK Zofiówka and the already decommissioned Katowice and Kleofas mines. The mines made a significant contribution in terms of the verification of the support frames and their operational qualities, which served as the basis for certain corrections and structural detail enhancements introduced at the Central Mining Institute. Such a cooperation of these three entities in terms of the new frame set solution implementation makes it possible to combine GIG's design and testing experience with the robust manufacturing capabilities of Huta Łabędy, while including the needs and observations of the users, i.e. the mines. Huta Łabędy manufactures the presented frame sets using modern steel such as $25 \mathrm{G} 2 \mathrm{Ti}$, S480W [1] and S550W [2], which guarantees their high mechanical strength parameters and increased resistance to corrosion.

\section{ORIGINS OF LONGWALL DEVELOPMENT DRIFT SUPPORT FRAMES}

In the beginning of hard coal extraction via longwall mining with the use of longwall shearers, longwall development drift support was constructed by means of $Ł P$-type yielding arch frames [3-5].

A drawback of this solution was the necessity to fill a significant space in the roof between the powered support canopy and the top section of the arch support with timber to ensure the appropriate spragging of the powered support at the stage of longwall equipment and mining commencement. Eventually, ŁP frames with shortened side sections were applied in order to reduce the roof lining space, which decreased the amount of timber used for cribbing, thereby also reducing the time and costs required for equipping the longwall.

Rectangular frames were used as an alternative solution, where the straight top section made it easier to sprag the powered support units. However, the low load capacity of such a support limited the scope of its application [6, 7]. It was necessary to reinforce the straight top section. One such solution was the trapezoid support, designated with the letters OPP, whose structural variants are presented in Figures 1 to 3 [8]. Depending on the roof conditions, the top section is either to be supported by a catch prop or bolted.

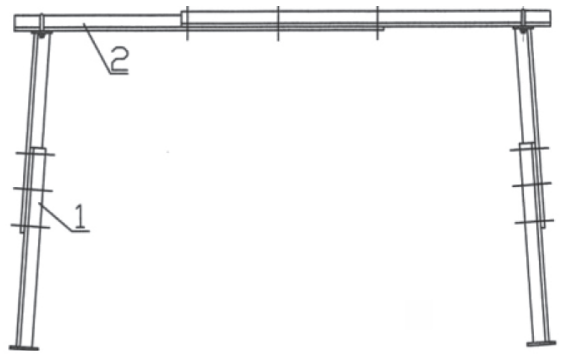

Fig. 1. OPP frame, variant 1:

1 - prop (supporting element), 2 - straight top section

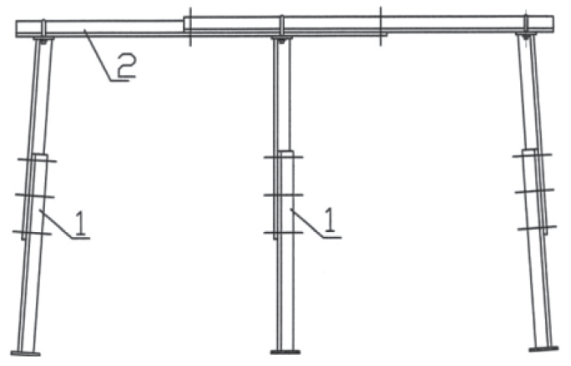

Fig. 2. OPP frame, variant 2:

1 - prop (supporting element), 2 - straight top section

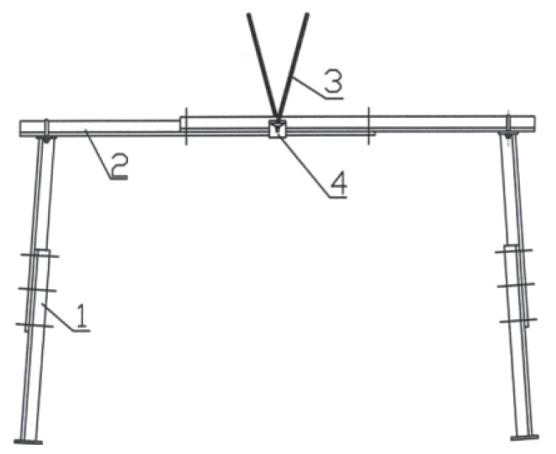

Fig. 3. OPP frame, variant 3:

1 - prop (supporting element), 2 - straight top section,

$$
\text { 3-bolt, 4-washer }
$$

Progress towards the geometric optimisation of frames intended for securing longwall development drifts led to the drafting of a support catalogue [9] containing proposed series of frame set types designed for securing longwall development drifts. The series of frame sets included in the catalogue factored in the parameters of the powered support units commonly employed at the time. It was adopted as a principle that the unit transport length (diameter of a unit in transport position increased by 5\%) would constitute the basic criterion determining the possibility of introducing a given type of powered support into a specific longwall development drift support. Adopting this principle in longwall development drift support frame selection ensured the possibility of manoeuvring with an introduced powered support unit in transport position. The main designs in the aforementioned catalogue that gained the approval of mining plants and 
saw common application in practice included the series of three-element (coupled) ŁPK frames presented in Figures 4 and 5 [9] and four-element (combined) $Ł P K O$ frames. The $Ł P K$ frames were configured using the top and side sections of various sizes adapted from three-element $P$ frames sized 5 to 10 [9]. Figures 6 and 7 [10] present a development drift support secured with an $\mathrm{EPK}$ support, and the longwall equipment. On the other hand, the $Ł P K O$ series was configured using two pairs of side sections of various sizes, adapted from three-element $\iota P$ frames sized 4 to 8 .

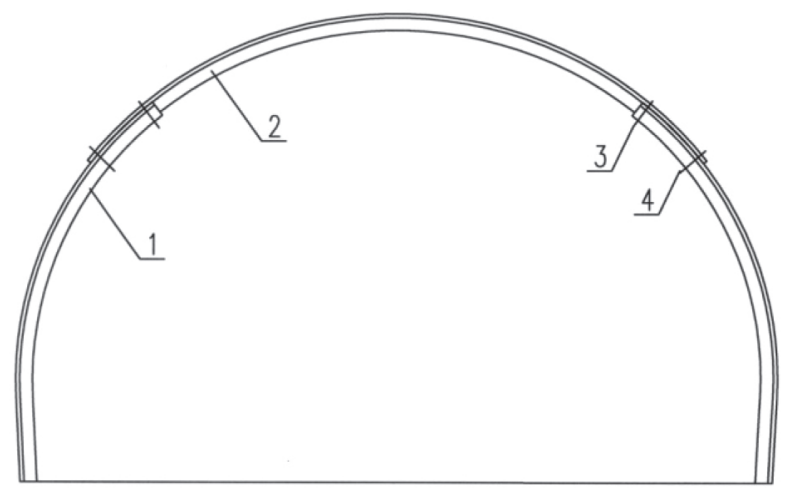

Fig. 4. ŁPK frame (coupled):

1 - side section, 2 - top section, 3, 4- shackles

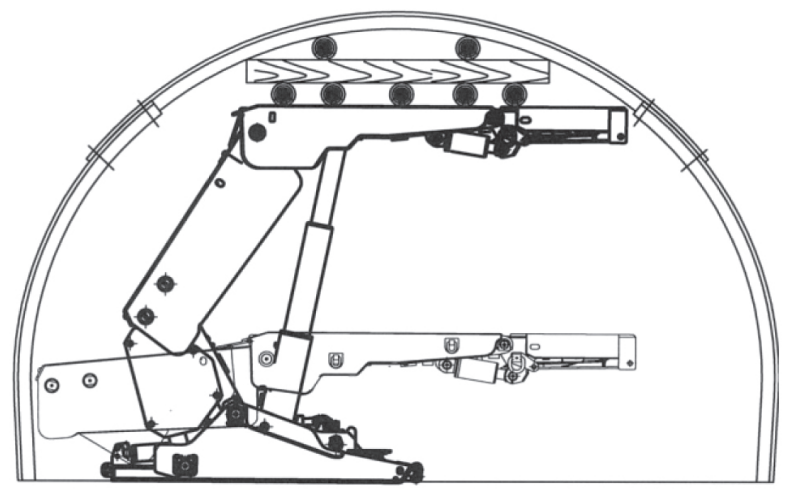

Fig. 5. Coupled $Ł P K$ frame with an installed powered support unit (unit before and after spragging)

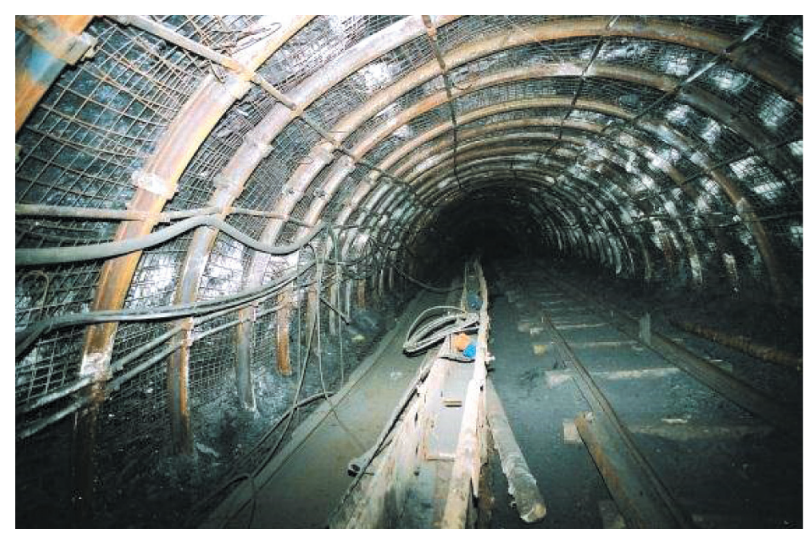

Fig. 6. Development drift driven in coupled $Ł P K$ frames with shortened side sections

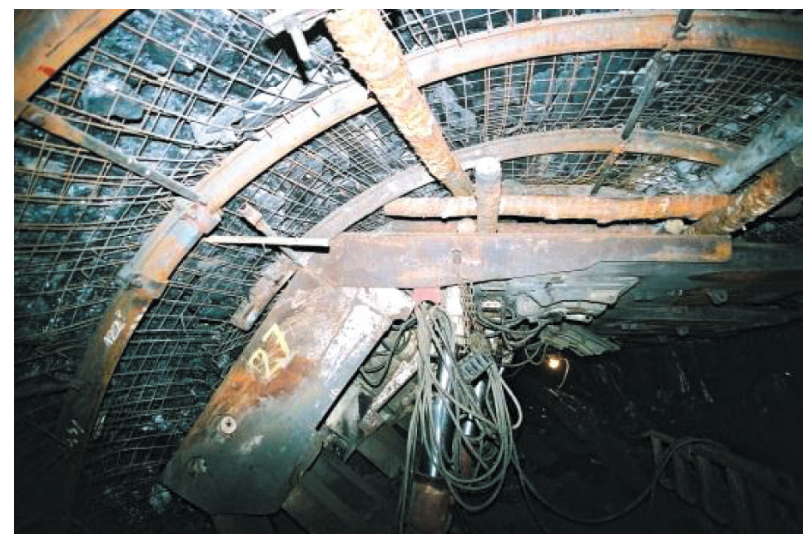

Fig. 7. Longwall equipment, development drift driven in coupled $€ P K$ frames

The experience gained during the longwall development drift performance, and the subsequent equipping and development commencement of the longwall, resulted in a rapid evolution of the designs towards specialised frame sets intended primarily for securing such workings.

\section{WORK AND RESEARCH ON FRAME SET DESIGN DEVELOPMENT}

Work on new structural solutions for frame sets intended for securing longwall development drifts was based primarily on the observations of the operation and functionality of already installed frames. These observations encompassed the entire working life cycle - from the driving, through the equipping to the development of the longwall. The numerous discovered deficiencies of the standard $\mathrm{LP}$ supports, the coupled $\mathrm{LPK}$ frames and the rectangular frames motivated the mining plants as well as the support designers and manufacturers to seek solutions that would improve the support functionality. As a result of these efforts, numerous frame set solutions were designed, which constituted a compromise between the arching $\mathrm{P}$ support (with high load-bearing parameters but unfavourable shape for the powered support unit spragging and longwall mining commencement) and the rectangular support (with low load-bearing parameters but better functionality from the perspective of longwall equipment and mining commencement). The research and development work was conducted at the Department of Extraction Technologies, Rockburst and Mining Support and the Department of Mechanical Devices Testing and Rocks of the Central Mining Institute in Katowice. 
The work encompassed frame set design based on the end-user requirements as well as laboratory and model testing, and appropriate certification.

Model testing is the key stage of design work. Combined with bench testing and its results, it enables the calibration of numerical models to determine the load-bearing parameters of an entire series of frames [11, 12]. The numerical analysis results are particularly important in the design and optimisation of frames with geometries diverging from typical $P$ frames, as is the case with flat frames of archingstraight shapes. These analyses are performed using the finite element method [13, 14], e.g. by means of the COSMOS/M software $[15,16]$. A geometric model of the frame is constructed during the first stage, factoring in its dimensions and cross-sectional parameters. The appropriate material parameters are defined in the next steps. The key issue, particularly when modelling arching-straight frames, is to define the frame bearing and load case. The great significance of these factors can be observed by analysing the results of the simulated operation of an arching-straight $Ł P r P$ frame. To demonstrate this issue, a strength analysis was performed for a size 28 six-element $\measuredangle P r P$ frame with a nominal width of $6200 \mathrm{~mm}$ and height of $2600 \mathrm{~mm}$, constructed from V29 sections [17] rolled using $25 \mathrm{G} 2$ or $34 \mathrm{GJ}$ steel (per standard PN-H-93441-1 [18]). In order to carry out these analyses, a model of the frame was constructed using 126 beam elements corresponding to the arching sections, 10 beam elements corresponding to the shackles and 6 spring elements corresponding to the pressure exerted by ribs with a given stiffness. The full model is presented in Figure 8. Deformed frame shapes, bearing reaction values, internal force distributions and coloured reduced stress maps were obtained as a result of the performed simulations. An example of reduced stress distribution is presented in Figure 9.

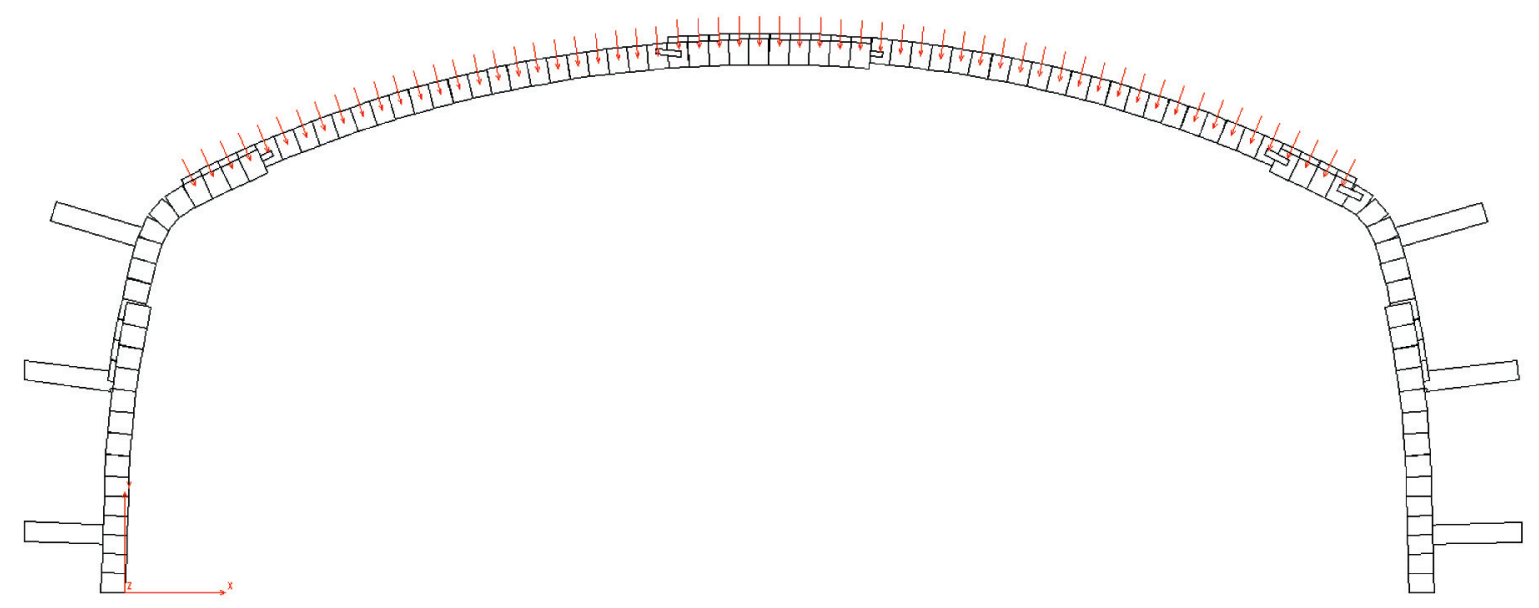

Fig. 8. $\mathrm{APrP} / 6 / \mathrm{B} / 28$ frame model $(6200 \mathrm{~mm} \times 2600 \mathrm{~mm})$

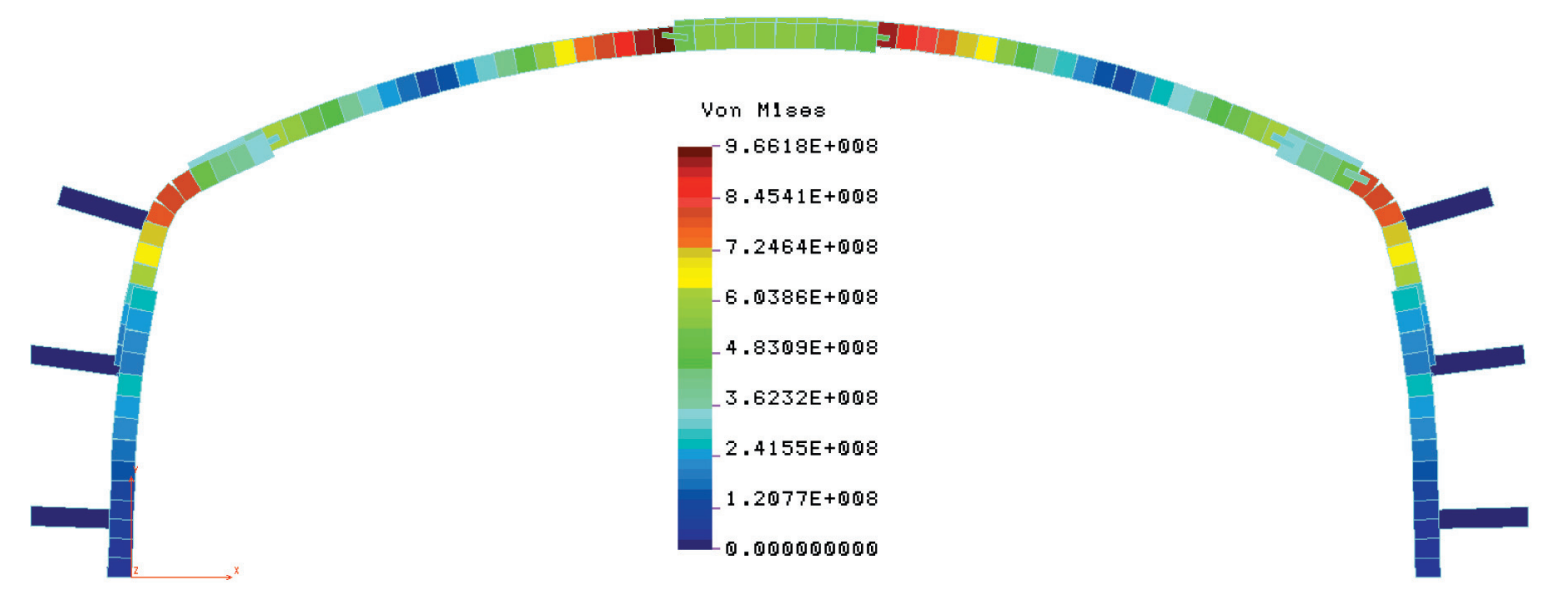

Fig. 9. Reduced stress distribution in the $Ł P r P$ frame

(stress in Pa, scale of deformation 1x, rib pressure element stiffness $k=1 \mathrm{MN} / \mathrm{m}$, loaded

top section length $2.18 \mathrm{~m}$ ) 
The influence of the frame loading method (loaded top section length) and of the rib pressure element stiffness on the frame load capacity was analysed during the tests. This factored in the strength of the V29 section formed from steel according to standard PN-H-93441-1 [18]. The analyses demonstrate that the frame load capacity increases significantly together with the increase in the loaded top section length. This can be clearly observed in the chart depicted in Figure 10. In the case of the analysed model and the stiffness of each of the elements modelling the rib pressure (the springs) at a level of $k=15 \mathrm{MN} / \mathrm{m}$, a frame subjected to an almost single-point load (loaded top section length $L=200 \mathrm{~mm}$ ) exhibits a load capacity of $N=183 \mathrm{kN}$, whereas when the load is applied over a length of $5.94 \mathrm{~m}$, the load capacity achieves the value of $N=417 \mathrm{kN}$.

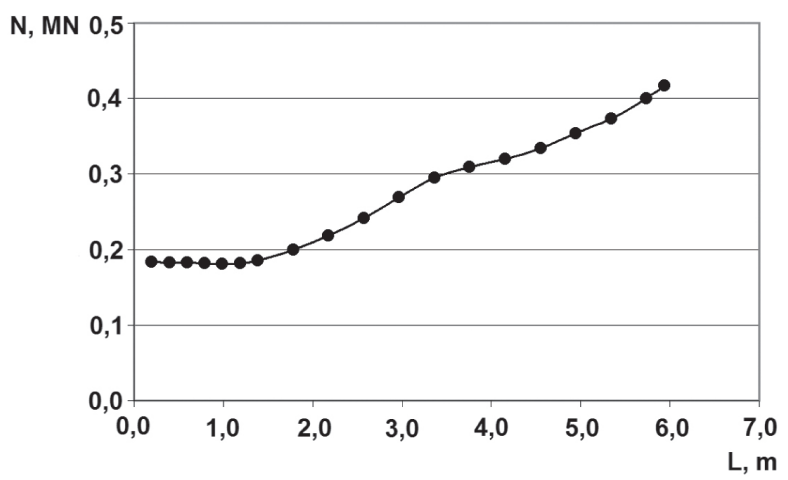

Fig. 10. Frame load capacity $N$ depending on the loaded top section length $L$ for a stiffness $k=15 \mathrm{MN} / \mathrm{m}$ of the elements modelling the rib pressure
Very interesting conclusions can also be drawn by analysing the influence of the rib pressure element stiffness on the frame load capacity. Assuming that the load is applied over the entire length of the top section, depending on the rib pressure element stiffness the frame load capacity can vary from $72 \mathrm{kN}$ at no rib pressure to $417 \mathrm{kN}$ at a tight, stiff encasement. These variations are presented as a chart in Figure 11. This indicates the need to ensure a tight pressure exerted by the ribs, particularly at the points where the roof borders the ribs.

Additional attention was dedicated to the internal forces and reduced stresses in the arching sections, generated by the maximum load applied to the frame. Table 1 presents the values of these parameters in key locations.

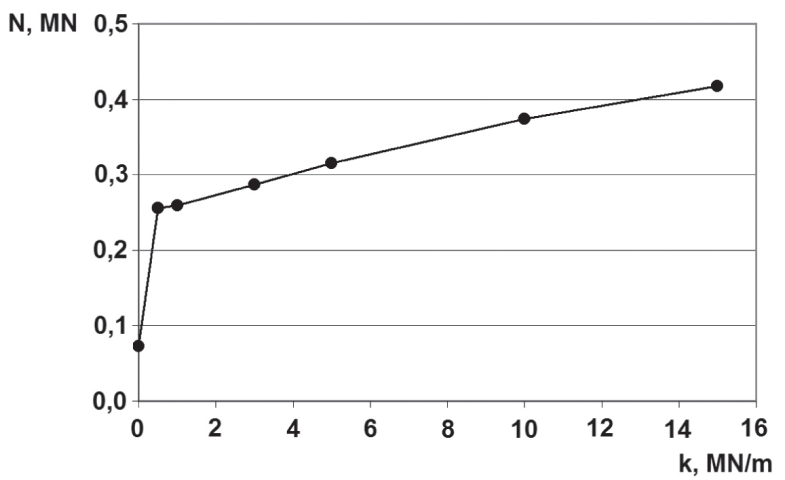

Fig. 11. Frame load capacity $N$ depending on the stiffness $k$ of the elements modelling the rib pressure at a load applied over the entire length of the top section

Table 1

Internal forces and reduced stresses in key frame locations once the load capacity is achieved for a load case applied over the entire length of the top section and for selected rib pressure element stiffnesses (locations with loss of V29 section load capacity in bold)

\begin{tabular}{|c|c|c|c|c|c|c|}
\hline \multirow[t]{2}{*}{ Place of measurement } & $\begin{array}{l}\text { Stiffness of } \\
\text { elements } \\
\text { modelling the } \\
\text { rib pressure }\end{array}$ & \multirow[t]{2}{*}{ Location } & $\begin{array}{l}\text { Axial } \\
\text { force }\end{array}$ & $\begin{array}{l}\text { Shearing } \\
\text { force }\end{array}$ & $\begin{array}{l}\text { Bending } \\
\text { moment }\end{array}$ & $\begin{array}{l}\text { Reduced } \\
\text { stress }\end{array}$ \\
\hline & $k[\mathrm{MN} / \mathrm{m}]$ & & $N[\mathrm{kN}]$ & $T[\mathrm{kN}]$ & $M g[\mathrm{kNm}]$ & $\sigma_{\text {red }}[\mathrm{MPa}]$ \\
\hline \multirow{6}{*}{$A$} & \multirow{2}{*}{0} & A & 19.3 & 29.2 & 10.0 & 143.8 \\
\hline & & B & 8.8 & 6.5 & 57.7 & 625.0 \\
\hline & \multirow{2}{*}{0.5} & A & 139.7 & 56.1 & 50.9 & 581.7 \\
\hline & & B & 115.9 & 15.9 & 54.3 & 625.0 \\
\hline & \multirow{2}{*}{15.0} & $\mathbf{A}$ & 331.9 & 23.9 & 47.6 & 625.0 \\
\hline & & $\mathrm{B}$ & 312.9 & 16.3 & 31.4 & 434.6 \\
\hline
\end{tabular}


As can be seen in the presented compilation, in the event of no rib pressure, the top section experiences failure close to the sliding joint (location B). Great bending moments are generated in this location, whereas the frame operates as if rigid, since there can be no yielding in the overlaps at minor axial force values [19-21]. This situation occurs already at very low loads. On the other hand, at high rib pressure the loss of frame load capacity occurs due to the exceeded strength of the corner element at the location characterised by great curvature. At the same time, the stresses in the top section exhibit significantly lower values, whereas the great axial forces and the low bending moment at the sliding joint enable a yield in the overlaps and the yielding operation of the frame. Additionally, the presented analysis reveals the significance of the corner element in relation to the load capacity of the entire frame. This element must be constructed with precision and using the appropriate materials, particularly given that the bend- ing of a V section at such a small radius entails a number of requirements concerning the material parameters.

Full scale frame prototypes are tested at the test facility of the Department of Mechanical Devices Testing and Rocks of the Central Mining Institute, depicted in Figure 12. During testing, frames in both rigid and yielding states are subjected to static loads. The purpose of the tests is to determine the actual load-bearing and deformational parameters of a new frame set and to confirm its correct operation. The frame tests were carried out according to standard PN-G-15000-05 [22] in the past, whereas today they are conducted per standard PN-G-15022 [23]. These standards define the applied bearing and loading methods as well as the remaining parameters of the tests. Figure 13 presents a load case for a frame tested at the test facility. Apart from the full frame sets, tests are also conducted for sliding joints, which are responsible for the correct operation of the frames [19-21].

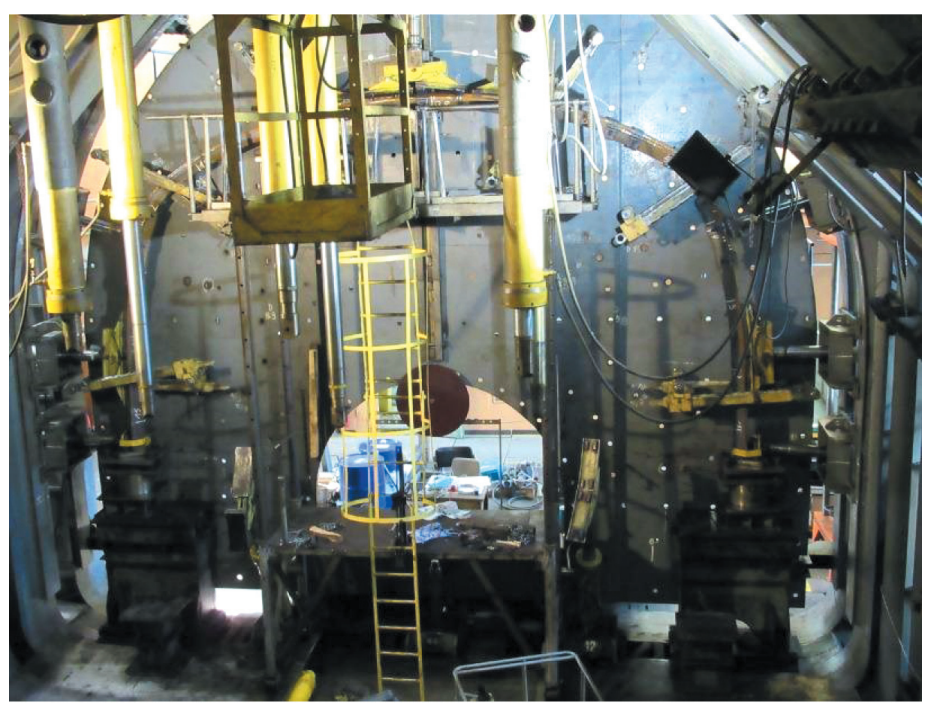

Fig. 12. Test facility with an installed frame during testing

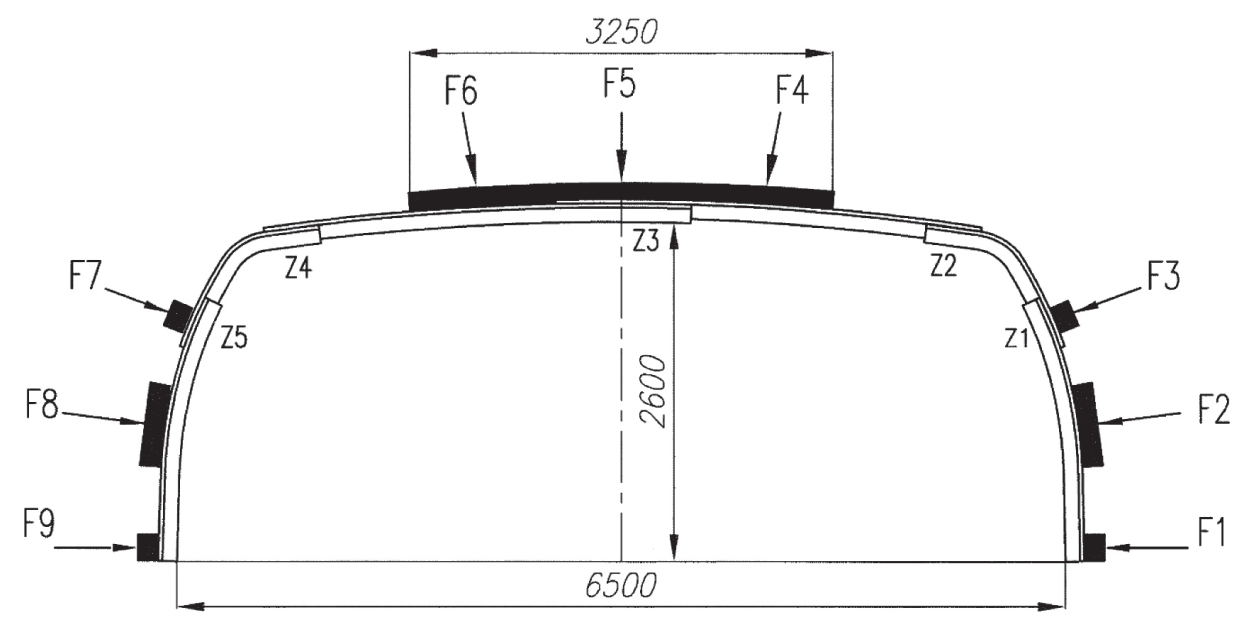

Fig. 13. Load case for an arching-straight frame tested at the test facility $F_{4}, F_{5}, F_{6}$-active forces, $F_{1}, F_{2}, F_{3}, F_{7}, F_{8}, F_{9}$ - passive forces 
The results obtained from the frame set bench tests enable comparisons with the results of numerical calculations, and the results of tests involving different constructions intended for development drifts as well as standard $Ł P$ support frames. The result analysis also makes it possible to improve the digital frame models (model calibration) and serves as the basis for introducing potential changes in the frame structures. A report from the frame bench tests as well as the operation and maintenance documentation are the basis to grant a manufacturer a certificate for marking the frames with the safety symbol "B" (B).

\section{FRAMES FOR LONGWALL DEVELOPMENT DRIFTS PRODUCED BY HUTA ŁABĘDY}

One of the first structural solutions dedicated to securing longwall development drifts was the ŁPKO frame series. It was designed based on suggestions included in the 1995 draft catalogue [9] and the mining experience gained during the performance of prepa- ratory work. The series was systematised and expanded with new variants constructed from all the V-type sections that are commonly employed in mines. The $Ł P K O$ and $Ł P K O w$ support frames are primarily intended for securing the longwall development drifts prepared for the installation of powered support units. The ŁPKO frame design utilises the standard and mass-produced side sections of the three-element $\mathrm{LP}$ and $Ł P P$ frames (sized 7-10). To ensure a precise fit of the frame geometry to the planned working, it is permitted to modify the frame by shortening the side section from the direction of the straight part and by changing the size of the overlaps. In recent times, the ŁPKO frame series was expanded with the $\mathrm{LPKOw}$ variant based on the side sections of the three-element $Ł P w$ and $Ł P P w$ frames, which are characterised by a single bend radius of the side and top sections [24-27]. The expanded series encompasses frames with widths of $5400-8485 \mathrm{~mm}$ and heights of $3145-5320 \mathrm{~mm}$. Figures 14 and 15 present the $Ł P K O w$ and $Ł P K O$ frame structures, whereas Figure 16 [28] depicts a development drift secured by means of the ŁPKO support.

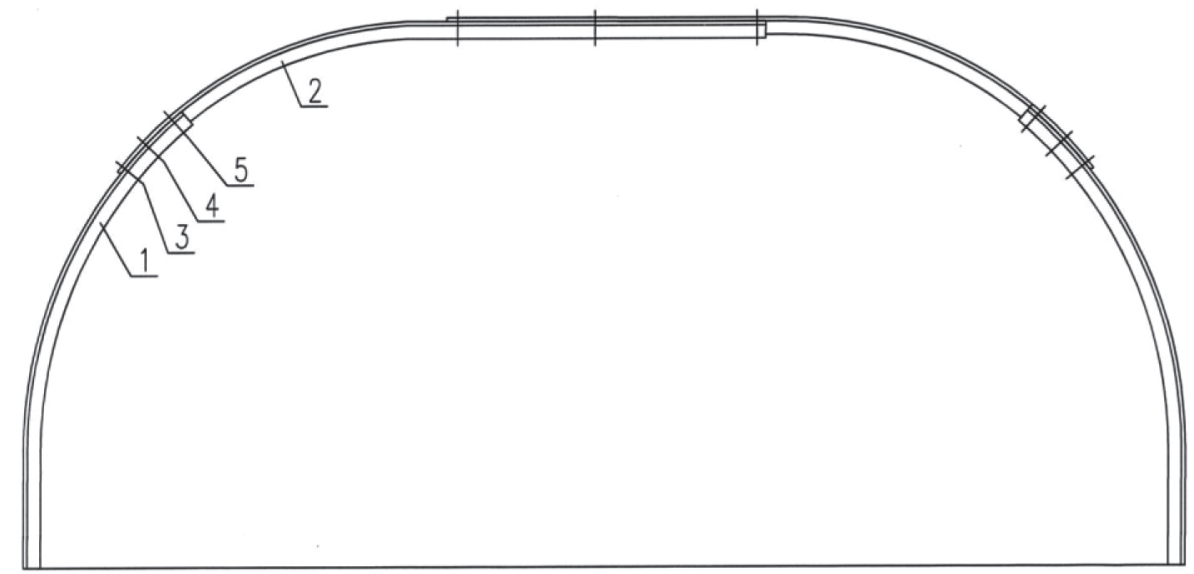

Fig. 14. ŁPKOw frame: 1 - ŁP frame side section, 2 - ŁPP frame side section installed as the top section, 3-5-shackles

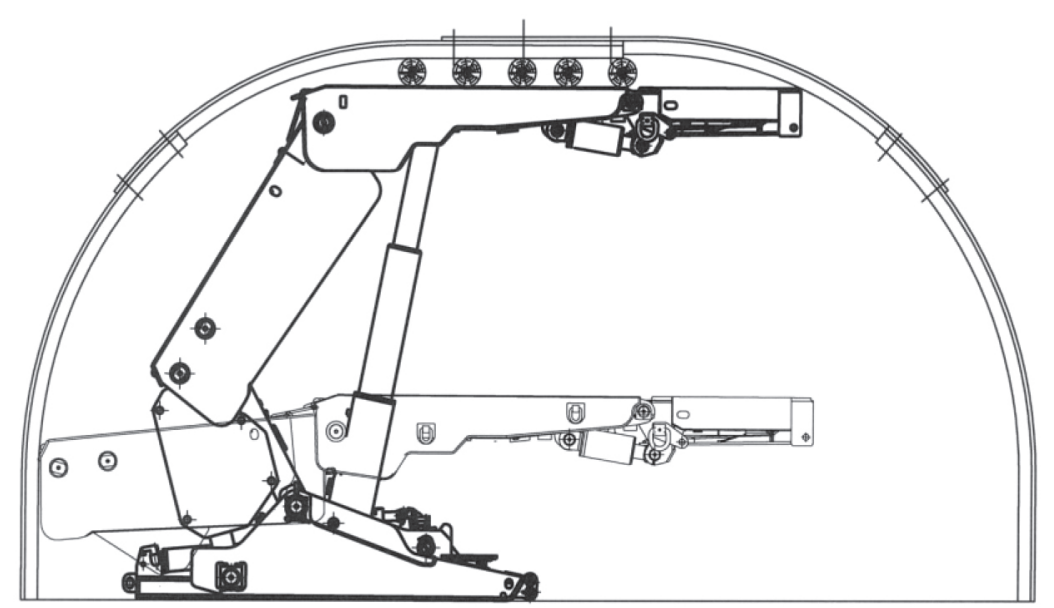

Fig. 15. ŁPKO frame with an installed powered support unit (unit before and after spragging) 


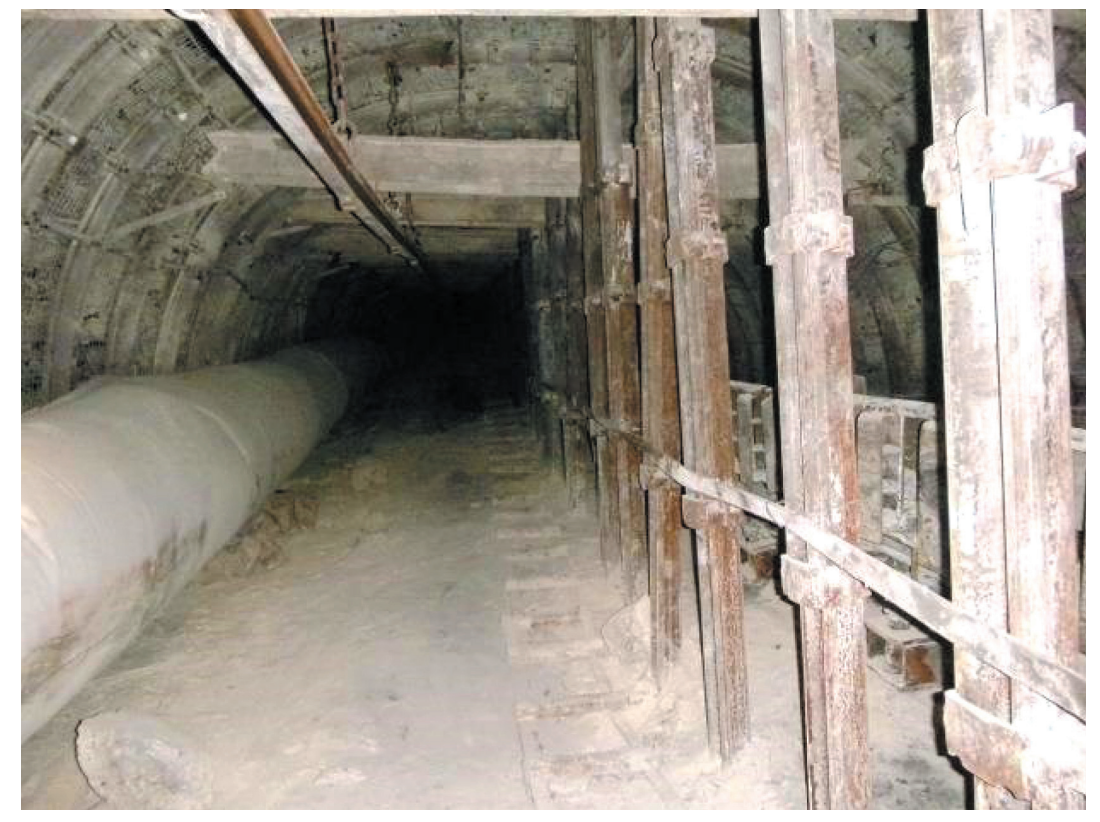

Fig. 16. Development drift secured by means of the ŁPKO support

The $\mathrm{tPro} / \mathrm{B}$ frame is a certain modification of the ŁPKO series. One of the ribs is supported by "half" of an ŁPKO frame, whereas the other - by a straight $\mathrm{V}$ section supported by a prop. The frame obtained in this way has an arching-rectangular shape [29]. Two types of these frames were designed in $2003-€$ Pro/A and $\measuredangle P r o / B$. The $€ P r o / B$ arching-rectangular frame is intended primarily for securing longwall development drifts and longwall closure drifts, where it finds excellent application during the equipping and development commencement of a longwall, as well as when finishing the extraction of the panel. These frames
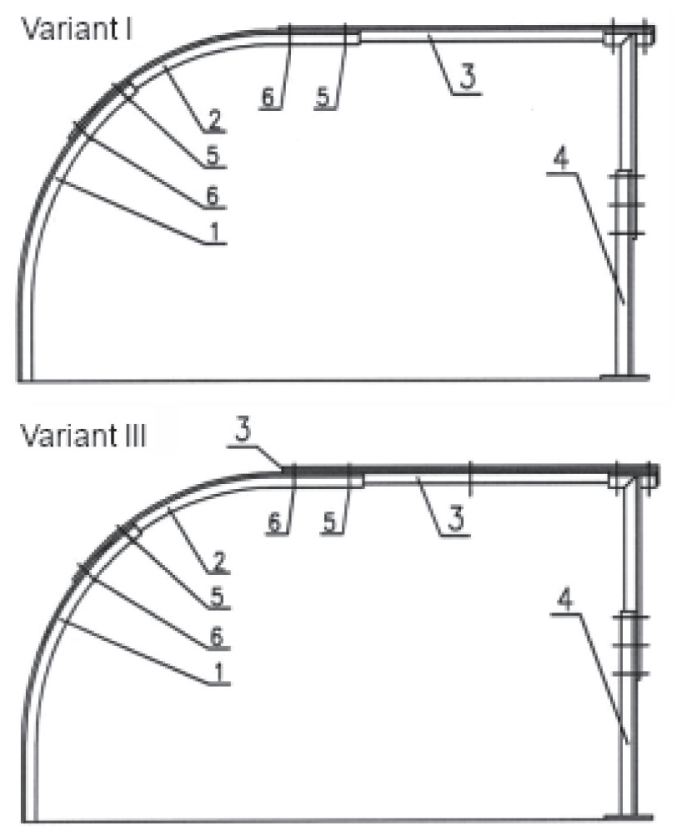

can be used in configuration with $\mathrm{KaPa}$ frames [30] to effectively secure gallery working junctions [31]. The $\mathrm{\iota Pro} / \mathrm{B}$ frame type is produced in four variants depicted in Figure 17. Variants I and III are versions with two-element top sections, whereas variants II and IV are characterised by single-element top sections. The series encompasses frames with widths of $3120-7900 \mathrm{~mm}$ and heights of $3200-5420 \mathrm{~mm}$. The shape of the frames leads to an excellent fitting of the powered support units, as depicted in Figure 18. Meanwhile Figures 19 and 20 present example applications of this support in a working.

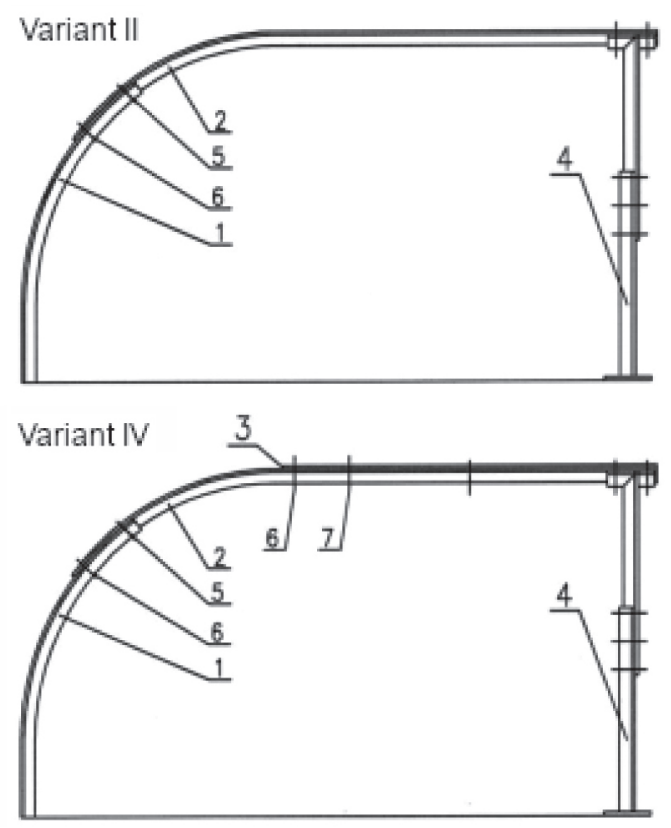

Fig. 17. ŁPro/B frame: 1 - side section, 2 - upper side section, 3 - straight top section, 4 - prop (supporting element), 5-7-shackles 


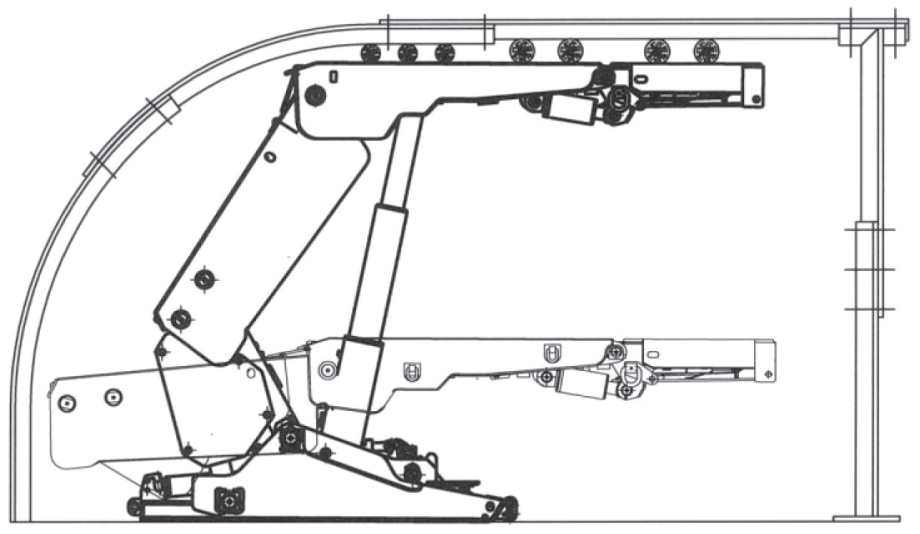

Fig. 18. ŁPro/B frame variant I with an installed powered support unit (unit before and after spragging)

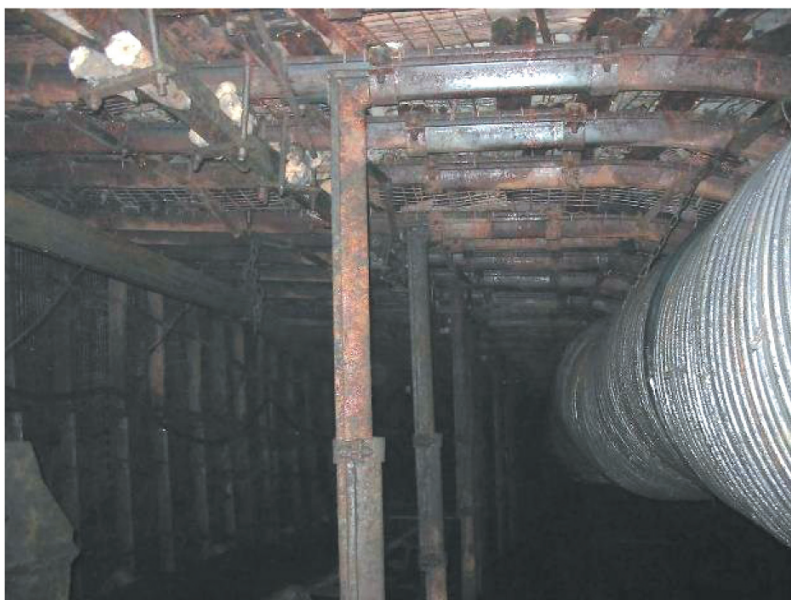

Fig. 19. Development drift secured by means of the $€$ Pro/B support

The arching-rectangular ŁPro/A frame type depicted in Figures 21 and 22 is a certain variation on the $\mathrm{EPro} / \mathrm{B}$ frame idea. Similarly to the $\mathrm{LPro} / \mathrm{B}$ type, this frame is intended primarily for securing longwall development drifts, longwall closure drifts and gallery working junctions. This frame type was designed

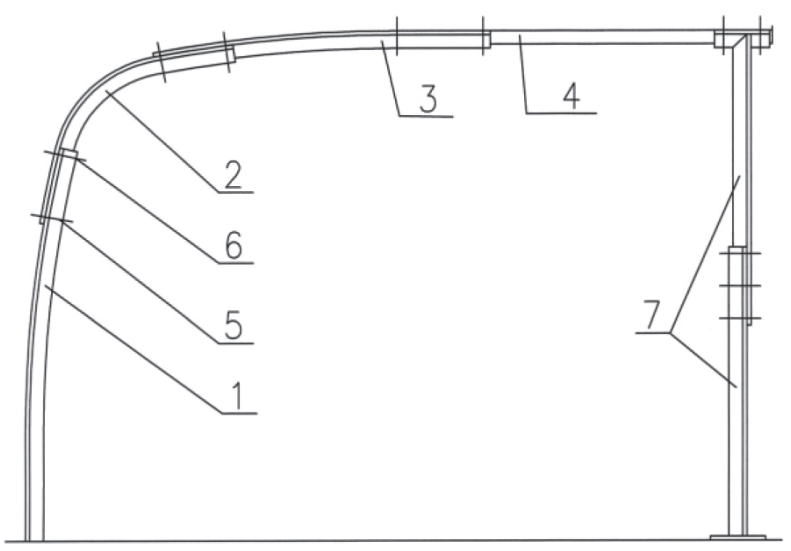

Fig. 21. ŁPro/A frame: 1 - side section, 2 - upper side section, 3 - top section, 4 - straight top section, 5, 6-shackles, 7-prop (supporting element)

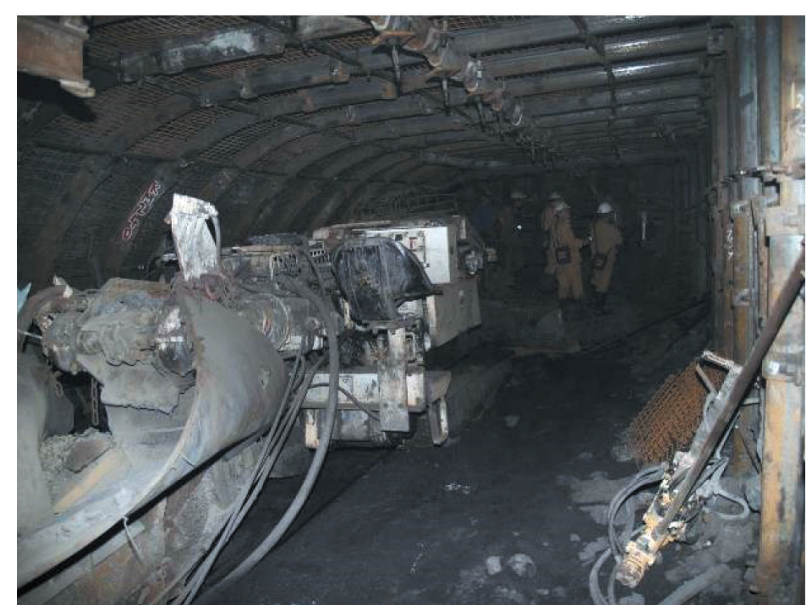

Fig. 20. Longwall closure drift secured by means of the $\mathrm{EPro/B}$ support

in 2003 for the needs of the LW "Bogdanka" mine. The design is based on the arching elements of the ŁPrP $\mathrm{K}$ frame, described in later parts of the article, while its dimensions are 5900-6900 mm in width and 3300-4400 mm in height. Example applications of the $\mathrm{EPro} / \mathrm{A}$ frame are presented in Figures 23 and 24.

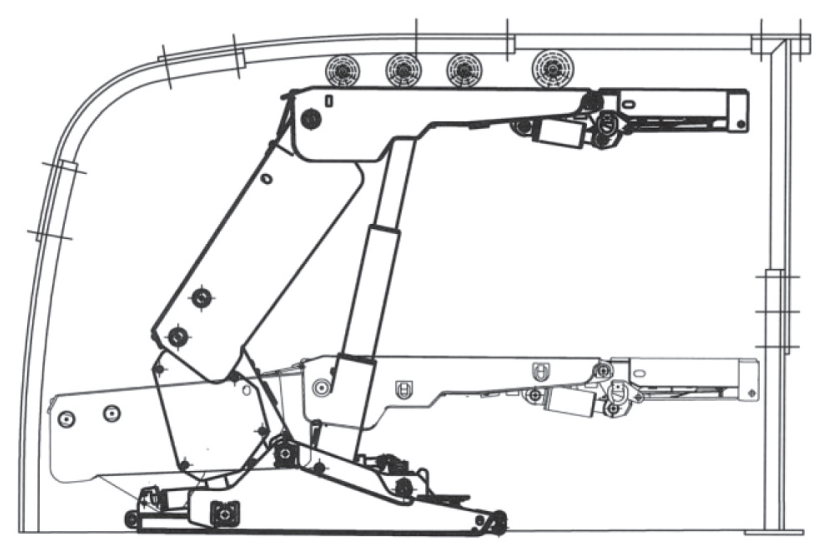

Fig. 22. ŁPro/A frame with an installed powered support unit (unit before and after spragging) 


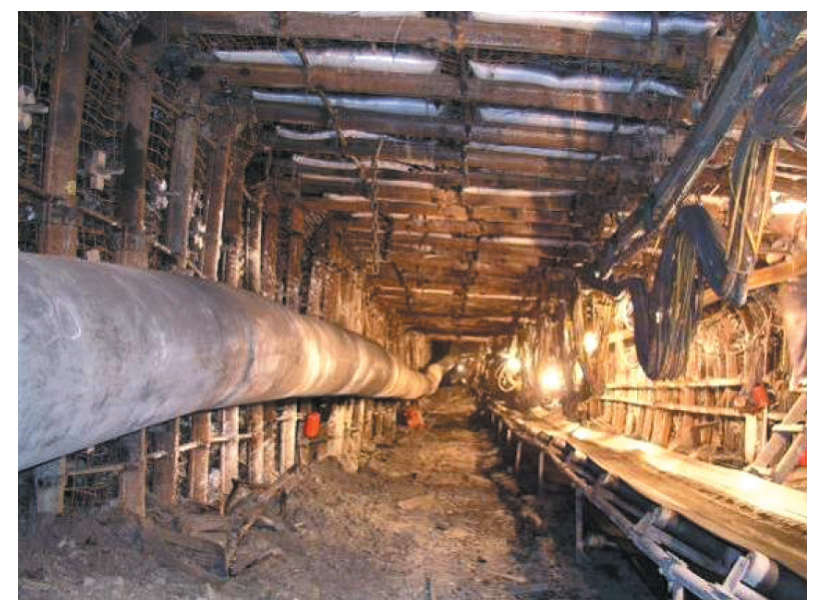

Fig. 23. Development drift secured by means of the ŁPro/A support

Observing the operation of support frames with straight top sections and identifying the deficiencies related to them resulted in the design of a new series of flat, arching top sections with low curvature. One of the first such designs was the EPS frame - its first version was produced in 1995. It is an arching-straight frame intended for development drift support. The frame design includes two variants: the first, with

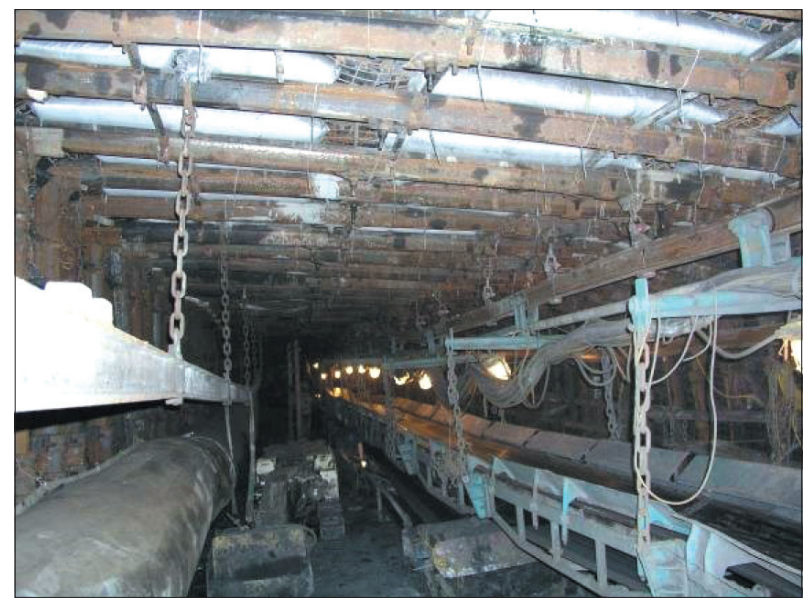

Fig. 24. Development drift secured by means of the $€$ Pro/A support

a single-element top section, is presented in Figure 25, whereas the second, with a two-element top section, is depicted in Figure 26. Given the coupling of the top section with the side section (short overlap), this frame is a rigid one. No yielding capability significantly limited the application of this frame, therefore the support was eventually replaced by the ŁPrP frame, which remains in use to this day.

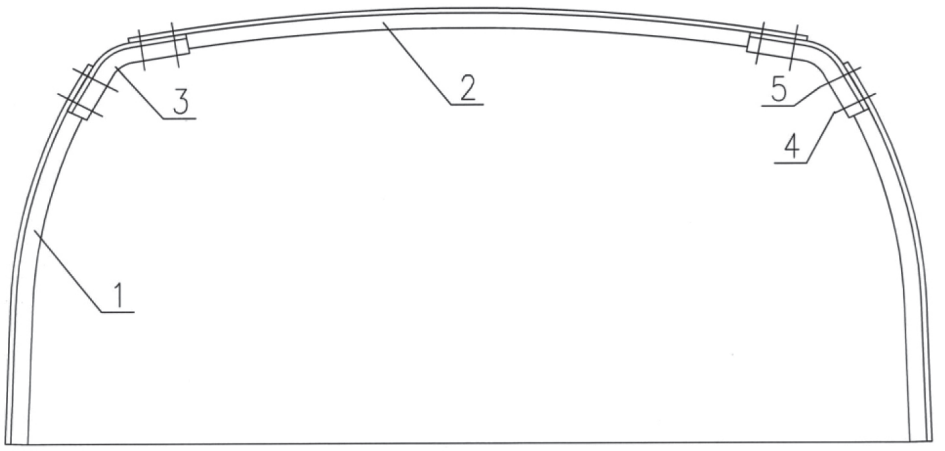

Fig. 25. ŁPS frame with a single-element top section: 1 - side section, 2 - top section, 3 - coupling, 4, 5 - shackles

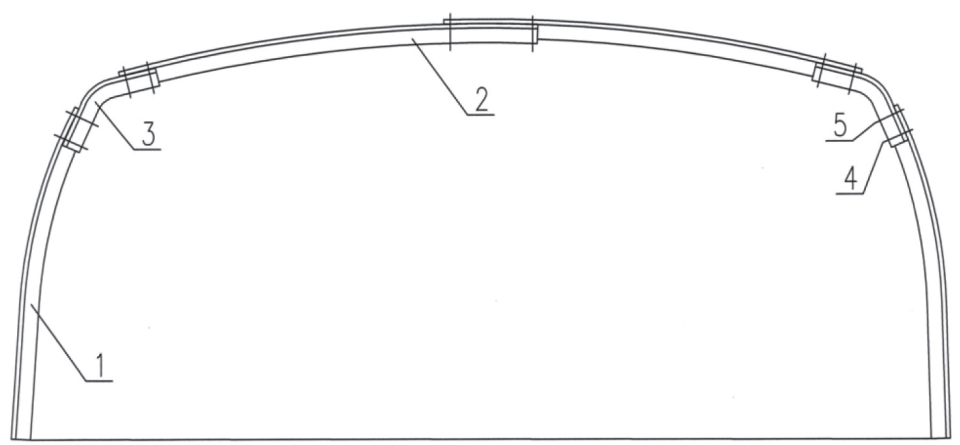

Fig. 26. ŁPS frame with a two-element top section: 1 - side section, 2 - top section, 3 - coupling, 4, 5 - shackles

The previously mentioned arching-straight ŁPrP frame is another series of frames made in accordance with the trend of designs dedicated to development drift support. It was designed in 1997 at the Central
Mining Institute. The yielding arching-straight ŁPrP frames constructed from $\mathrm{V}$ sections are primarily intended for securing longwall development drifts as well as other utility gallery workings with increased 
lateral dimensions. The flat frame geometry, compared to the standard $Ł P$ frame, limits overburden removal in low deposits, whereas the increased width makes it easier to equip the longwalls. The series includes three frame variants:

- four-element with a width of 4700-7650 mm, height of 2100-3000 mm (Figs. 27 and 28), and a triple-curved top section shaped for coupling with the side sections,

- five-element with a width of $3700-4200 \mathrm{~mm}$ and height of 2100-3000 mm (Figs. 29 and 30), a solid top section and corner elements for coupling the top with the side sections,

- six-element with a width of $4700-7650 \mathrm{~mm}$ and height of 2100-3000 mm (Figs. 31 and 32), a parted top section and corner elements for coupling the top with the side sections,

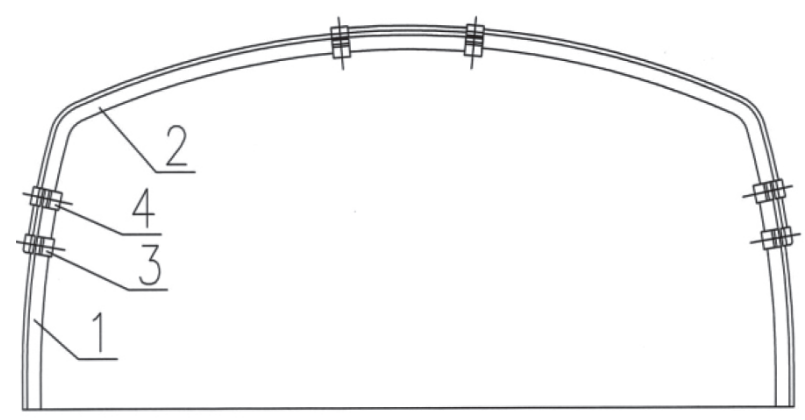

Fig. 27. Four-element $Ł P r P$ frame:

1 - side section, 2 - top section, 3, 4- shackles

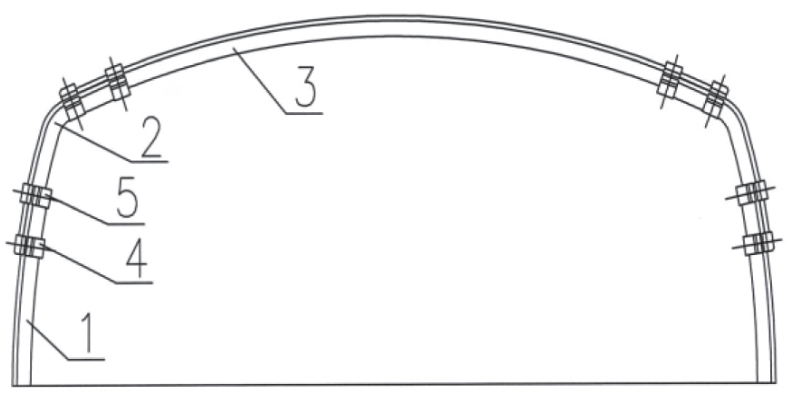

Fig. 29. Five-element $Ł P r P$ frame: 1 - side section I, 2 - side section II, 3 - top section, 4, 5 - shackles

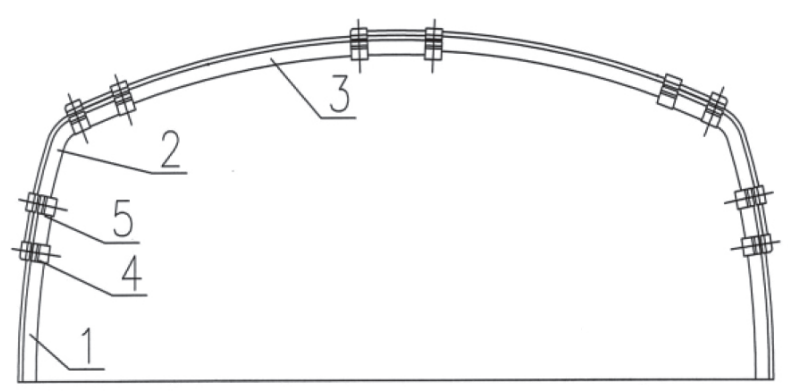

Fig. 31. Six-element $Ł P r P$ frame: 1 - side section I, 2 - side section II, 3 - top section, 4, 5 - shackles
The frames earned the appreciation of mining plant preparatory work departments, as evidenced by the example applications presented in Figures 33 and 34 [10].

In the year 2000, the $Ł P r P$ frame series was expanded with $\mathrm{EPrP}$ variants constructed from heavy V32 and V36 sections for use in the LW "Bogdanka" mine. The frames were designed in two variants, differing slightly in shape, and their designations referenced the names of their manufacturers at the time Huta Łabędy $€$ and Huta Katowice K. Additional sill pieces were designed as well, installed optionally should it be required. The frames were intended to secure workings with widths of 4800-6400 $\mathrm{mm}$ and heights of $3300-4400 \mathrm{~mm}$. Figures 35 and 36 present the $€ P r P ~ Ł$ frames, whereas Figures 37 and 38 - the ŁPrP K frames. Example applications of the support are depicted in Figures 39 to 44.

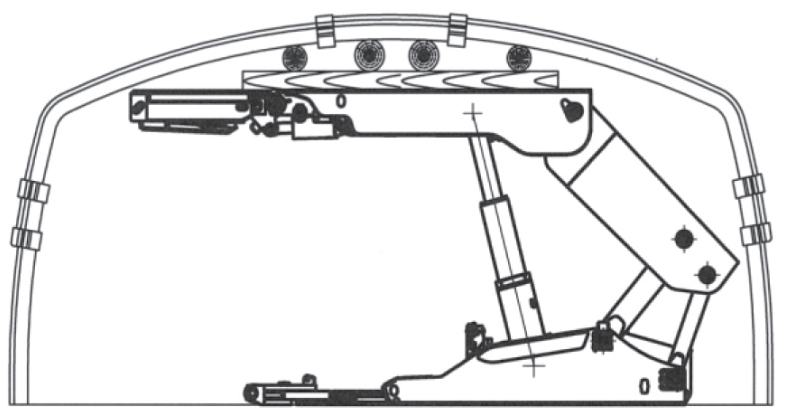

Fig. 28. Four-element ŁPrP frame with an installed powered support unit

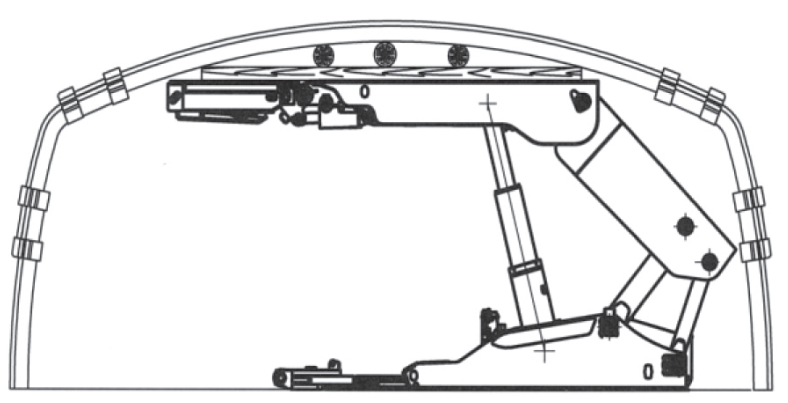

Fig. 30. Five-element $Ł P r P$ frame with an installed powered support unit

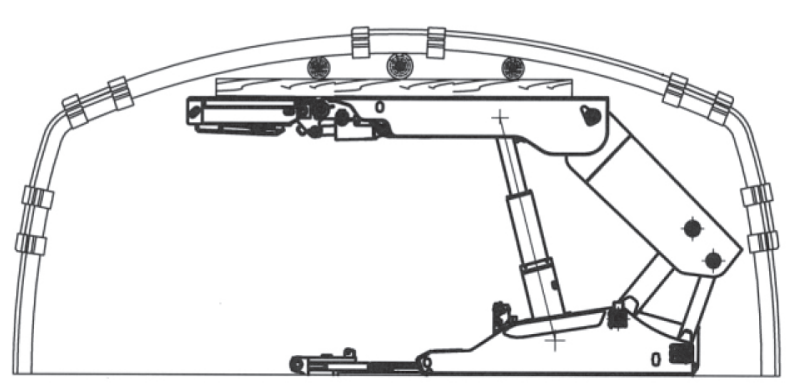

Fig. 32. Six-element $Ł P r P$ frame with an installed powered support unit 


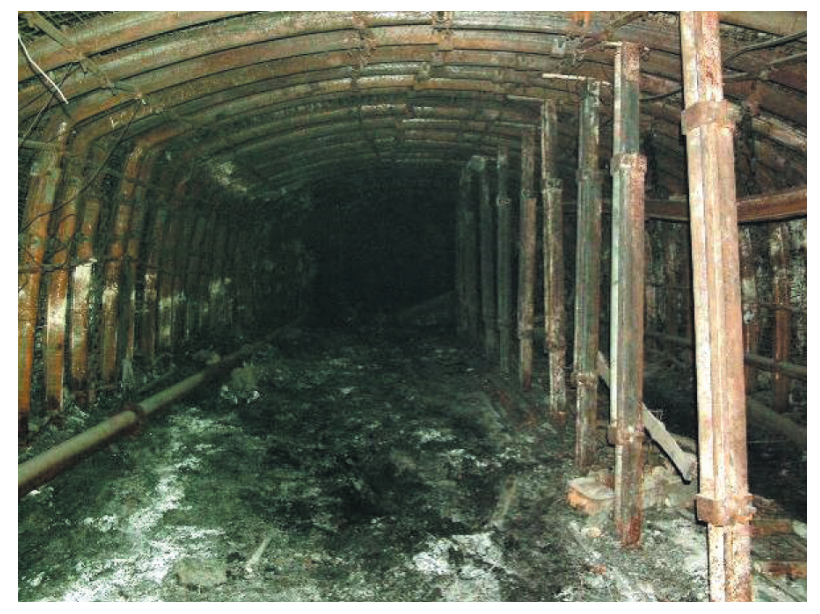

Fig. 33. Development drift secured with four-element ŁPrP frames

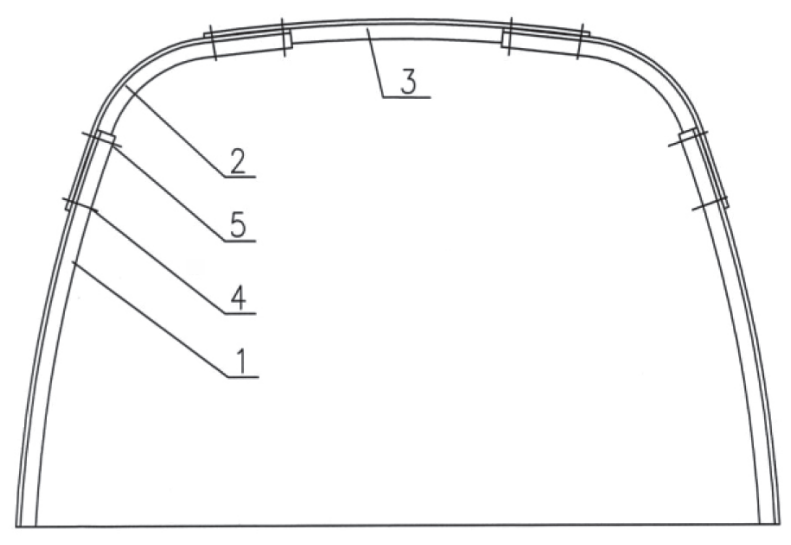

Fig. 35. ŁPrP frame variant $€: 1$ - side section I, 2 - side section II, 3 - top section, 4, 5 - shackles

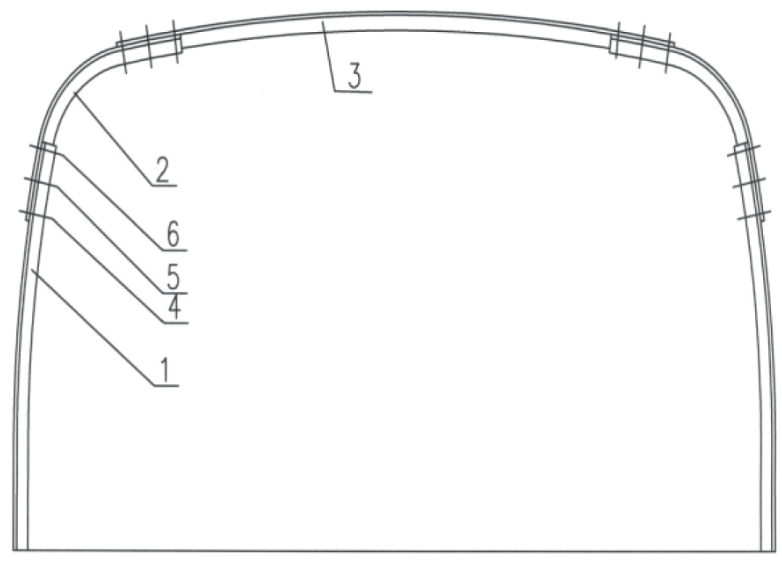

Fig. 37. ŁPrP frame variant $K$ : 1 - side section $I$, 2 - side section II, 3 - top section, 4-6-shackles

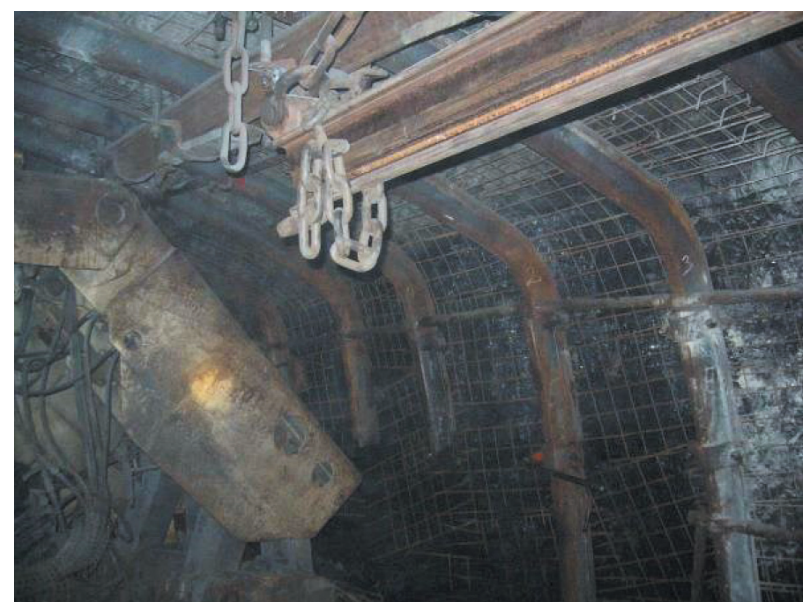

Fig. 34. Longwall equipment, development drift

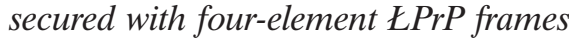

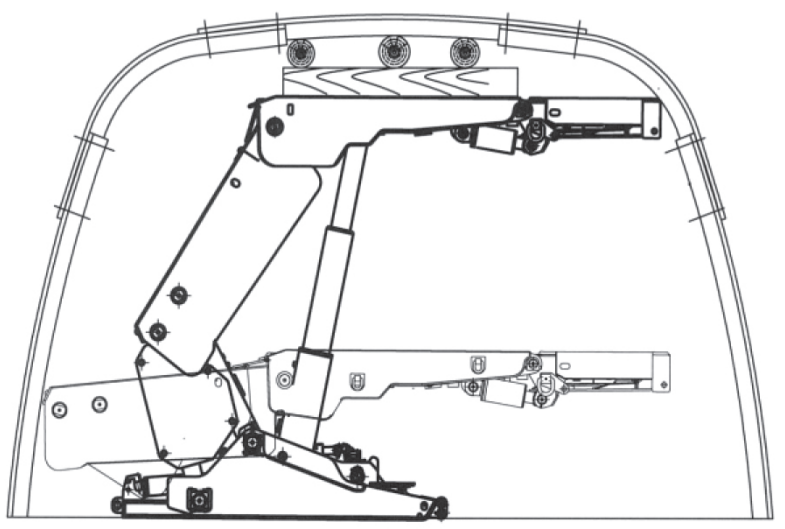

Fig. 36. $Ł P r P$ frame variant $€$ with an installed powered support unit (unit before and after spragging)

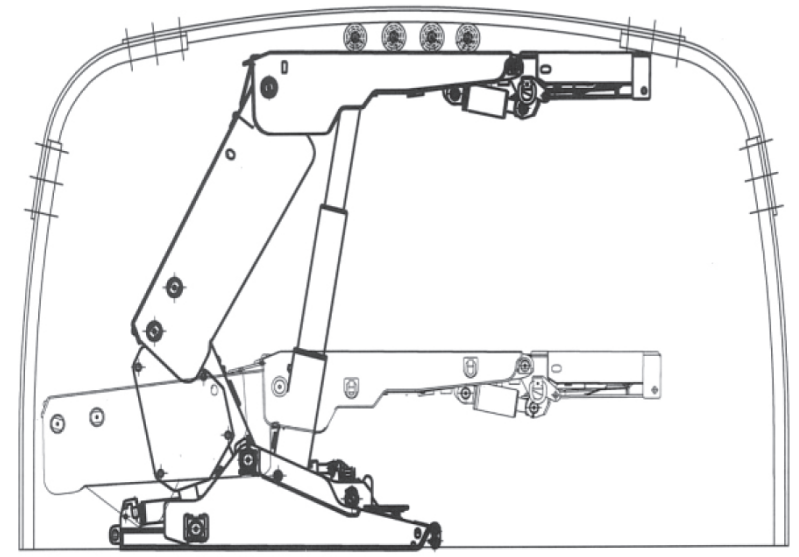

Fig. 38. $ヒ P r P$ frame variant $K$ with an installed powered support unit 


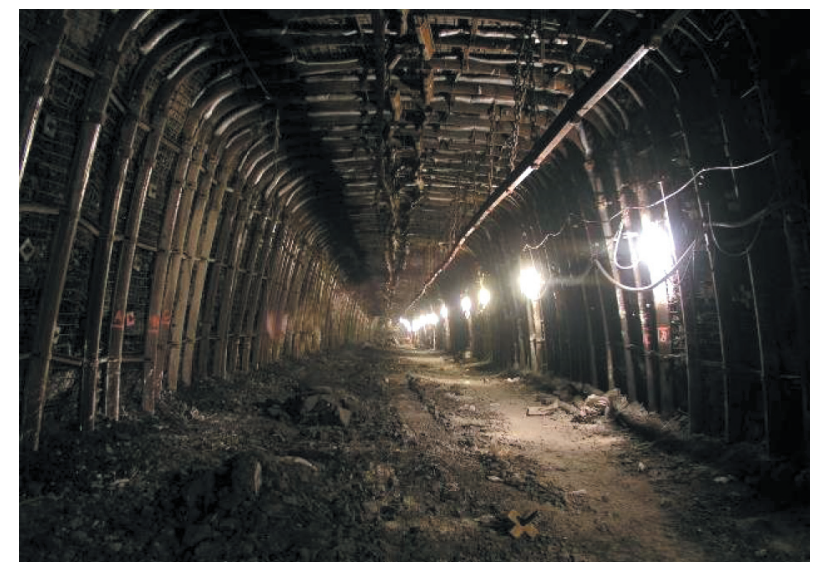

Fig. 39. Development drift secured by means of the $\mathrm{EPrP}$ variant $€$ support

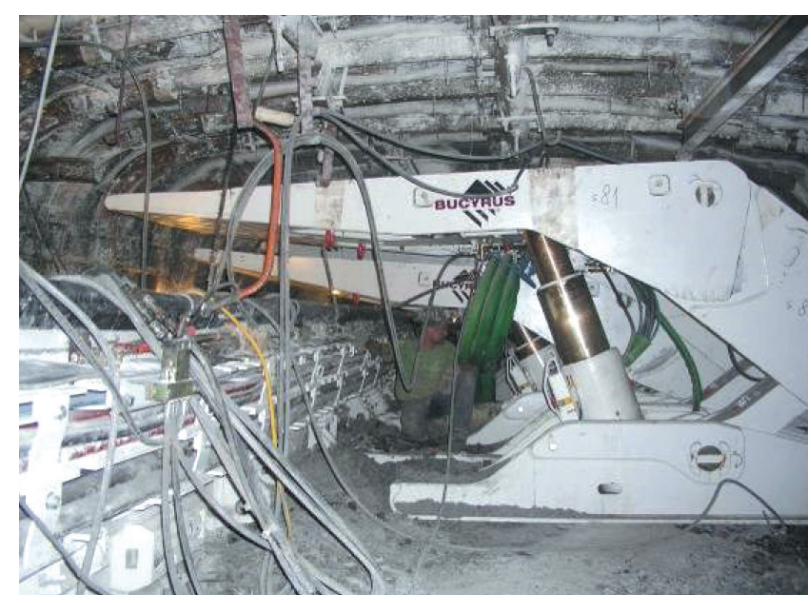

Fig. 41. Longwall equipment in a development drift secured by means of the ŁPrP variant K support

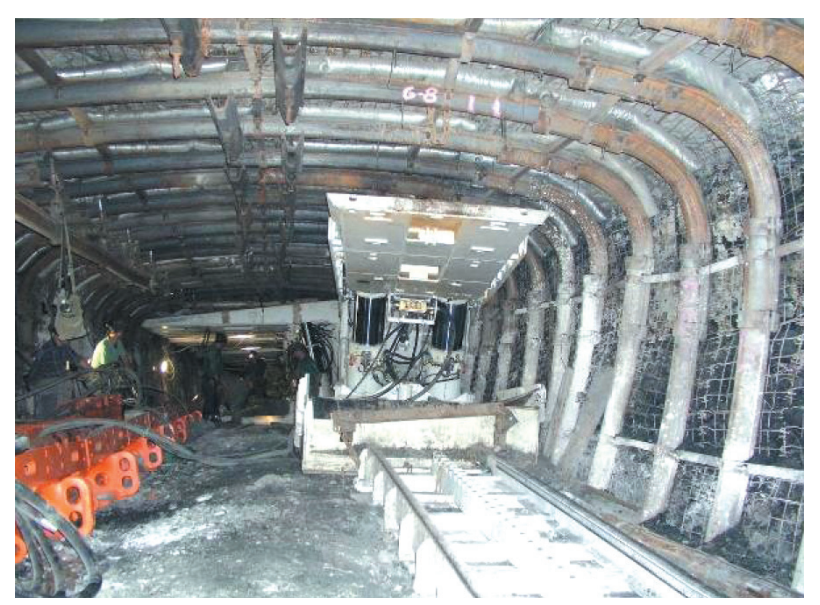

Fig. 43. Longwall equipment in a development drift secured by means of the $€ P r P$ variant $K$ support

The reinforced arching-straight $€ P r w$ frame depicted in Figures 45 and 46, constructed from V29, V32, V34 and V36 sections, is a certain modification and expansion of the series presented above. The support was designed for securing the development drifts of longwalls developed with hydraulic filling, which makes it

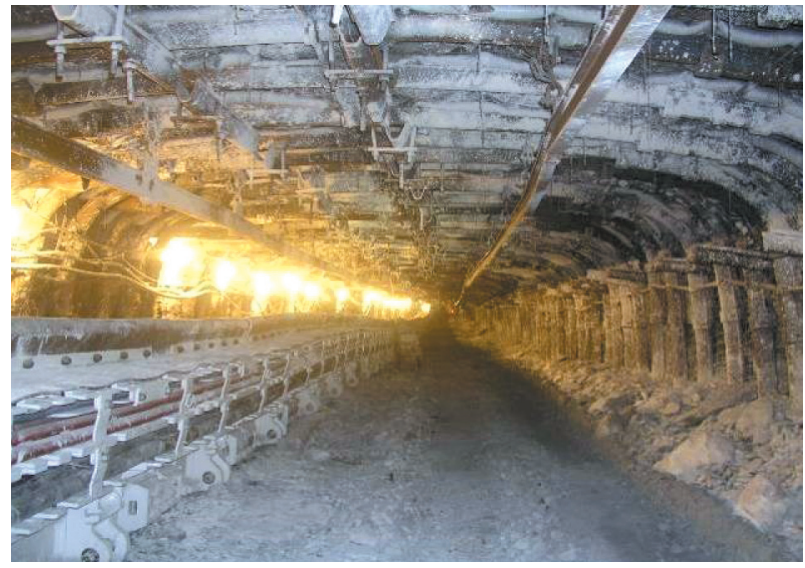

Fig. 40. Development drift secured by means of the $€ P r P$ variant $K$ support

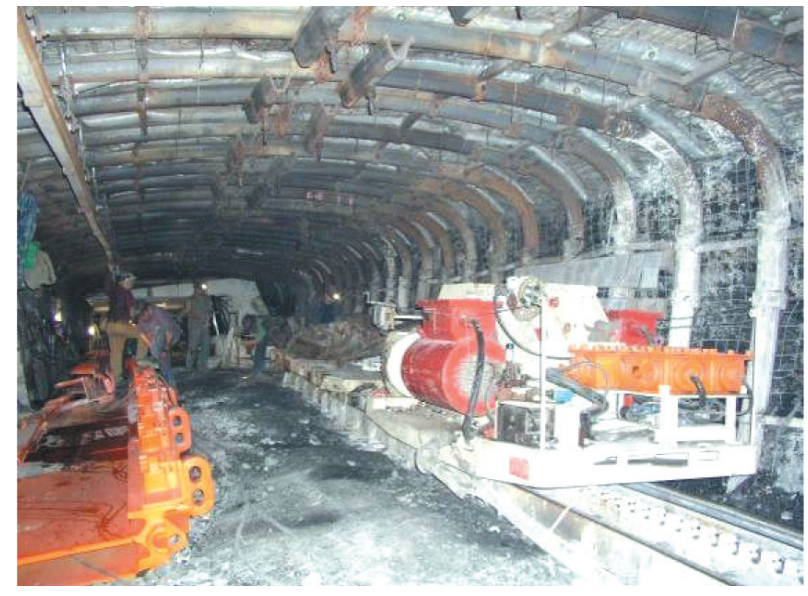

Fig. 42. Longwall equipment in a development drift secured by means of the $Ł P r P$ variant K support

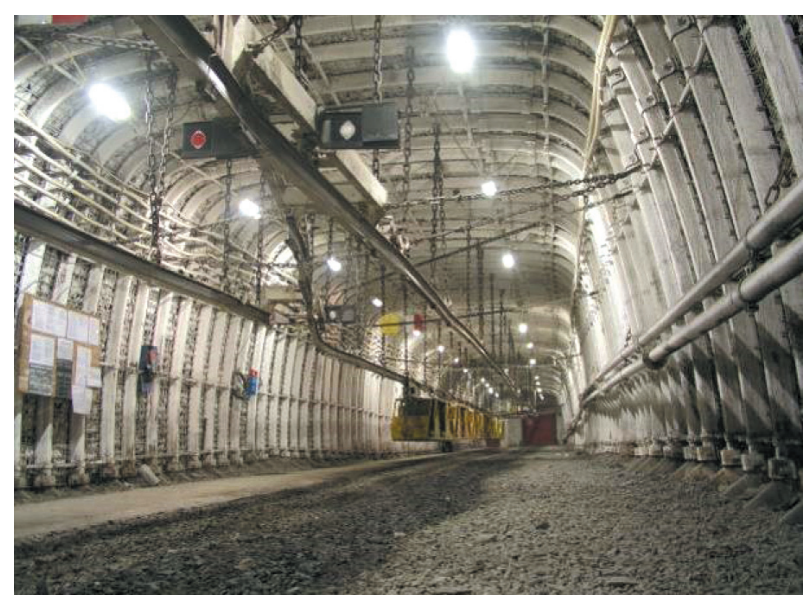

Fig. 44. Railway station constructed inside an $€ P r P$ variant $€$ support

possible to equip the longwall with support units of great sizes. This was the reason why the frame exhibited such a significant size for that time. Initially, the series included frames intended for workings with a maximum width of $7200 \mathrm{~mm}$ and height of $5000 \mathrm{~mm}$ and was the subject of broad consultations with the first 
user - the Wujek mine [32]. The current series underwent significant expansion with bigger frame sizes a few years ago. The high load-bearing parameters of these frames, at a great width and low top section curvature, were achieved by utilising a reinforcing top section constructed from a section intended for the construction of shackle clevises. Figures 47 and 48 [33] present example practical applications of the $Ł P r w$ frame.

At the same time, an attempt was made to combine a rectangular support with a (slightly flat) arching design. The result of this was the creation of the double

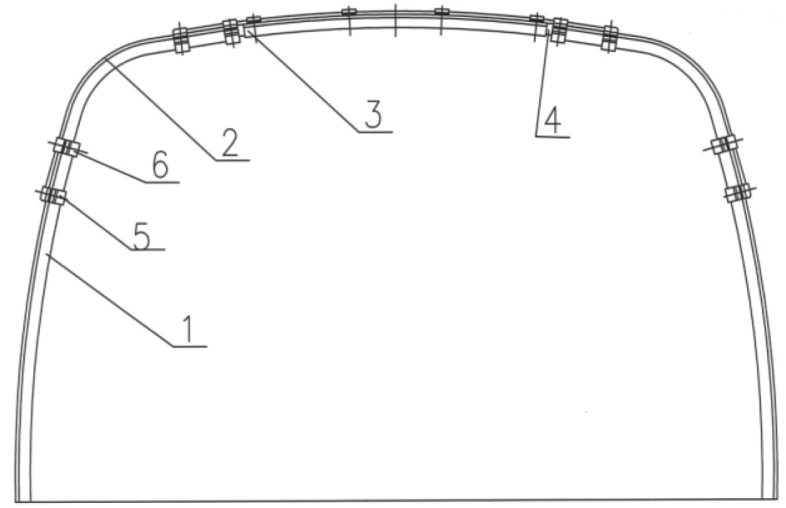

Fig. 45. ŁPrw frame: 1 - side section, 2 - upper side section, 3 - top section, 4 - reinforcing top section, 5, 6- shackles

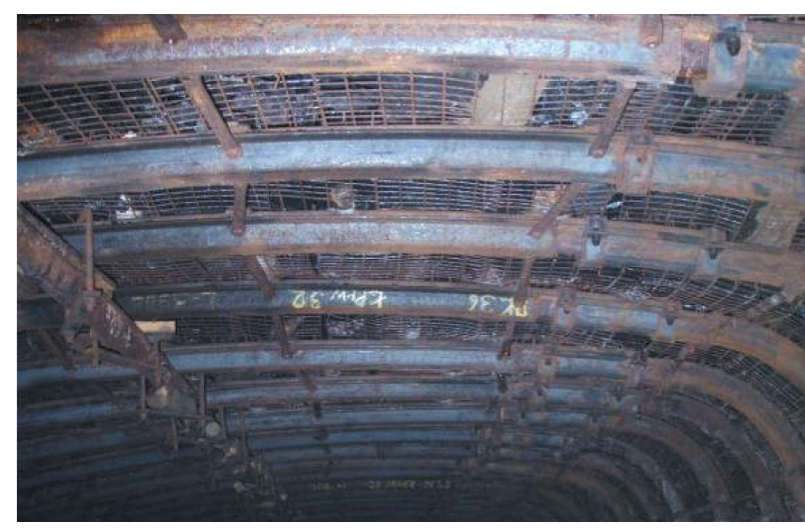

Fig. 47. Development drift secured by means of the EPrw support

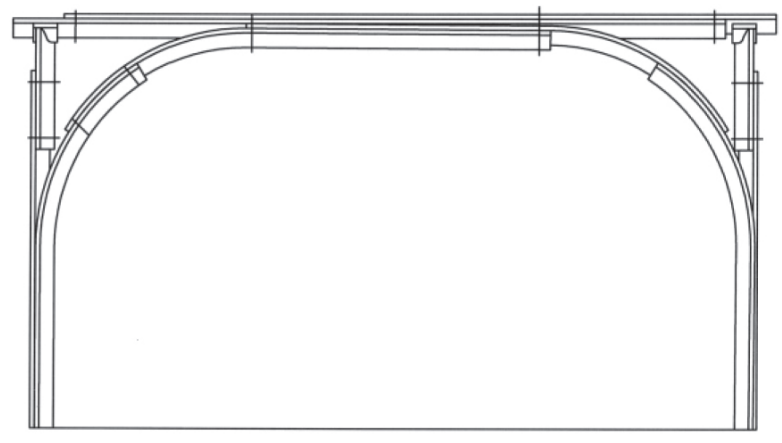

Fig. 49. KaPa frame arching-rectangular KaPa frame [30-35]. These frames were primarily intended for longwall development drifts characterised by great widths, driven under difficult geological and mining conditions, where top section bolting was impossible due to the low strength of the roof rock. Their structure is a "de facto" combination of the $\mathrm{EPKO}$ frame with a rectangular frame. The frame structure is presented in Figures 49 and 50. In combination with the $\mathrm{LPro}$ frames, this frame type also finds excellent application in securing the entries to workings at junctions [31].

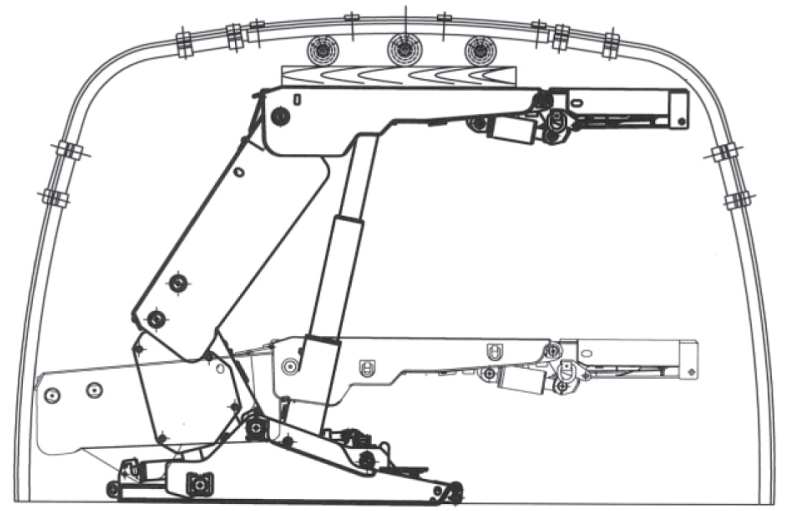

Fig. 46. ŁPrw frame with an installed powered support unit

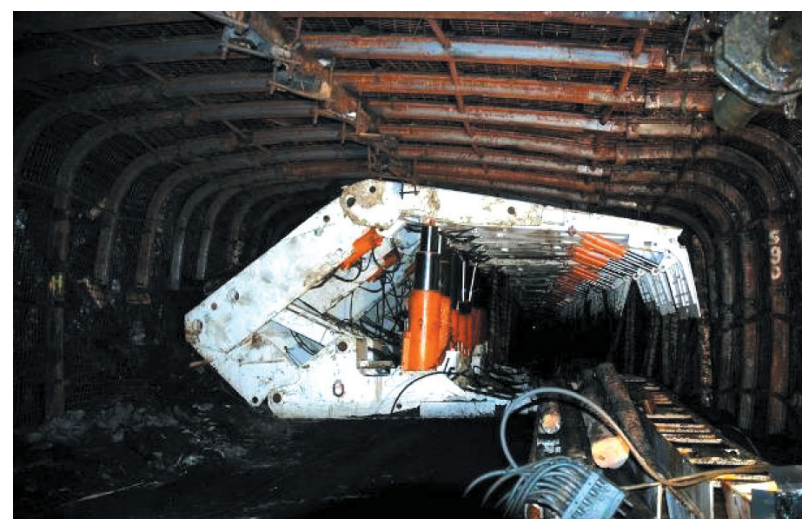

Fig. 48. Longwall equipment, development drift secured by means of the $E P r w$ support

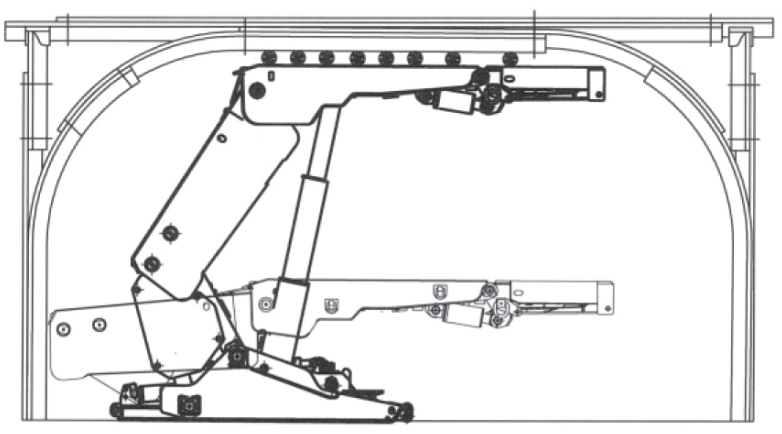

Fig. 50. KaPa frame with an installed powered support unit (unit before and after spragging) 
In 2014, a new universal series of yielding arch frames designated LPS was designed at the Central Mining Institute [36]. Although their identification refers to the earlier constructions, these frames are completely different from those presented previously. The frames are intended for securing all types of gallery workings in underground mining plants. Their versatility stems from the potential for free configuration using arching sections of 17 sizes. Because of their particular geometry, arching sections of different sizes can be combined, resulting in frames that are varied in both dimensions and shape. Therefore, the scope of application of these frames encompasses more than just development drifts. This made it possible to obtain a universal series of frames with maximum element unification.

The second generation of the EPS support frame was designed as a four-element arching frame constructed from V29, V32 and V36 sections. In the basic variant, the frame comprises four identical arching sections of the same size. Each of the sections exhibits two different curvatures, one of which is shared by the entire series. The principle for assembling the arches is the same for the entire series - the sections are cou-

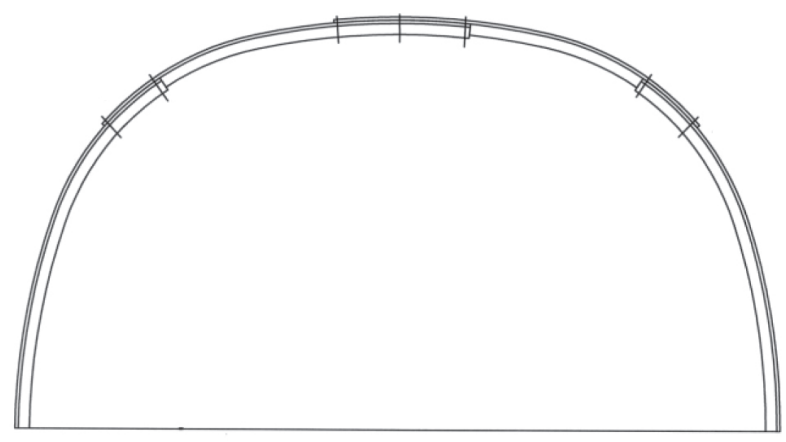

Fig. 51. Universal ŁPS II frame

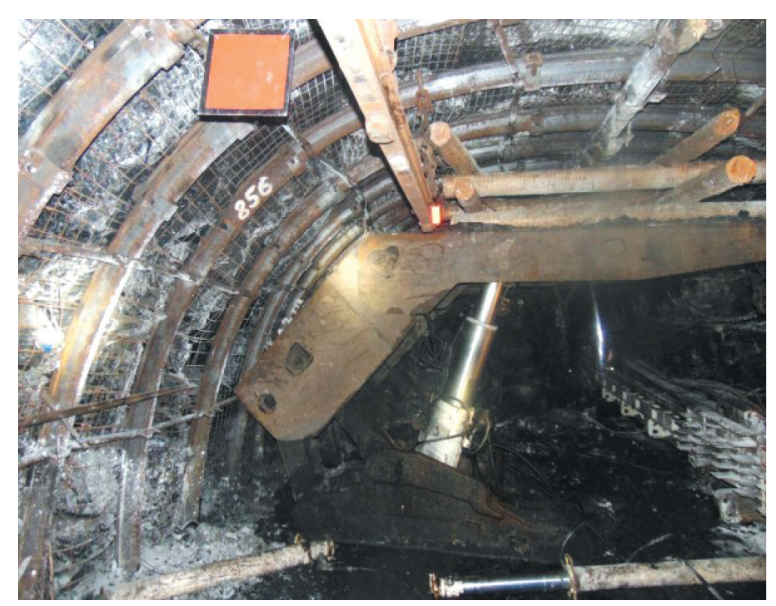

Fig. 53. Equipping a development drift driven in universal ŁPS II frames pled with one another at the ends that exhibit identical geometric parameters. The frame structure is presented in Figures 51 and 52 [8], whereas Figures 53 and 54 [37] present the equipping of a longwall. Currently, the basic series (four identical arching sections) encompasses 18 frames, whereas the combined series (two pairs of different-sized sections) makes it possible to obtain 306 additional frame sizes. The nominal size range for the entire series encompasses widths of $5400-8800 \mathrm{~mm}$ and heights of $2790-5200 \mathrm{~mm}$. The nominal arching sections make it possible to assemble 324 frames of different sizes, though the number of combinations increases once the possibilities of changing the side section lengths and the overlap arrangements are taken into consideration.

With such a great number of frame variants that can be constructed as part of a single series, it was necessary to develop specialist and accessible software for the computer-assisted design of these frames [38]. The main window of this software is presented in Figure 55.

In 2020, the second generation of the LPS frame series was expanded with asymmetrical variants, presented in Figures 56 and 57 [8].

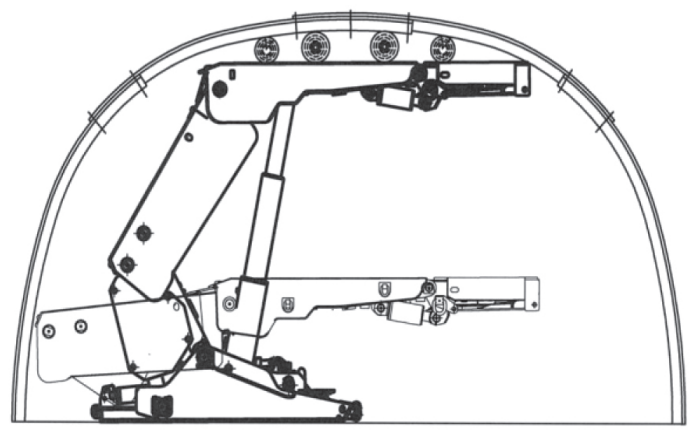

Fig. 52. Universal ŁPS II frame with an installed powered support unit

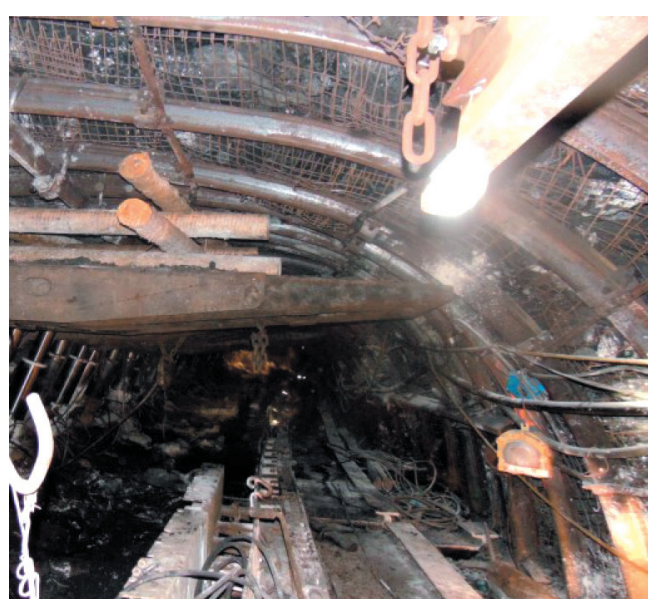

Fig. 54. Equipping a development drift driven in universal ŁPS II frames 


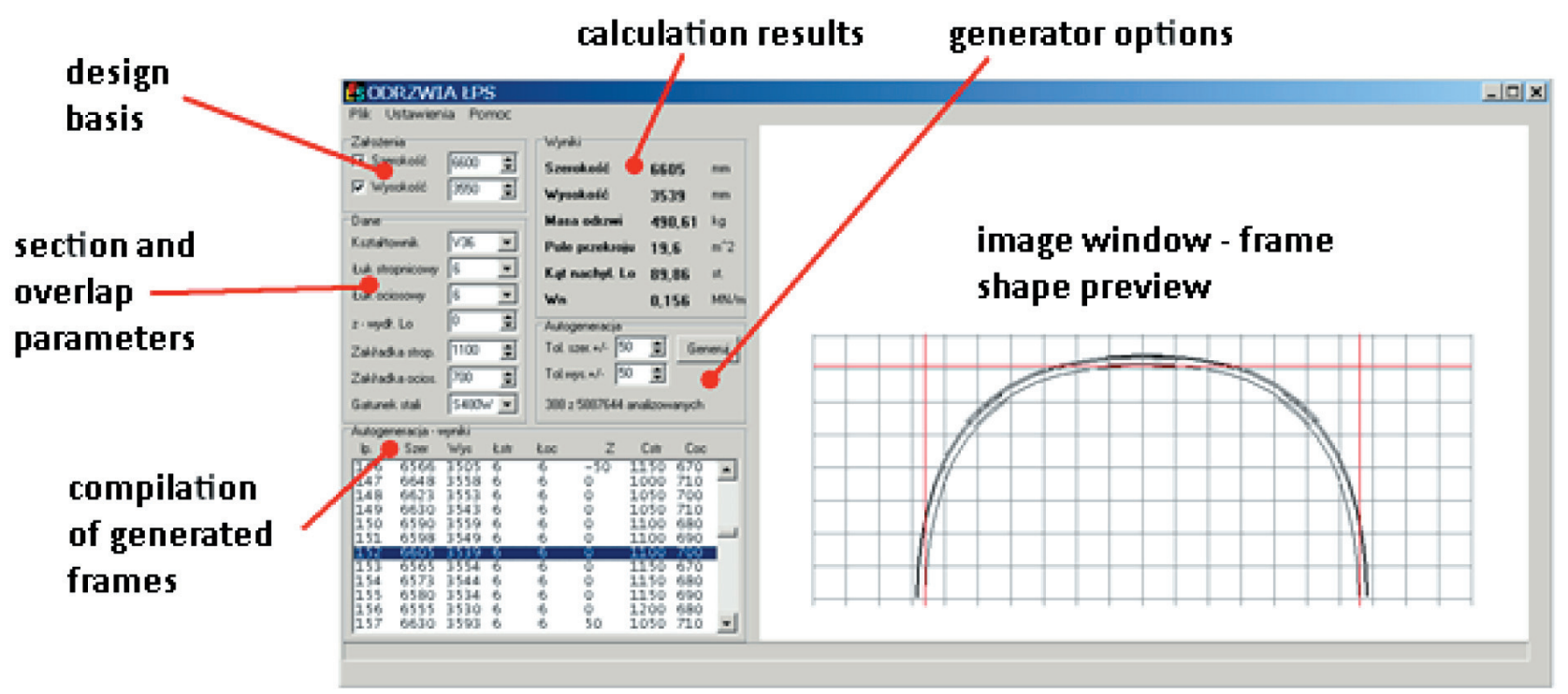

Fig. 55. Main window of the computer-assisted ŁPS II frame design software [23]

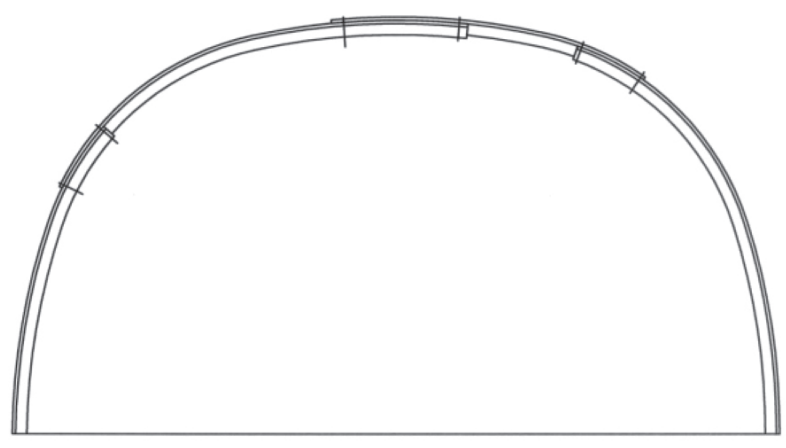

Fig. 56. Universal ŁPS II frame

in the asymmetrical version

\section{SUMMARY}

Numerous series of frames dedicated to securing longwall development drifts have been designed over the last forty years as a result of the trilateral cooperation of the Central Mining Institute, Huta Łabędy and hard coal mining plants. Many of them also include several structural versions, which offers the users, i.e. the mines, even up to several dozen frame set variants to choose from. The solutions factor in the diversity of the geological and mining conditions found in specific mines as well as the individual circumstances resulting from the employed mining technology and powered support systems.

Such a number of structural solutions makes it possible to select the optimal support for specific conditions - the required dimensions, the expected loads exerted by the rock mass, the longwall height - which translates into the safety and efficiency of the con-

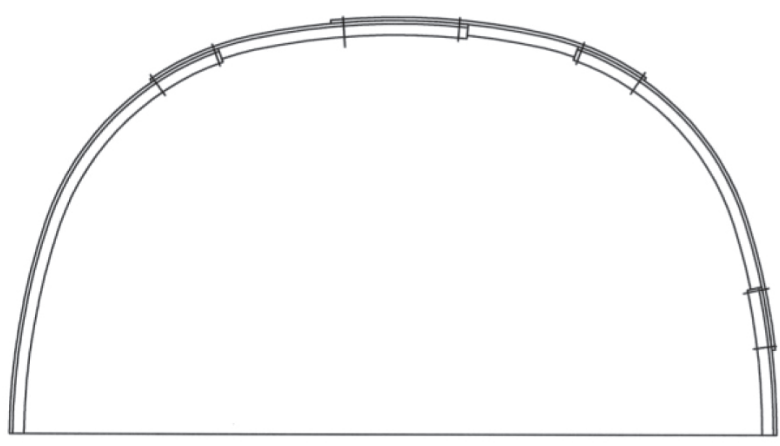

Fig. 57. Universal ŁPS II frame in the asymmetrical version with a parted side section

ducted work both when installing and spragging the powered support units and during the subsequent development of the longwall.

The designed solutions are an effect of many years of research and development work as well as data gathering regarding the operation of arch support systems and their interaction with the powered support.

At the same time, the continued development of this support type should be expected, particularly in the context of increasing mining depth, deteriorating geological and mining conditions, and the consequent increase in loads. Furthermore, the increase in the lateral dimensions of both the longwall development drifts and the support systems is very likely, as a result of the growing concentration of output and the increasing dimensions of powered support units and the entire longwall networks. This will most likely involve the increased contribution of rock bolts in 
development drift support (mixed arch and bolt support, frame rock bolting), especially due to the necessity of reducing the support assembly costs while retaining a high level of safety [39, 40]. Another direction for the development of these supports, which can be conducted simultaneously, may be their further adaptation to the mining conditions - the longwall height or the type and size of the powered support units - accomplished through the appropriate selection of the arching section lengths and the optimal sliding joint placement. This will increase the efficiency of the powered support unit removal from the drift and the development of the longwall itself.

\section{References}

[1] PN-H-84042:2009: Stale mikrostopowe na ksztattowniki $i$ akcesoria górnicze.

[2] ZN/TT/2012/1: Stal mikrostopowa S550W na kształtowniki $i$ akcesoria górnicze.

[3] PN-93-G-15000-02: Obudowa chodników odrzwiami podatnymi z kształtowników korytkowych. Odrzwia tukowe podatne ŁP, z kształtowników typu V, typoszereg A. Wymiary.

[4] PN-93-G-15000-03: Obudowa chodników odrzwiami podatnymi z kształtowników korytkowych. Odrzwia tukowe podatne ŁP, z kształtowników typu V, typoszereg A. Łuki.

[5] PN-G-15021:2019-05: Obudowa wyrobisk górniczych. Odrzwia podatne z kształtowników korytkowych. Odrzwia tukowe podatne $Ł P z$ ksztattowników typu $V$.

[6] Rotkegel M.: Contribution to the problem of frame clear interval determination of rectangular steel support, "Archives of Mining Sciences" 2001, 46, 3: 267-289.

[7] Rotkegel M.: Siły wewnętrzne i reakcje podporowe $w$ elementach obudowy prostokątnej, "Kwartalnik Prace Naukowe Głównego Instytutu Górnictwa” 2009, 1: 51-66.

[8] Katalog Wyrobów dla Górnictwa, Huta Łabędy 2019.

[9] Katalog obudów rozcinek ścianowych "Projekt" - Komisja ds. Obudów Zmechanizowanych i Kierowania Stropem w Podziemnych Zakładach Górniczych przy Centrum Mechanizacji Górnictwa KOMAG, Gliwice 1997.

[10] Bobek R., Śledź T., Ratajczak A., Mąka B., Głuch P.: Doświadczenia ze stosowania obudów podporowych i podporowokotwiowych $w$ przecinkach ścianowych $w$ kopalni "Knurów-Szczygłowice” Ruch Knurów, Warsztaty Górnicze 2012 z cyklu "Zagrożenia naturalne w górnictwie".

[11] Prusek S., Rotkegel M., Bock S.: Design and control of working support in Polish coal mines based on three-dimensional numerical modeling, $28^{\text {th }}$ International Conference on Ground Control in Mining, Morgantown, USA, 2009.

[12] Prusek S., Rotkegel M., Tor A.: Przebieg kompleksowego procesu projektowania nowej konstrukcji obudowy wyrobisk korytarzowych, Szkoła Eksploatacji Podziemnej, Kraków 2008: 333-351.

[13] Chmielewski T., Nowak H.: Mechanika budowli. Metoda przemieszczeń. Metoda Crossa. Metoda elementów skończonych, Wydawnictwa Naukowo-Techniczne, Warszawa 1996.

[14] Rakowski G., Kacprzyk Z.: Metoda elementów skończonych $w$ mechanice konstrukcji, Oficyna Wydawnicza Politechniki Warszawskiej, Warszawa 1993.
[15] Rusiński E.: Metoda elementów skończonych. System COSMOS/M, Wydawnictwa Komunikacji i Łączności, Warszawa 1994.

[16] COSMOS/M - User's Guide, Structural Research \& Analysis Corp. Los Angeles, USA 1999.

[17] PN-H-93441-3:2004: Ksztattowniki stalowe walcowane na gorąco dla górnictwa. Kształtowniki typu $V$. Wymiary.

[18] PN-H-93441-1:2013-12: Ksztattowniki stalowe walcowane na goraco dla górnictwa. Ogólne wymagania i badania.

[19] Brodny J.: Determining the working characteristic of a froction joint in a yieldning support, "Archives of Mining Sciences" 2010, 55, 4: 733-746.

[20] Brodny J.: Tests of Friction Joints in Mining Yieldning Supports Under Dynamic Load, "Archives of Mining Sciences" 2011, 56, 2: 303-318.

[21] Pytlik A.: Experimental studies of static and dynamic steel arch support load capacity and sliding joint temperature parameters during yielding, "Archives of Mining Sciences" 2020, 65, 3: 469-491.

[22] PN-G-15000-05:1992: Obudowa chodników odrzwiami podatnymi z kształtowników korytkowych. Odrzwia tukowe otwarte. Badania stanowiskowe.

[23] PN-G-15022:2018: Obudowa wyrobisk górniczych. Odrzwia podatne z kształtowników korytkowych. Wymagania wytrzymałościowe i badania.

[24] Rotkegel M., Prusek S., Grodzicki M.: Odrzwia obudowy chodnikowej ze stali nowej generacji. Nowa konstrukcja odrzwi $i$ wyniki przeprowadzonych badań, Szkoła Eksploatacji Podziemnej, Kraków 2012.

[25] Kuziak R., Żak A., Woźniak D., Rotkegel M., Grodzicki M., Nawrot J.: Odrzwia obudowy chodnikowej ze stali II generacji, "Prace Instytutu Metalurgii Żelaza" 2012, 4: 4-17.

[26] Rotkegel M., Prusek S., Kuziak R., Grodzicki M.: Obudowa $Ł P w$ ze stali o podwyższonych parametrach mechanicznych II generacji, Szkoła Eksploatacji Podziemnej, Kraków 2013.

[27] Rotkegel M.: Odrzwia obudowy $Ł P w$ - projektowanie $i$ wyniki badań, "Journal of Sustainable Mining" 2013, 1, 12: 34-40.

[28] Bobek R., Śledź T., Ratajczak A. i Głuch P.: Porównanie obudowy ŁPKO $i$ ŁPSp w rozcince ściany wydobywczej $w$ trudnych warunkach geologiczno-górniczych $w$ kopalni Knurów-Szczygłowice, "Budownictwo Górnicze i Tunelowe" 2013, 4: $1-9$.

[29] Rotkegel M.: The conditions for proper operation of the archrectangular support, "Archives of Mining Science" 2019, 64, 1: 213-222.

[30] Skrzyński K., Rotkegel M.: Obudowa podwójna dla rozcinek ścianowych wykonywanych $w$ trudnych warunkach górniczo-geologicznych, Prace Naukowe GIG, Seria "Konferencje", Nr 31, Katowice 1999.

[31] Rotkegel M., Bock S., Witek M., Adamiec P.: Sposób zabezpieczenia połaczenia wyrobisk korytarzowych $w$ warunkach strefy uskokowej, in: Nowe spojrzenie na wybrane zagrożenia naturalne w kopalniach, red. S. Prusek, J. Cygankiewicz, GIG, Katowice 2012: 5-14.

[32] Kowalski E., Rotkegel M., Kościerzyński Z., Wójcik D.: Obudowa tukowo-prosta przeznaczona głównie do zabezpieczenia rozcinek ścian z podsadzka hydrauliczna, "Przegląd Górniczy” 2003, 2: 13-18.

[33] Moszko M.: Stosowanie obudów specjalnych do wykonywania rozcinek ścianowych $w$ kopalni "Ziemowit", Konferencja Techniczno-Naukowa Huty Łabędy, 2009 [unpublished].

[34] Skrzyński K., Rotkegel M.: Obudowa kombinowana prosto-tukowa jako skuteczne zabezpieczenie rozcinek ścianowych, Szkoła Eksploatacji Podziemnej, Kraków - Szczyrk 2000. 
[35] Kowalski E., Rotkegel M., Rułka K., Skrzyński K.: Obudowy odrzwiowe proste i tukowo-proste, in: Stalowe obudowy odrzwiowe. Nowe rozwiazania konstrukcyjne $i$ metody projektowania, red. K. Rułka, Główny Instytut Górnictwa, Katowice 2006.

[36] Rotkegel M.: Nowy typoszereg odrzwi tukowo-prostych, "Wiadomości Górnicze" 2016, 11: 604-611.

[37] Łaskawiec Ł., Siudyła W., Caban P.: Efekty techniczno-ekonomiczne z zastosowania uniwersalnych odrzwi ŁPS $w$ warunkach KWK "Bobrek-Piekary", "Budownictwo Górnicze i Tunelowe" 2018, 1: 28-34.

[38] Rotkegel M.: Program komputerowy wspomagający dobór obudowy typu ŁPS, "Wiadomości Górnicze" 2017, 1: 8-12.

[39] Pytlik A.: Comparative bench testing of steel arch support systems with and without rock bolt reinforcements, "Archives of Mining Sciences" 2019, 64, 4: 747-764.

[40] Pytlik A.: Tests of steel arch and rock bolt support resistance to static and dynamic loading induced by suspended monorail transportation, "Studia Geotechnica et Mechanica" 2019, 41, 2: 81-92.
PIOTR CABAN, Eng.

Huta Łabędy S.A.

ul. Anny Jagiellonki 45, 44-109 Gliwice, Poland pcaban@hutalab.com.pl

KAZIMIERZ STOIŃSKI, prof.

MAREK ROTKEGEL, prof. SYLWESTER RAJWA, Ph.D., Eng. ADAM GNATOWSKI

KRZYSZTOF PACZEŚNIOWSKI, Ph.D., Eng. Gtówny Instytut Górnictwa (The Central Mining Institute) pl. Gwarków 1, 40-166 Katowice, Poland \{k.stoinski; mrotkegel; srajwa; agnatowski; kpaczesniowski\}@gig.eu

(C) 2020 Authors. This is an open access publication, which can be used, distributed and reproduced in any medium according to the Creative Commons CC-BY 4.0 License. 
PIOTR CABAN

KAZIMIERZ STOIŃSKI

MAREK ROTKEGEL

SYLWESTER RAJWA

ADAM GNATOWSKI

KRZYSZTOF PACZEŚNIOWSKI

\title{
Rozwój konstrukcji stalowych odrzwi do rozcinek ścianowych
}

\begin{abstract}
Artykut przedstawia rozwój konstrukcji obudów stalowych dla górnictwa, produkowanych przez Hute Łabędy S.A. z przeznaczeniem do zabezpieczania wyrobisk korytarzowych, a szczególnie rozcinek ścianowych. Na przestrzeni ostatnich dekad obudowa rozcinek rozruchowych ewoluowała między innymi pod względem ksztattu. Stosowane początkowo odrzwia prostokatne i typowe odrzwia ŁP z poszerzeniami zostaty zastapione przez odrzwia spłaszczone na bazie tuków ŁP (ŁPKO), a następnie przez specjalne odrzwia dostosowane ksztattem do sekcji obudowy zmechanizowanej. Uzyskano w ten sposób obrys odrzwi pośredni, będący kompromisem pomiędzy prostokątnym (korzystnym $z$ uwagi na zbrojenie $i$ uruchomienie ściany), a tukowym (korzystnym $z$ uwagi na wysokie parametry podpornościowe).
\end{abstract}

Słowa kluczowe: odrzwia, obudowa chodnikowa, rozcinka ścianowa

\section{WSTĘP}

W początkowym okresie działalności górniczych przedsiębiorstw wydobywających węgiel metodami podziemnymi stosowana technika była w niewielkim stopniu zmechanizowana. Eksploatowane były pokłady płytko zalegające od $200 \mathrm{~m}$ do $350 \mathrm{~m}$. Wraz z postępem technicznym sięgano po coraz głębiej zalegające złoża, których efektywna eksploatacja wymagała zastosowania zawansowanej technologii i techniki, między innymi urabiania kombajnów ścianowych. Stosowana eksploatacja metodą ścianową wymaga wykonania określonego układu chodników przygotowawczych, między innymi tzw. rozcinek ścianowych, zwanych też rozruchowymi. Jest to specyficzna grupa krótkotrwałych wielkogabarytowych wyrobisk korytarzowych, charakteryzujących się znaczną szerokością i wysokością dostosowaną do pokładu przeznaczonego do eksploatacji. Rozcinki ścianowe drążone są w celu zainstalowania zmechanizowanej obudowy ścianowej i niezbędnych urządzeń towarzyszących, umożliwiających rozruch ściany i eksploatację pokładu węgla. W polskich kopalniach węgla kamiennego w ostatnim czasie drąży się około 60-70 rozcinek ścianowych rocznie. $\mathrm{Z}$ uwzględnieniem średniej długości ściany daje to około $13 \mathrm{~km}$ wyrobisk, co przy założeniu rozstawu $0,75 \mathrm{~m}$ wymaga zastosowania odrzwi o wadze blisko 8 tysięcy ton. Zatem w skali globalnej stanowi to sporą ilość obudowy.

Celem artykułu jest przedstawienie całego spektrum konstrukcji odrzwi produkowanych przez ostatnie 30 lat w Hucie Łabędy, przeznaczonych do zabezpieczania rozcinek rozruchowych ścian. Przedstawione rozwiązania konstrukcyjne odrzwi pozwalają na zabezpieczenie rozcinek rozruchowych z uwzględnieniem gabarytów wszystkich stosowanych w kopalniach węgla kamiennego obudów zmechanizowanych. Zaprezentowane konstrukcje zostały opracowane w Głównym Instytucie Górnictwa we współpracy z Hutą Łabędy i kopalniami węgla kamiennego, wśród których można 
wyróżnić KWK Ziemowit, KWK Wesoła, LW Bogdanka, KWK Bobrek, KWK Wujek, KWK Pniówek, KWK Zofiówka oraz nieistniejące już kopalnie Katowice i Kleofas. Kopalnie wniosły duży wkład w zakresie weryfikacji odrzwi obudów i ich walorów użytkowych, co było podstawą do pewnych korekt i doprecyzowania szczegółów konstrukcyjnych w Głównym Instytucie Górnictwa. Taka współpraca tych trzech środowisk w ramach wdrażania nowych rozwiązań odrzwi pozwala połączyć ze sobą doświadczenie GIG w projektowaniu i badaniach z szerokimi możliwościami produkcyjnymi Huty Łabędy przy uwzględnieniu potrzeb i spostrzeżeń użytkowników Kopaln. Huta Labędy produkuje prezentowane konstrukcje z nowoczesnych stali 25G2Ti, S480W [1] i S550W [2], dzięki czemu charakteryzują się one wysokimi mechanicznymi parametrami wytrzymałościowymi i podwyższoną odpornością korozyjną.

\section{GENEZA ODRZWI OBUDÓW ROZCINEK ŚCIANOWYCH}

W początkowym okresie eksploatacji pokładów węgla metodą ścianową $\mathrm{z}$ wykorzystaniem kombajnów ścianowych do wykonywania obudów przecinek ścianowych były stosowane odrzwia łukowe podatne typu ŁP [3-5].

Wadą tych rozwiązań była konieczność wypełniania drewnem znacznej przestrzeni stropowej między stropnicą obudowy zmechanizowanej a łukami stropnicowymi obudowy podporowej w celu zapewnienia odpowiedniego rozparcia obudowy zmechanizowanej na etapie zbrojenia ściany i jej rozruchu. W celu zmniejszenia przestrzeni wykładki zaczęto stosować odrzwia ŁP o skróconych łukach ociosowych, co zmniejszało ilość stosowanego drewna do kasztowania, zmniejszając tym samym czas i koszty zbrojenia ściany.

Alternatywą dla tych rozwiązań były odrzwia prostokątne, w których dzięki prostej stropnicy ułatwione było rozparcie sekcji obudowy zmechanizowanej. Jednak niewielka nośność takiej obudowy ograniczała zakres jej stosowania [6, 7]. Konieczne okazało się wzmocnienie płaskiej stropnicy. Jednym z takich rozwiązań jest obudowa o kształcie trapezowym, oznaczona symbolami OPP, której warianty wykonania przedstawiono na rysunkach 1-3 [8]. W zależności od warunków stropowych założono podparcie stropnicy stojakiem pośrednim lub jej przykotwienie.

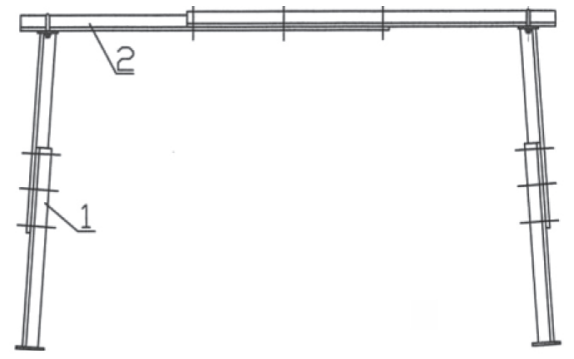

Rys. 1. Odrzwia OPP wariant 1:

1 - stojak (element wsporczy), 2 - stropnica prosta

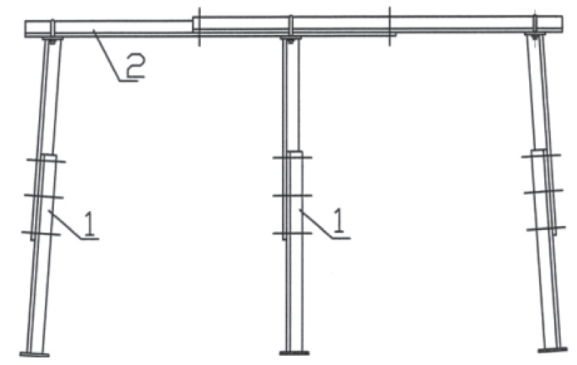

Rys. 2. Odrzwia OPP wariant 2:

1 - stojak (element wsporczy), 2 - stropnica prosta

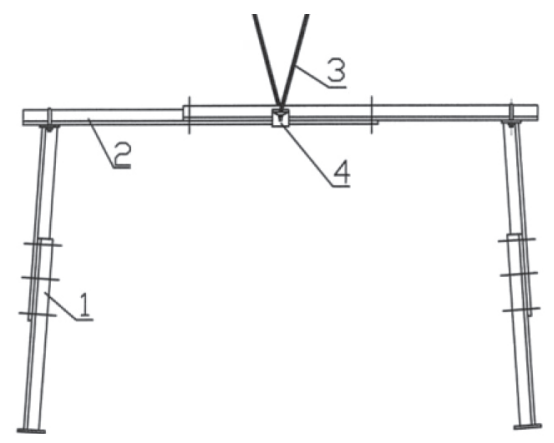

Rys. 3. Odrzwia OPP wariant 3:

1 - stojak (element wsporczy), 2 - stropnica prosta,

$$
3 \text { - kotwa, 4-podkładka }
$$

W związku z dążeniem do optymalizacji geometrii odrzwi przeznaczonych do zabezpieczania rozcinek ścianowych w 1995 roku powstał projekt katalogu obudów [9], zawierający propozycję typoszeregów odrzwi na potrzeby zabezpieczania rozcinek ścianowych. Typoszeregi odrzwi zawarte w katalogu uwzględniały parametry wówczas powszechnie stosowanych sekcji obudów zmechanizowanych. Przyjęto zasadę, że długość manewrowa sekcji (wielkość przekątnej sekcji w pozycji manewrowej powiększona o 5\%) stanowić będzie podstawowe kryterium, określające możliwości wprowadzania danego typu obudowy zmechanizowanej do określonej obudowy rozcinki ścianowej. Przyjęcie tej zasady w doborze odrzwi obudowy rozcinki ścianowej zapewniało możliwość manewrowania wprowadzaną sekcją obudowy zmechanizowanej w pozycji transportowej. Głównymi konstrukcjami zawartymi w ww. katalogu, które zy- 
skały aprobatę kopalń i były powszechnie stosowane w praktyce to typoszereg trzyelementowych odrzwi (kojarzonych) ŁPK, przedstawionych na rysunkach 4 i 5 [9] oraz czteroelementowych odrzwi (kombinowanych) ŁPKO. Odrzwia ŁPK konfigurowane były z różnych wielkości łuków stropnicowych i ociosowych odrzwi ŁP trzyelementowych o wielkościach od 5 do 10 [9]. Rysunki 6 i 7 [10] przedstawiają obudowę przecinki zabezpieczoną obudową $Ł P K$ oraz zbrojenie ściany. Natomiast typoszereg $Ł P K O$, konfigurowany był z dwóch par różnej wielkości łuków ociosowych odrzwi ŁP trzyelementowych o wielkościach 4 do 8 .

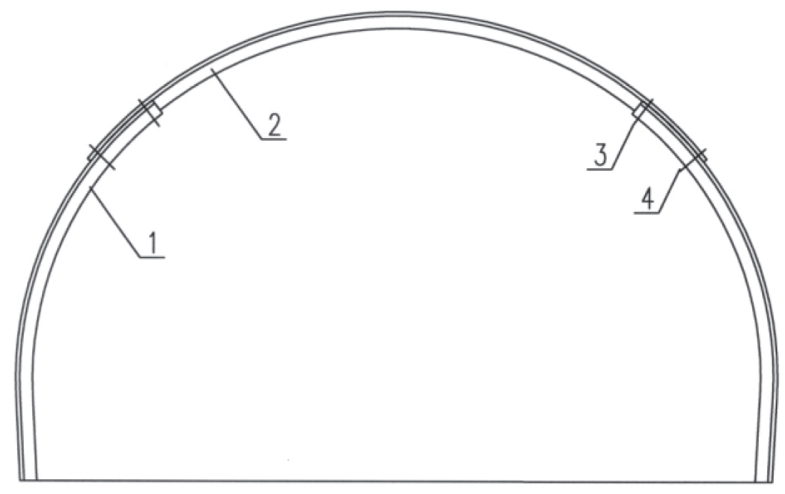

Rys. 4. Odrzwia ŁPK (kojarzone):

1 - tuk ociosowy, 2 - tuk stropnicowy, 3, 4-strzemiona

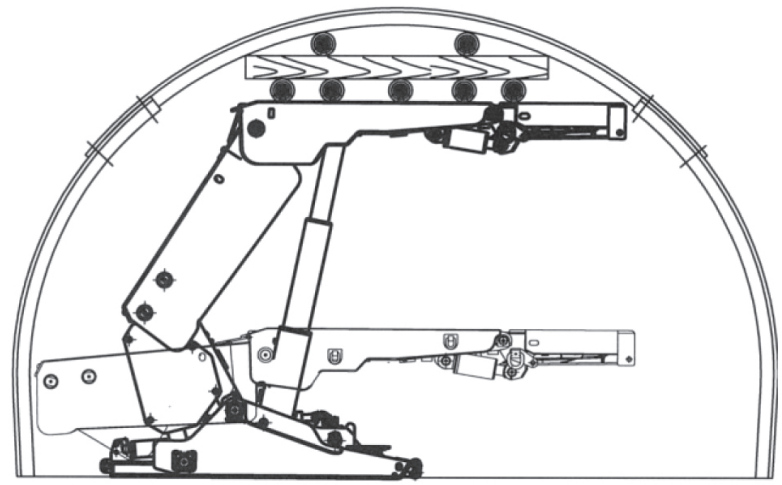

Rys. 5. Odrzwia kojarzone ŁPK z zabudowana sekcja (widok sekcji przed i po rozparciu)

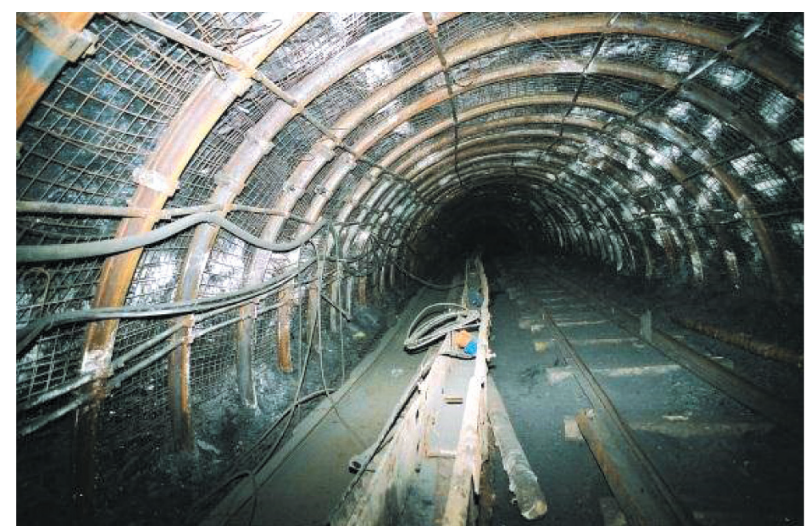

Rys. 6. Rozcinka wykonana w odrzwiach kojarzonych ŁPK ze skróconymi tukami ociosowymi

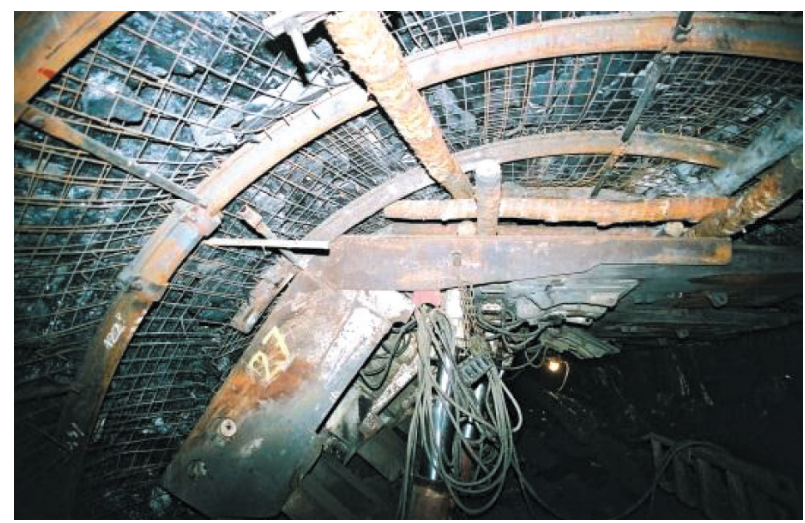

Rys. 7. Zbrojenie ściany, rozcinka wykonana w odrzwiach kojarzonych $Ł P K$

Doświadczenia uzyskane w trakcie drążenia rozcinek ścianowych, a później zbrojenia i rozruchu ściany spowodowały intensywny rozwój konstrukcji w kierunku odrzwi specjalnych, przeznaczonych głównie do zabezpieczania takich wyrobisk.

\section{PRACE I BADANIA NAD ROZWOJEM KONSTRUKCJI ODRZWI}

Prace nad nowymi rozwiązaniami konstrukcyjnymi odrzwi do zabezpieczania rozcinek rozruchowych ścian wynikały głównie z obserwacji pracy i funkcjonalności już stosowanych odrzwi. Obserwacje te obejmowały cały cykl trwania wyrobiska - od drążenia, przez zbrojenie ściany, aż po jej rozruch. Stwierdzone liczne mankamenty zarówno typowych obudów ŁP, kojarzonych $Ł P K$, jak i prostokątnych skłoniły kopalnie, producentów obudów i projektantów do poszukiwania rozwiązań poprawiających funkcjonalność obudowy. W wyniku tych działań powstały liczne rozwiązania konstrukcji odrzwi, stanowiące kompromis pomiędzy obudową łukową ŁP (o wysokich parametrach podpornościowych, ale niekorzystnym obrysie przy rozpieraniu sekcji i rozruchu ściany) i obudową prostokątną (o niskich parametrach podpornościowych, ale bardziej funkcjonalną z uwagi na zbrojenie i rozruch ściany). Prace badawczo-rozwojowe prowadzone były w Zakładzie Technologii Eksploatacji, Tąpań i Obudów Górniczych oraz w Zakładzie Badań Urządzeń Mechanicznych i Skał Głównego Instytutu Górnictwa w Katowicach. Zakres prac obejmował zaprojektowanie konstrukcji odrzwi na podstawie wymagań odbiorców oraz badania laboratoryjne i modelowe, a także uzyskanie stosownego certyfikatu.

Kluczowym etapem prac projektowych są wspomniane wcześniej badania modelowe. $\mathrm{W}$ połączeniu 
z badaniami stanowiskowymi i ich wynikami pozwalają na kalibrowanie modeli numerycznych w celu określenia parametrów podpornościowych całego typoszeregu odrzwi [11, 12]. Wyniki analiz numerycznych są szczególnie istotne w przypadku projektowania i optymalizacji odrzwi o geometrii odbiegającej od typowych odrzwi ŁP, jak to ma miejsce przy odrzwiach łukowo-prostych, spłaszczonych. Analizy takie przeprowadza się metodą elementów skończonych [13, 14], np. za pomocą programu COSMOS/M [15, 16]. $\mathrm{W}$ pierwszym etapie buduje się model geometryczny odrzwi, uwzględniający ich gabaryty i parametry przekrojowe. W następnej kolejności nadaje się odpowiednie parametry materiałowe. Kluczowym zagadnieniem, zwłaszcza przy modelowaniu odrzwi łukowo-prostych, jest zdefiniowanie schematu podparcia i obciążenia odrzwi. Jak istotne są to czynniki, można przekonać się, analizując wyniki symulacji pracy odrzwi łukowo-prostych ŁPrP. Dla zobrazowania tego zagadnienia przeprowadzono analizę wytrzymałościową sześcioelementowych odrzwi ŁPrP w rozmiarze 28 o szerokości nominalnej $6200 \mathrm{~mm}$ i wysokości $2600 \mathrm{~mm}$, wykonanych z kształtownika V29 [17] walcowanego ze stali 25G2 lub 34GJ (wg PN-H-93441-1 [18]). W celu przeprowadzenia tych analiz zbudowano model odrzwi składający się z 126 elementów belkowych (BEAM) modelujących łuki, 10 elementów belkowych modelujących strzemiona oraz z 6 elementów sprężystych (SPRING) modelujących odpór ociosów o określonej sztywności. Kompletny model przedstawiono na rysunku 8 . W wyniku przeprowadzonych symulacji uzyskano zdeformowane postacie odrzwi, wartości reakcji podporowych, rozkłady sił wewnętrznych oraz barwne mapy naprężeń zredukowanych. Przykładowy rozkład naprężeń zredukowanych przedstawiono na rysunku 9.

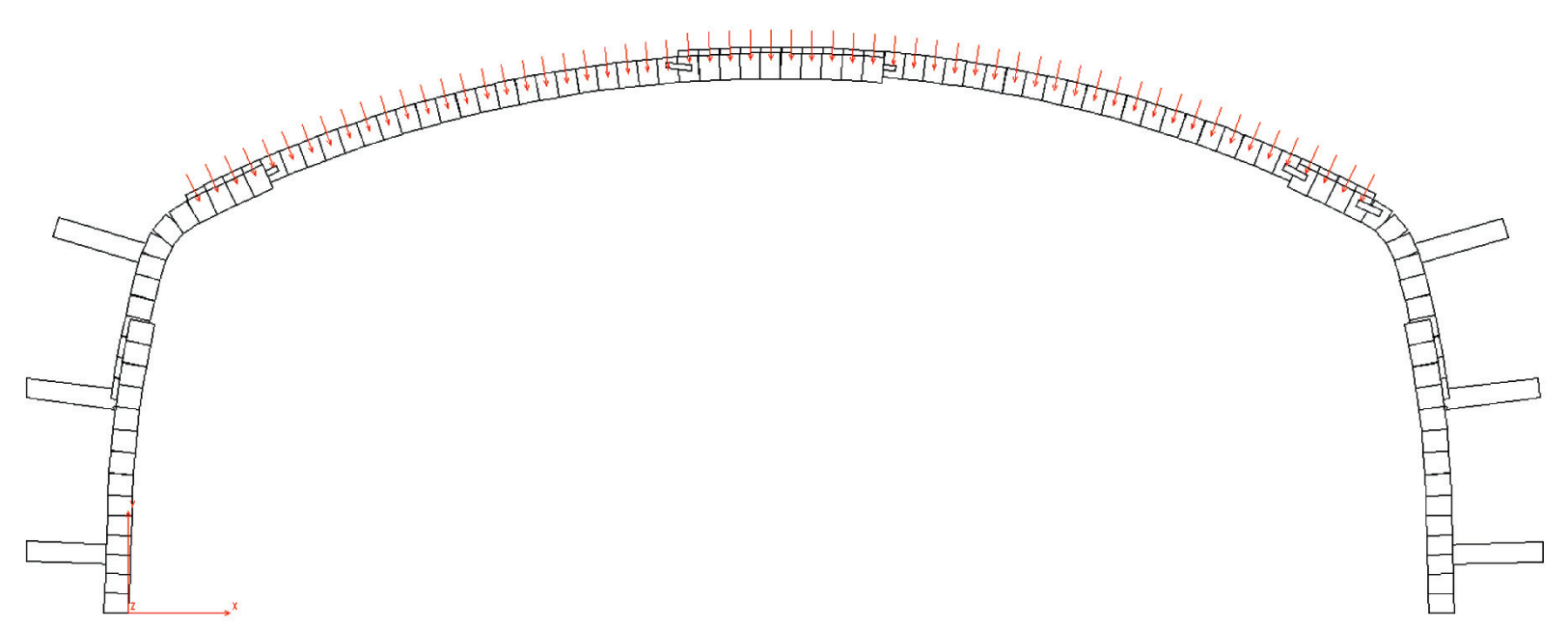

Rys. 8. Model odrzwi ŁPrP/6/B/28 (6200 mm $\times 2600 \mathrm{~mm})$

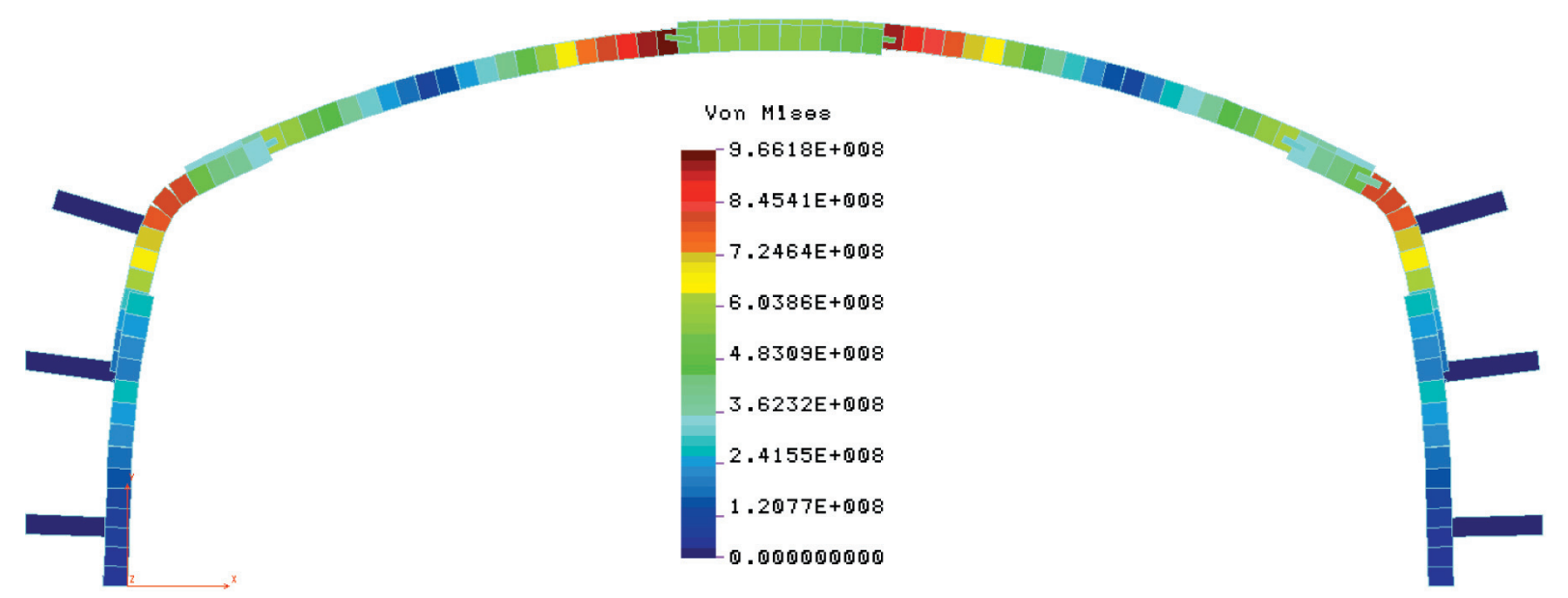

Rys. 9. Rozkład naprężeń zredukowanych $w$ odrzwiach ŁPrP (naprężenia $w$ Pa, skala deformacji 1x, sztywność odporu $k=1 \mathrm{MN} / \mathrm{m}$, długość obciążonego odcinka stropnicy 2,18 m) 
W trakcie badań analizowano wpływ sposobu obciążenia odrzwi (długości obciążonego odcinka stropnicy) na ich nośność oraz wpływ sztywności odporu ociosów na nośność odrzwi. Uwzględniono przy tym wytrzymałość kształtownika V29 wykonanego ze stali wg PN-H-93441-1 [18]. Z analiz wynika, że wraz z wydłużeniem odcinka stropnicy poddanego działaniu obciążenia wyraźnie wzrasta nośność odrzwi. Widać to na wykresie przedstawionym na rysunku 10 . W przypadku analizowanego modelu i sztywności każdego z elementów modelujących odpór ociosu (tzw. wahaczy) na poziomie $k=15 \mathrm{MN} / \mathrm{m}$ odrzwia poddane obciążeniu prawie punktowemu (obciążony odcinek stropnicy $L=200 \mathrm{~mm}$ ) charakteryzują się nośnością $N=183 \mathrm{kN}$, natomiast gdy obciążenie działa na stropnicę na odcinku 5,94 m, nośność osiąga wartość $N=417 \mathrm{kN}$.

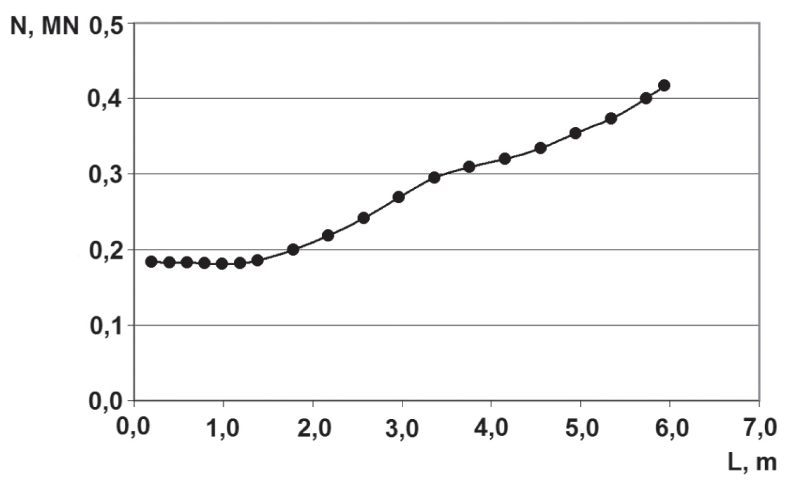

Rys. 10. Nośność odrzwi $N w$ zależności od dtugości obciążonego odcinka stropnicy L dla sztywności elementów modelujących odpór ociosów $k=15 \mathrm{MN} / \mathrm{m}$
Bardzo interesujące wnioski można także wyciągnać z analizy wpływu sztywności odporu na nośność odrzwi. Przy założeniu, że obciążenie działa na całej długości stropnicy w zależności od sztywności odporu nośność odrzwi może zmieniać się w zakresie od $72 \mathrm{kN}$ przy braku odporu ociosów do 417 kN przy szczelnej, sztywnej wykładce. Zmiany te przedstawia wykres na rysunku 11. Wynika z tego konieczność zapewnienia sztywnego odporu ze strony ociosów, zwłaszcza w narożu, na granicy stropu i ociosów.

Dodatkowo zwrócono uwagę na siły wewnętrzne i naprężenia zredukowane w łukach wywołane maksymalnym obciążeniem przenoszonym przez odrzwia. W tabeli 1 przedstawiono odczyty tych wielkości w charakterystycznych miejscach.

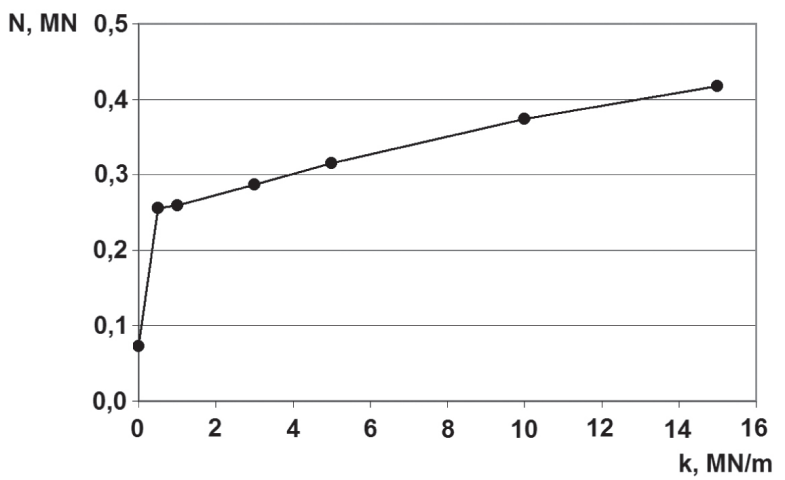

Rys. 11. Nośność odrzwi $N w$ zależności od sztywności

$k$ elementów modelujacych odpór ociosów przy obciążeniu działającym na całej dtugości stropnicy

Tabela 1

Siły wewnętrzne i naprężenia zredukowane w charakterystycznych miejscach odrzwi w chwili osiągnięcia ich nośności dla przypadku obciążenia działającego na całej długości stropnicy i wybranych sztywności odporu ociosów (przekroje, w których następuje utrata nośności kształtownika pogrubiono)

\begin{tabular}{|c|c|c|c|c|c|c|}
\hline \multirow[t]{2}{*}{ Miejsce odczytu } & $\begin{array}{c}\text { Sztywność } \\
\text { elementów } \\
\text { modelujących } \\
\text { odpór ociosów }\end{array}$ & \multirow[t]{2}{*}{ Przekrój } & $\begin{array}{c}\text { Siła } \\
\text { osiowa }\end{array}$ & $\begin{array}{l}\text { Siła } \\
\text { tnąca }\end{array}$ & $\begin{array}{l}\text { Moment } \\
\text { zginający }\end{array}$ & $\begin{array}{l}\text { Naprężenia } \\
\text { zredukowane }\end{array}$ \\
\hline & $k[\mathrm{MN} / \mathrm{m}]$ & & $N[\mathrm{kN}]$ & $T[\mathrm{kN}]$ & $M g[\mathrm{kNm}]$ & $\sigma_{\text {red }}[\mathrm{MPa}]$ \\
\hline \multirow{6}{*}{$\mathbf{A}$} & \multirow{2}{*}{0} & A & 19,3 & 29,2 & 10,0 & 143,8 \\
\hline & & B & 8,8 & 6,5 & 57,7 & 625,0 \\
\hline & \multirow{2}{*}{0,5} & A & 139,7 & 56,1 & 50,9 & 581,7 \\
\hline & & B & 115,9 & 15,9 & 54,3 & 625,0 \\
\hline & \multirow{2}{*}{15,0} & $\mathbf{A}$ & 331,9 & 23,9 & 47,6 & 625,0 \\
\hline & & B & 312,9 & 16,3 & 31,4 & 434,6 \\
\hline
\end{tabular}


Jak wynika z przedstawionego zestawienia w przypadku braku odporu ociosów, uszkodzeniom ulega stropnica tuż przy złączu ciernym (przekrój B). Powstają w tym miejscu momenty zginające o dużych wartościach, a odrzwia pracują jak sztywne, ponieważ przy niewielkich wartościach sił osiowych nie mogą wystapić zsuwy w zakładkach [19-21]. Sytuacja ta ma miejsce już przy niewielkich wartościach obciążenia. Natomiast przy sztywnym odporze ociosów utrata nośności odrzwi następuje przez przekroczenie wytrzymałości elementu narożnego w miejscu o dużej krzywiźnie (tzw. hokejki). Jednocześnie w stropnicy naprężenia mają wyraźnie niższe wartości, a duże siły osiowe i niewielki moment zginający tuż przy złączu ciernym umożliwiają zsuw $\mathrm{w}$ zakładkach i pracę odrzwi jako podatne. Dodatkowo przedstawiona analiza wskazuje na znaczenie elementu narożnego w nośności całych odrzwi. Element ten musi być wykonany dokładnie i z odpowiednich materiałów, tym bardziej że proces gięcia kształtownika $\mathrm{V}$ na tak mały promień stawia szereg wymagań co do parametrów materiałowych.

Prototypy odrzwi w skali naturalnej są badane w stanowisku badawczym w Zakładzie Badań Urządzeń Mechanicznych i Skał Głównego Instytutu Górnictwa, przedstawionym na rysunku 12 . W trakcie badań odrzwia w stanie usztywnionym i podatnym zostają poddane obciążeniom statycznym. Celem tych badań jest wyznaczenie rzeczywistych parametrów nośnościowo-deformacyjnych nowej konstrukcji odrzwi i potwierdzenie ich poprawnej pracy. Badania odrzwi prowadzane były wg normy PN-G-15000-05 [22], zaś obecnie stosowana jest norma PN-G-15022 [23]. Określają one sposób podparcia i obciążania, a także pozostałe parametry badania. Na rysunku 13 przedstawiono schemat obciążania badanych odrzwi na stanowisku badawczym. Oprócz badań całych konstrukcji przeprowadza się też badania złączy ciernych, które odpowiadają za właściwą pracę odrzwi [19-21].

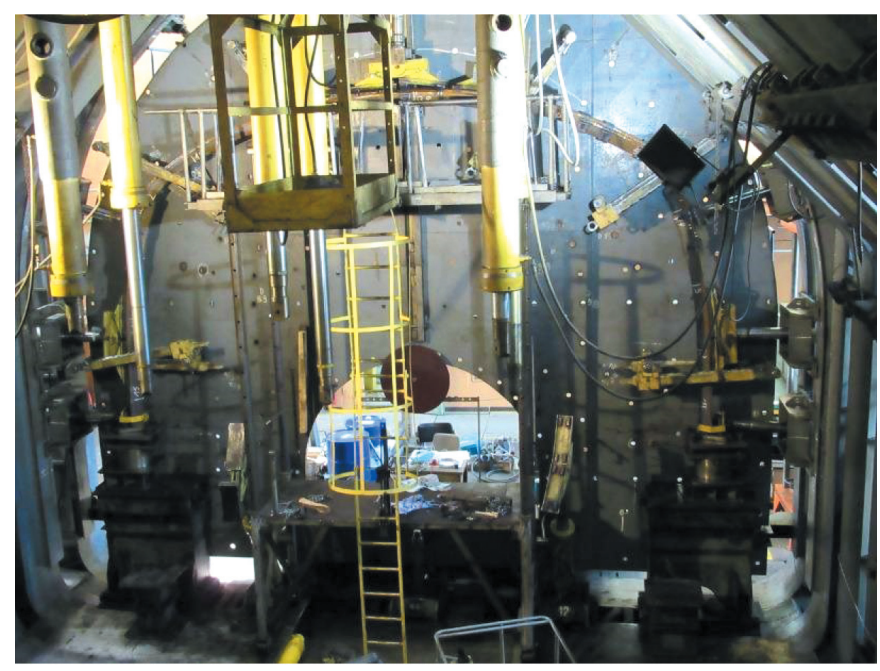

Rys. 12. Stanowisko badawcze z zainstalowanymi odrzwiami w trakcie badań

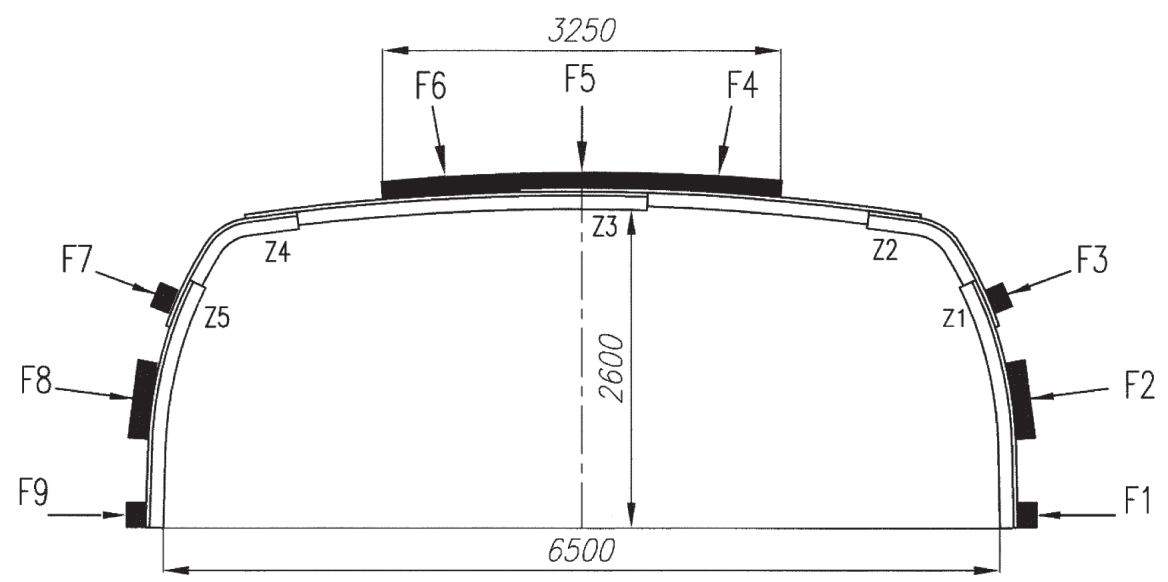

Rys. 13. Schemat obciażenia odrzwi łukowo-prostych $w$ stanowisku badawczym ( $F_{4}, F_{5}, F_{6}-$ sity czynne, $F_{1}, F_{2}, F_{3}, F_{7}, F_{8}, F_{9}-$ sity bierne) 
Wyniki uzyskane ze stanowiskowych badań konstrukcji odrzwi pozwalają na porównanie z wynikami obliczeń numerycznych i badań zarówno innych konstrukcji przeznaczonych do rozcinek, jak i typowych odrzwi obudowy ŁP. Analiza wyników pozwala również na doprecyzowanie cyfrowych modeli odrzwi (kalibracja modeli) i jest podstawą do wprowadzenia ewentualnych zmian w ich konstrukcji. Sprawozdanie z badań stanowiskowych odrzwi i dokumentacja techniczno-ruchowa są podstawą do udzielenia producentowi certyfikatu uprawniającego do oznaczania odrzwi znakiem bezpieczeństwa „B” (B).

\section{ODRZWIA DO ROZCINEK ŚCIANOWYCH PRODUKCJI HUTY ŁABĘDY}

Jednym z pierwszych rozwiązań konstrukcyjnych przeznaczonych do zabezpieczania rozcinek ścianowych jest typoszereg odrzwi ŁPKO. Został on opracowany na podstawie sugestii zawartych $\mathrm{w}$ projekcie katalogu z 1995 roku [9] oraz doświadczeń górniczych w czasie wykonywania robót przygotowawczych.
Typoszereg usystematyzowano i rozszerzono o nowe warianty wykonywane ze wszystkich kształtowników typu $\mathrm{V}$ powszechnie stosowanych $\mathrm{w}$ kopalniach. Odrzwia obudowy typu ŁPKO i ŁPKOw przeznaczone są głównie do zabezpieczania rozruchowych rozcinek ścianowych, w których zabudowywane będą sekcje obudowy zmechanizowanej. W konstrukcji odrzwi ŁPKO wykorzystywane są znormalizowane i produkowane seryjnie łuki ociosowe trzyelementowych odrzwi ŁP i ŁPP (w rozmiarach 7-10). W celu precyzyjnego dopasowania geometrii odrzwi do planowanego wyrobiska dopuszcza się modyfikację odrzwi przez skrócenie łuku ociosowego od strony odcinka prostego oraz zmianę wielkości zakładek. W ostatnim czasie typoszereg odrzwi ŁPKO został rozszerzony o wariant $Ł P K O w$ oparty na łukach ociosowych trzyelementowych odrzwi ŁPw i ŁPPw, które charakteryzują się jednym promieniem gięcia łuków ociosowych i stropnicowych [24-27]. Rozszerzony typoszereg obejmuje odrzwia o szerokości 5400-8485 mm i wysokości 3145-5320 mm. Na rysunkach 14 i 15 pokazano konstrukcję odrzwi ŁPKOw i ŁPKO, a na rysunku 16 [28] - rozcinkę zabezpieczoną obudową ŁPKO.

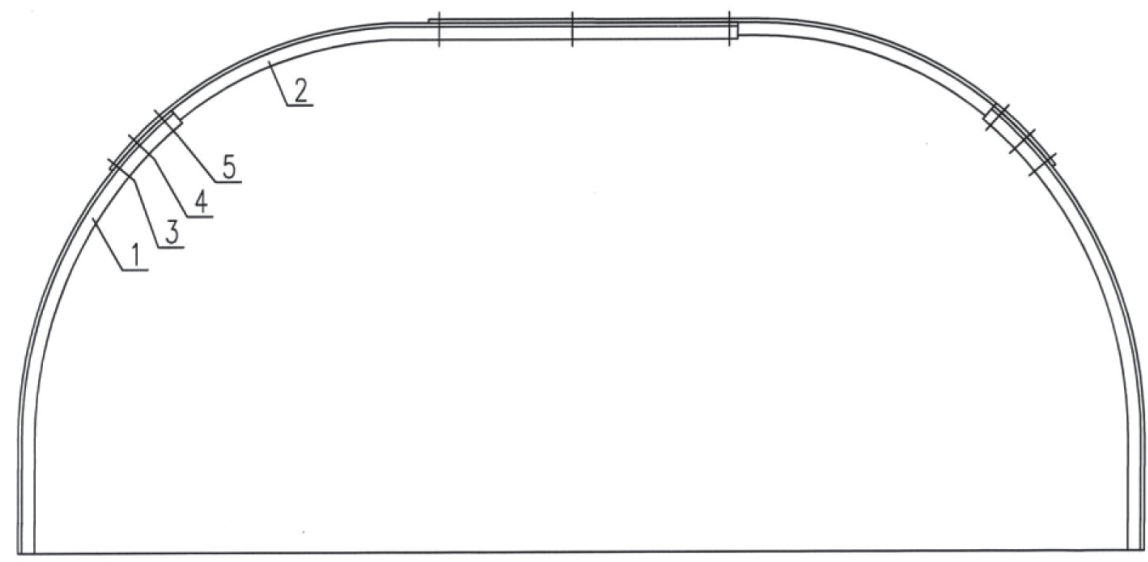

Rys. 14. Odrzwia ŁPKOw: 1 - tuk ociosowy odrzwi ŁP, 2 - tuk ociosowy odrzwi ŁPP zabudowany jako stropnicowy, 3-5 - strzemiona

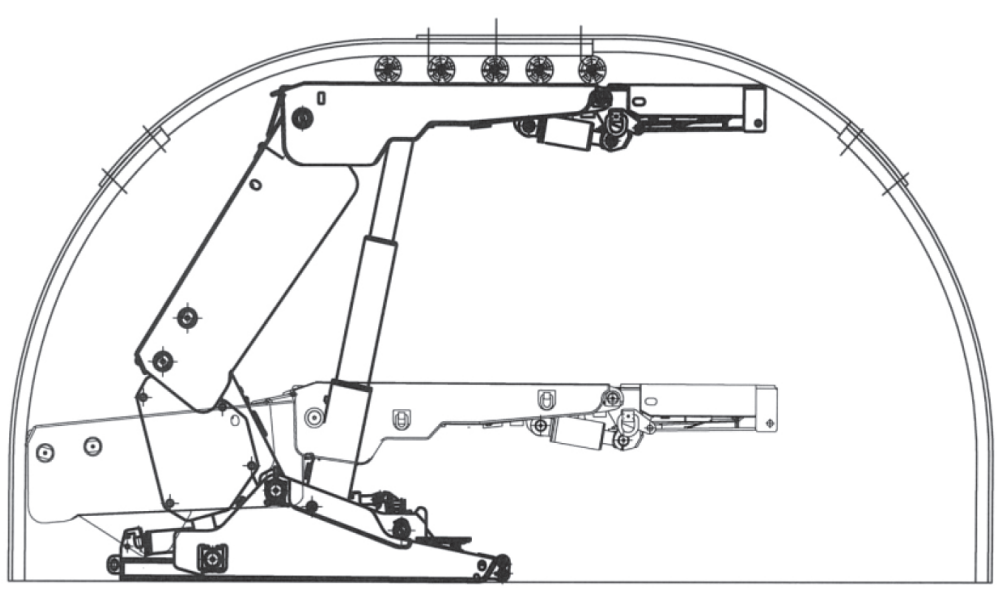

Rys. 15. Odrzwia ŁPKO z zabudowana sekcja (widok sekcji przed rozparciem i po nim) 


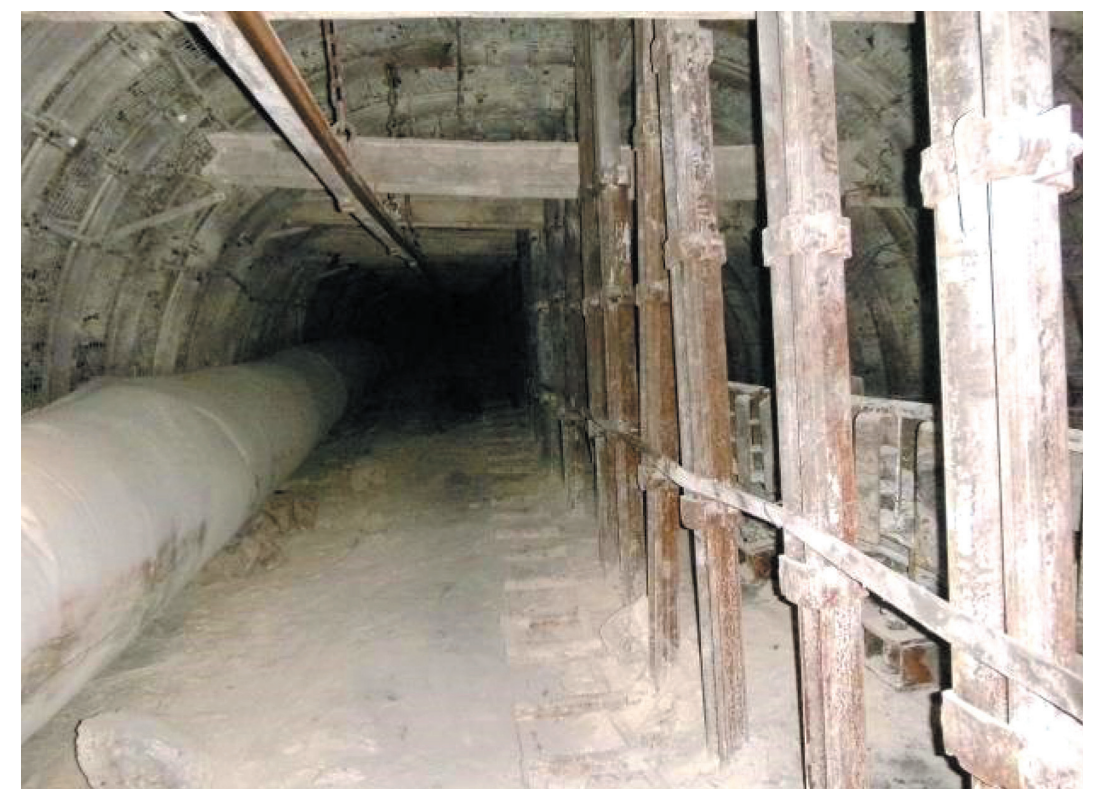

Rys. 16. Rozcinka zabezpieczona obudowa ŁPKO

Pewną modyfikacją typoszeregu ŁPKO są odrzwia ŁPro/B. Na jednym ociosie zabudowana jest „połówka" odrzwi ŁPKO, natomiast na drugim - prosty odcinek kształtownika V podparty stojakiem. Uzyskane w ten sposób odrzwia mają obrys lukowo-prostokątny [29]. W 2003 roku zostały opracowane dwa typoszeregi tych odrzwi - ŁPro/A i ŁPro/B. Odrzwia łukowoprostokątne typoszeregu $\mathrm{LPro/B}$ przeznaczone są głównie do zabezpieczania rozcinek ścianowych i kanałów likwidacyjnych ścian, gdzie sprawdzają się w trakcie zbrojenia i rozruchu ściany, a także przy kończeniu wybiegu ścian. Odrzwia te w konfiguracji z odrzwiami KaPa [30] mogą być stosowane z po-
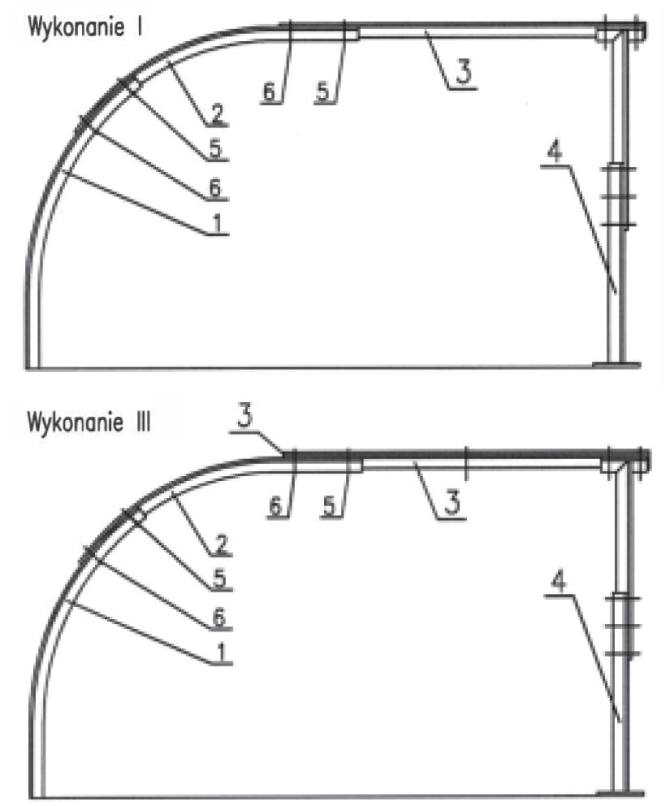

wodzeniem do zabezpieczania skrzyżowań wyrobisk korytarzowych [31]. Typoszereg odrzwi ŁPro/B występuje w czterech wariantach wykonania, przedstawionych na rysunku 17 . Wykonania I i III stanowią wersję z dwuelementową stropnicą, a wykonanie II i IV to wariant $\mathrm{z}$ jednoelementową stropnicą nazywaną w żargonie górniczym „fajką”. Typoszereg obejmuje odrzwia o szerokości 3120-7900 mm i wysokości $3200-5420 \mathrm{~mm}$. Z racji obrysu odrzwi doskonale wpisują się w nie sekcje obudowy zmechanizowanej, co pokazano na rysunku 18. Natomiast przykłady zastosowania tej obudowy w wyrobisku przedstawiono na rysunkach 19 i 20.
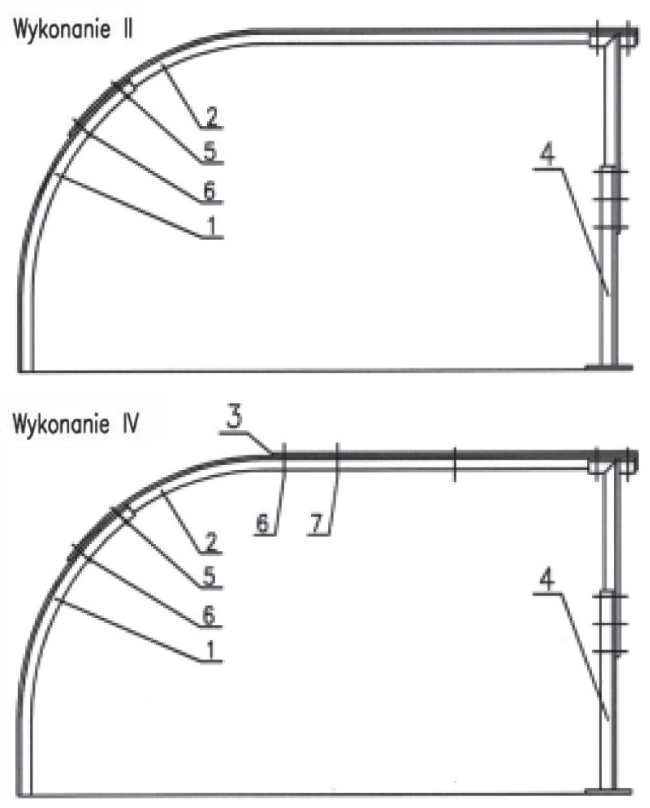

Rys. 17. Odrzwia ŁPro/B: 1 - łuk ociosowy, 2 - tuk ociosowy górny, 3 - stropnica prosta, 4-stojak (element wsporczy), 


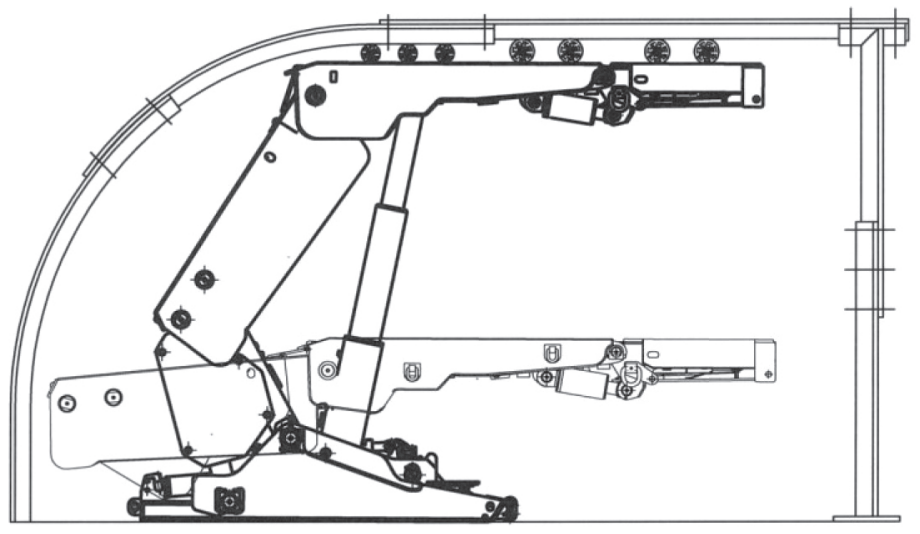

Rys. 18. Odrzwia ŁPro/B, wykonanie I z zabudowana sekcja (widok sekcji przed rozparciem i po nim)

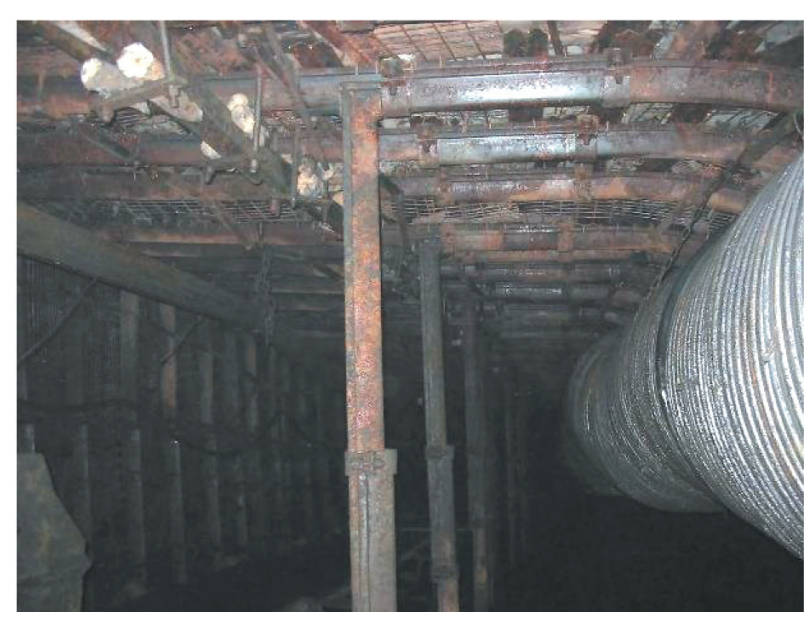

Rys. 19. Rozcinka rozruchowa zabezpieczona obudowa $€$ Pro/B

Odmianą wykorzystującą ideę odrzwi ŁPro/B są odrzwia łukowo prostokątne typoszeregu ŁPro/A, przedstawione na rysunkach 21 i 22. Podobnie jak odrzwia typoszeregu ŁPro/B przeznaczone są głównie do zabezpieczania rozcinek ścianowych, kanałów likwidacyjnych ścian oraz skrzyżowań wyrobisk chodnikowych. Typo-

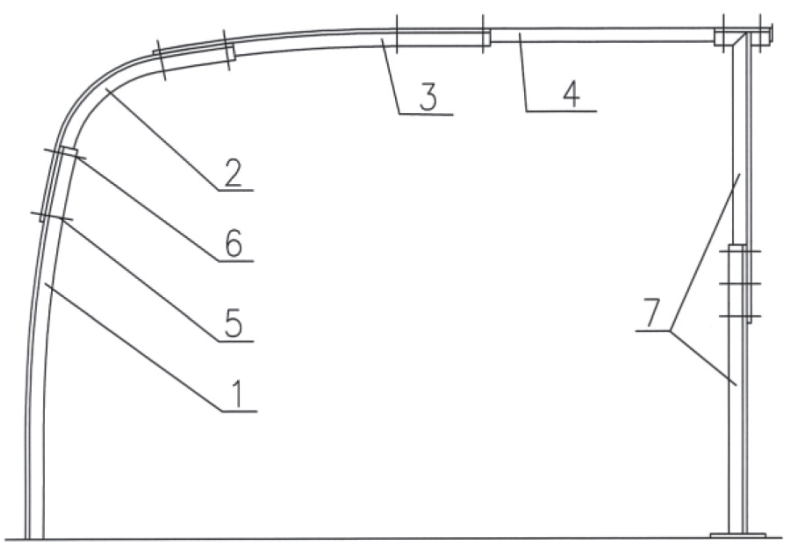

Rys. 21. Odrzwia ŁPro/A: 1 - tuk ociosowy, 2 - tuk ociosowy górny, 3 - tuk stropnicowy, 4 - stropnica prosta, 7 -stojak (element wsporczy), 5, 6-strzemiona

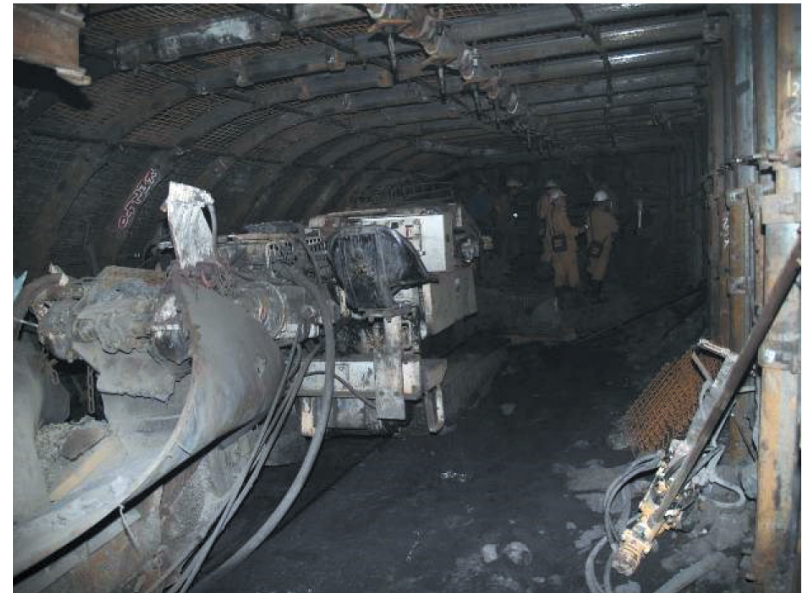

Rys. 20. Kanat likwidacyjny ściany zabezpieczony obudowa ŁPro/B

szereg powstał w 2003 roku na potrzeby LW „Bogdanka”. Konstrukcja oparta jest na elementach łukowych odrzwi ŁPrP K, omówionych w dalszej części artykułu, a zakres gabarytów obejmuje szerokość 5900-6900 mm i wysokość 3300-4400 mm. Przykłady zastosowania odrzwi ŁPro/A przedstawiono na rysunkach 23 i 24.

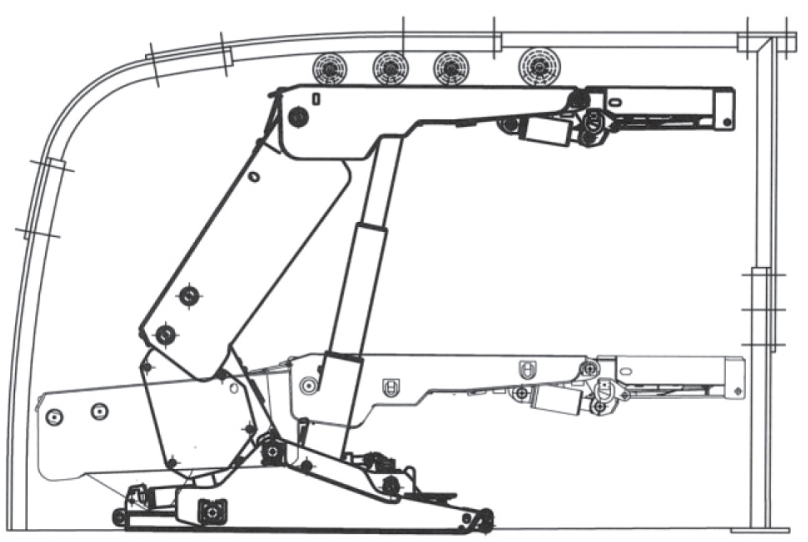

Rys. 22. Odrzwia ŁPro/A z zabudowana sekcja (widok sekcji przed rozparciem i po nim) 


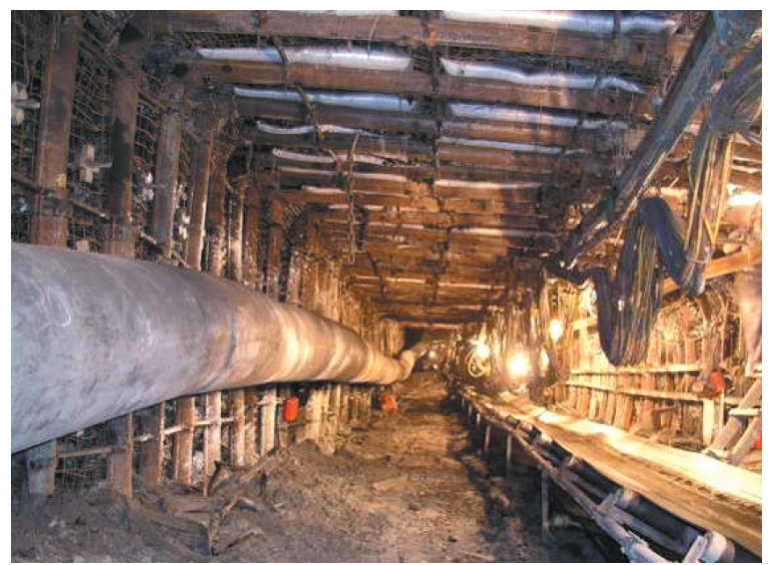

Rys. 23. Rozcinka ścianowa zabezpieczona obudowa ŁPro/A

Obserwacje pracy obudów z prostoliniową stropnicą i zidentyfikowane mankamenty z tym związane spowodowały opracowanie nowego typoszeregu o łukowej, spłaszczonej stropnicy - o niewielkiej krzywiźnie. Jedną z pierwszych konstrukcji tego typu są odrzwia ŁPS - pierwsza wersja powstała w 1995 roku. Są to odrzwia łukowo-proste z przeznaczeniem do wykonywania obudowy rozcinek ścianowych. Konstrukcja odrzwi obejmuje dwa warianty: pierwszy -

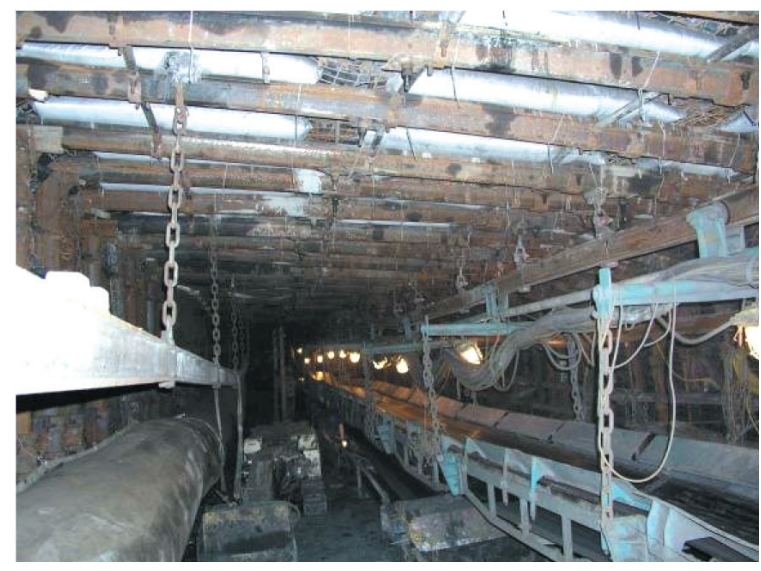

Rys. 24. Rozcinka ścianowa zabezpieczona obudowa ŁPro/A

$\mathrm{z}$ jednoelementową stropnicą, przedstawiony na rysunku 25, oraz wariant drugi z dwuelementową stropnicą, pokazaną na rysunku 26 . Z uwagi na sposób połączenia łuku stropnicowego $\mathrm{z}$ łukiem ociosowym (krótka zakładka) były to odrzwia sztywne. Brak podatności odrzwi znacznie ograniczał ich zastosowania, w rezultacie czego obudowa ta została zastąpiona przez odrzwia ŁPrP, stosowane do obecnych czasów.

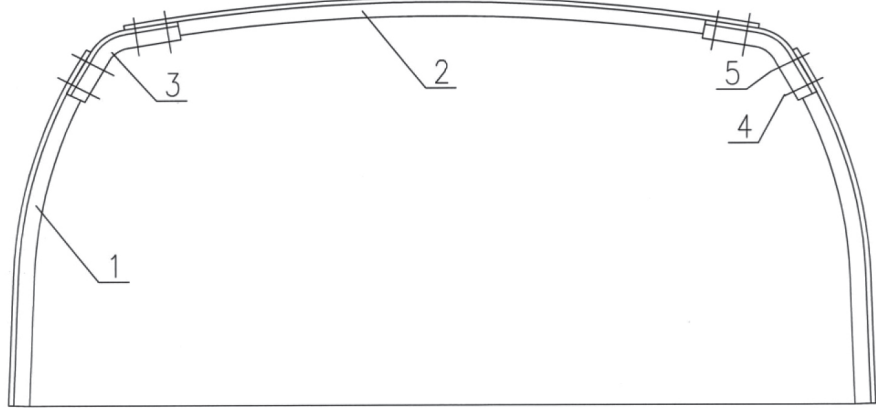

Rys. 25. Odrzwia ŁPS z jednoelementowq stropnica: 1 - tuk ociosowy, 2- tuk stropnicowy, 3-tacznik, 4, 5 - strzemiona

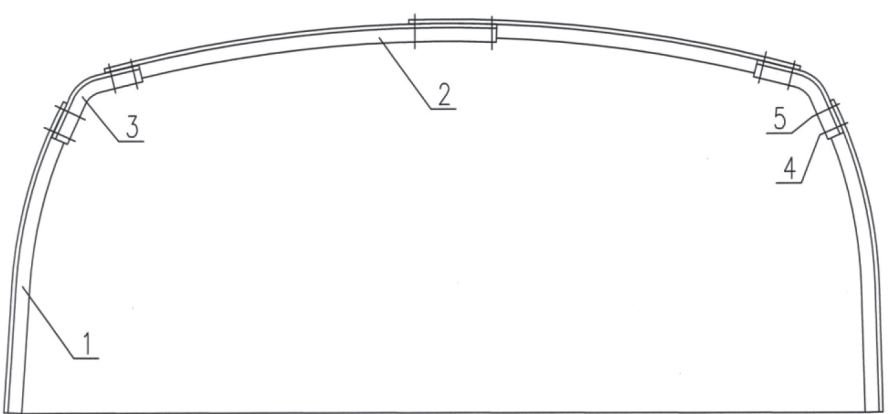

Rys. 26. Odrzwia ŁPS z dwuelementowa stropnica: 1 - tuk ociosowy, 2 - tuk stropnicowy, 3 - tacznik, 4, 5 - strzemiona

Wspomniane wcześniej odrzwia łukowo-proste ŁPrP są kolejnym typoszeregiem odrzwi wpisującym się $\mathrm{w}$ trend konstrukcji dedykowanych do wykonywania obudów przecinek ścianowych. Został on opracowany w 1997 roku w Głównym Instytucie Górnictwa. Odrzwia łukowo prostokątne podatne $Ł P r P$ z kształ- towników typu V przeznaczone są głównie do zabezpieczania rozcinek ścianowych, jak również innych wyrobisk korytarzowych funkcyjnych o zwiększonych wymiarach poprzecznych. Spłaszczona geometria odrzwi w stosunku do normowych odrzwi ŁP ogranicza urabianie skały płonnej $\mathrm{w}$ strefie stropowej 
w przypadku niskich pokładów, a zwiększona szerokość ułatwia zbrojenie ścian wydobywczych. Typoszereg obejmuje odrzwia w trzech wariantach wykonania:

- czteroelementowym o szerokości 4700-7650 mm i wysokości 2100-3000 mm (rys. 27 i 28), ze stropnicą o trzech krzywiznach, wyprofilowaną do połączenia z łukiem ociosowym;

- pięcioelementowym o szerokości 3700-4200 mm i wysokości 2100-3000 mm (rys. 29 i 30), z niedzieloną stropnicą i elementami narożnymi do łączenia stropnicy z łukami ociosowymi;

- sześcioelementowym o szerokości 4700-7650 mm i wysokości 2100-3000 mm (rys. 31 i 32), z dzieloną stropnicą i elementami narożnymi do łączenia stropnic z łukami ociosowymi.

Odrzwia zyskały uznanie działów górniczych ds. robót przygotowawczych, czego dowodem mogą być

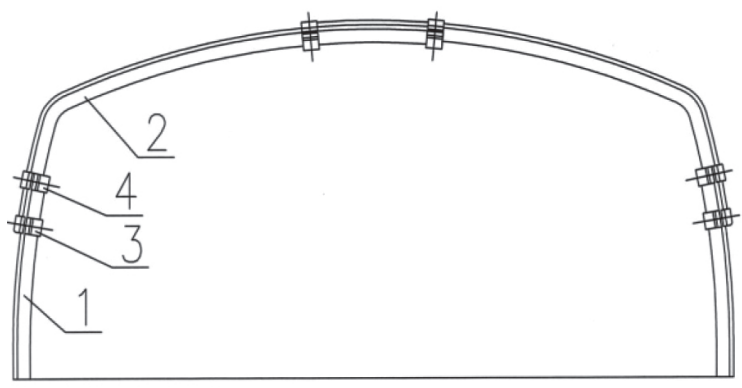

Rys. 27. Odrzwia ŁPrP czteroelementowe:

1- tuk ociosowy, 2- tuk stropnicowy, 3, 4-strzemiona

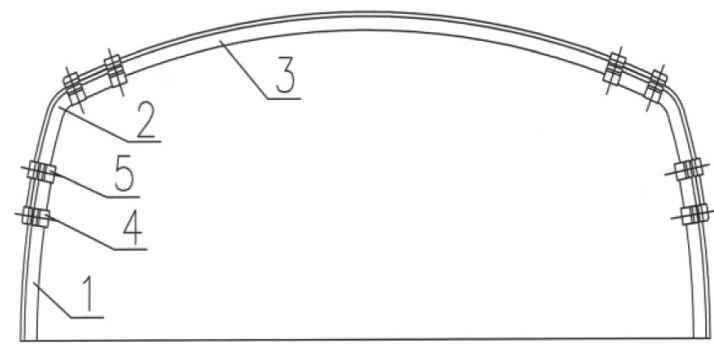

Rys. 29. Odrzwia ŁPrP pięcioelementowe:

1 - tuk ociosowy I, 2 - tuk ociosowy II,

3 - tuk stropnicowy, 4, 5 - strzemiona

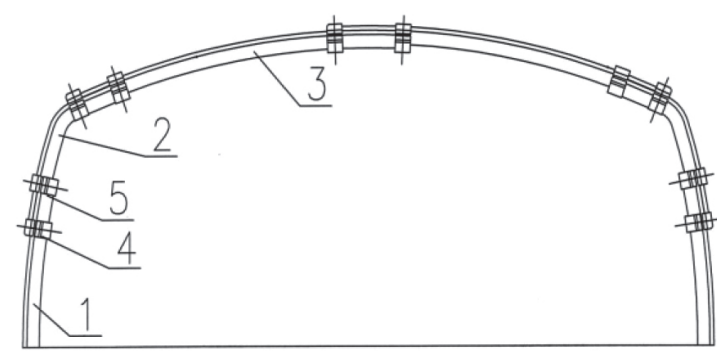

Rys. 31. Odrzwia ŁPrP sześcioelementowe: 1 - łuk ociosowy I, 2 - tuk ociosowy II, 3 - tuk stropnicowy, 4, 5 - strzemiona przykładowe zastosowania, przedstawione na rysunkach 33 i 34 [10].

W roku 2000 typoszereg odrzwi ŁPrP został rozszerzony o warianty $\mathrm{LPrP}$ wykonane z ciężkich kształtowników - V32 i V36 pod kątem zastosowań w LW „Bogdanka”. Odrzwia zostały zaprojektowane w dwóch wykonaniach nieznacznie się różniących obrysem, a ich oznaczenia nawiązywały do ówczesnych nazw producentów Huty Łabędy Ł i Huty Katowice K. Dodatkowo zaprojektowane zostały spąnice, zabudowywane opcjonalnie w razie konieczności. Odrzwia przewidziano do zabezpieczania wyrobisk w zakresie szerokości 4800-6400 mm i wysokości 3300-4400 mm. Na rysunkach 35 i 36 przedstawiono odrzwia $Ł P r P ~ Ł$, a na rysunkach 37 i 38 - odrzwia $Ł P r P ~ K$. Natomiast przykładowe realizacje obudowy przedstawiono na rysunkach 39-44.

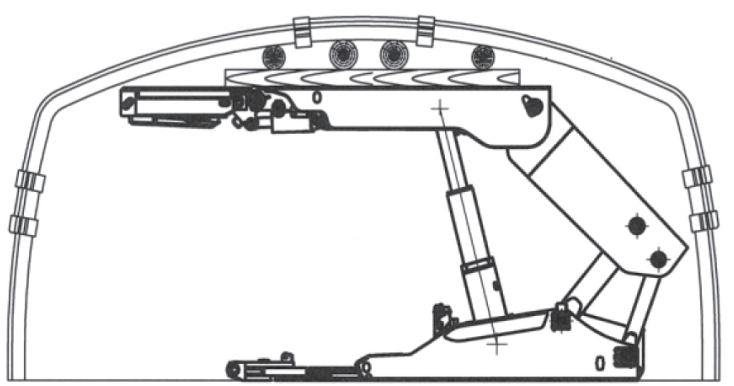

Rys. 28. Odrzwia ŁPrP czteroelementowe: widok $z$ zabudowana sekcja obudowy zmechanizowanej

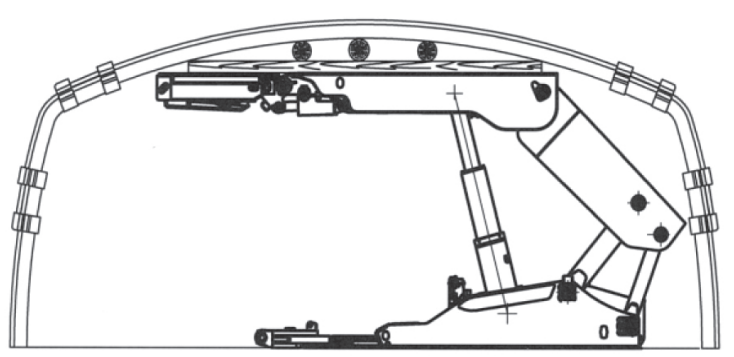

Rys. 30. Odrzwia ŁPrP pięcioelementowe: widok z zabudowana sekcja obudowy zmechanizowanej

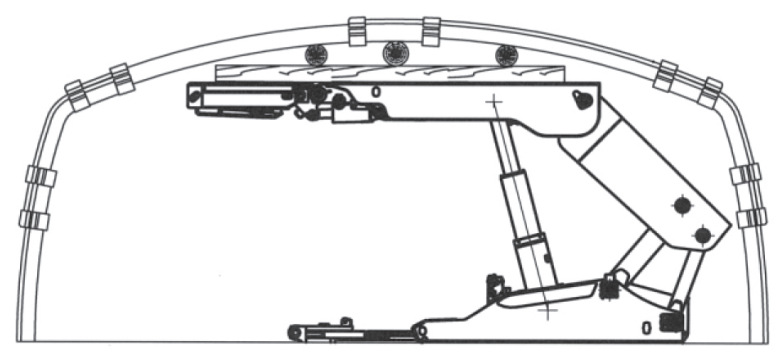

Rys. 32. Odrzwia ŁPrP sześcioelementowe: widok z zabudowana sekcja obudowy zmechanizowanej 


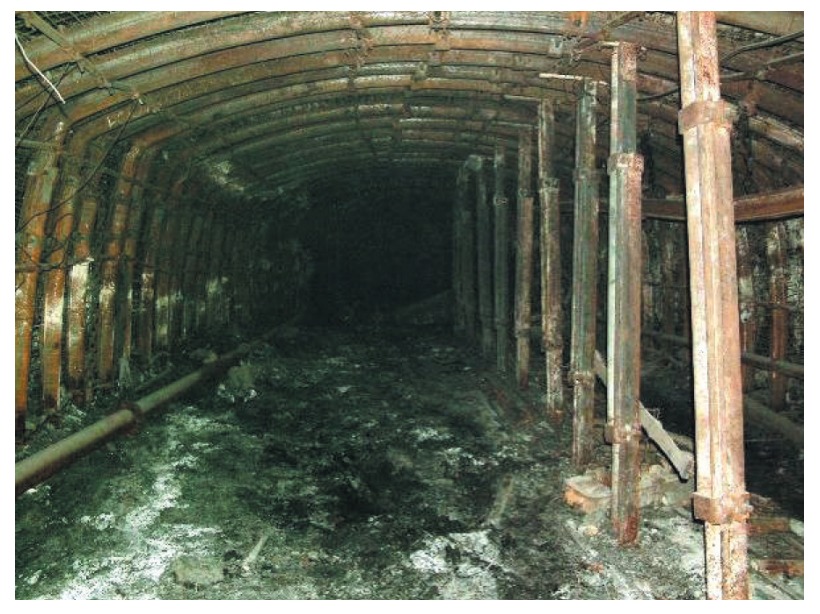

Rys. 33. Rozcinka ścianowa zabezpieczona odrzwiami ŁPrP czteroelementowymi

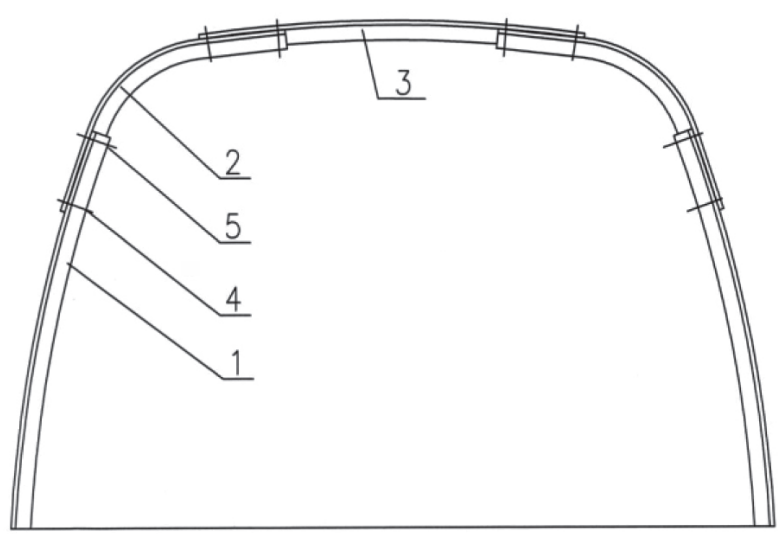

Rys. 35. Odrzwia ŁPrP, wykonanie Ł: 1 - tuk ociosowy I, 2 - tuk ociosowy II, 3 - tuk stropnicowy, 4, 5 - strzemiona

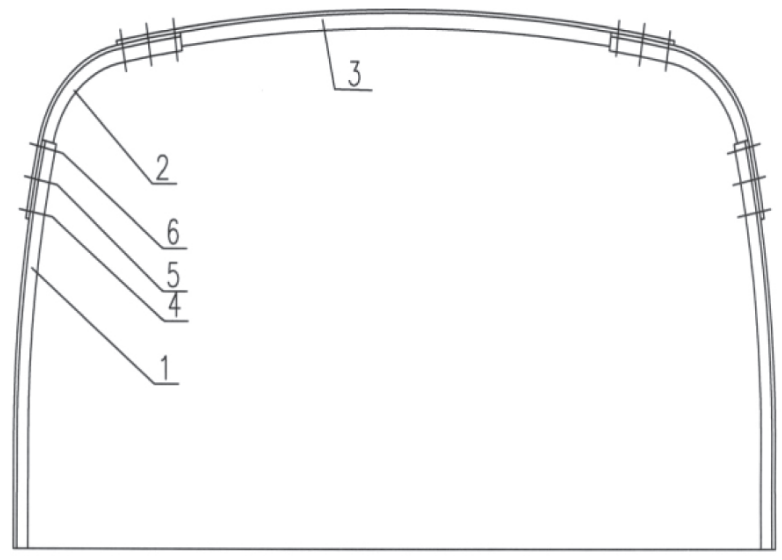

Rys. 37. Odrzwia ŁPrP, wykonanie K: 1 - tuk ociosowy I, 2 - tuk ociosowy II, 3 - tuk stropnicowy,

$$
\text { 4-6 - strzemiona }
$$

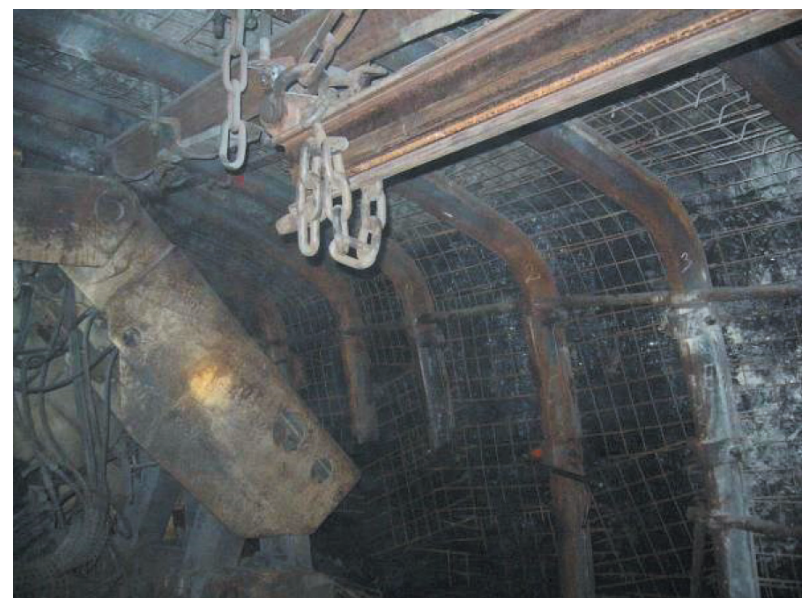

Rys. 34. Zbrojenie ściany, rozcinka zabezpieczona odrzwiami ŁPrP czteroelementowymi

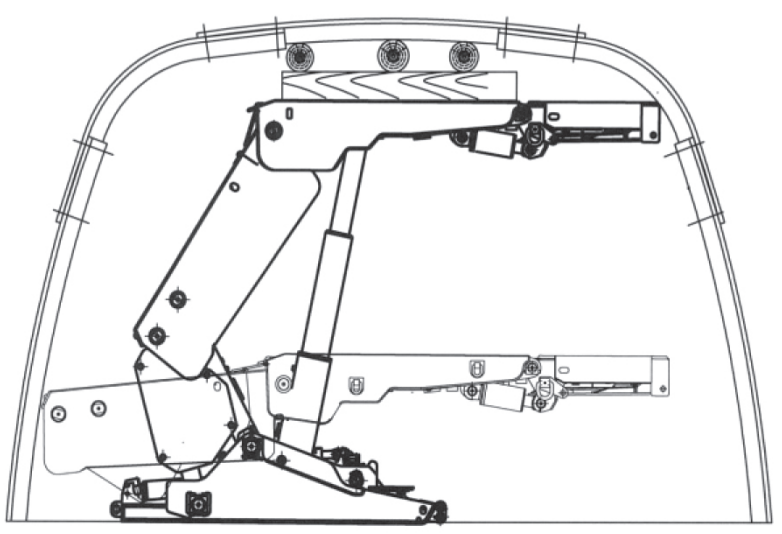

Rys. 36. Odrzwia ŁPrP, wykonanie Ł z zabudowana sekcja (widok sekcji przed rozparciem i po nim)

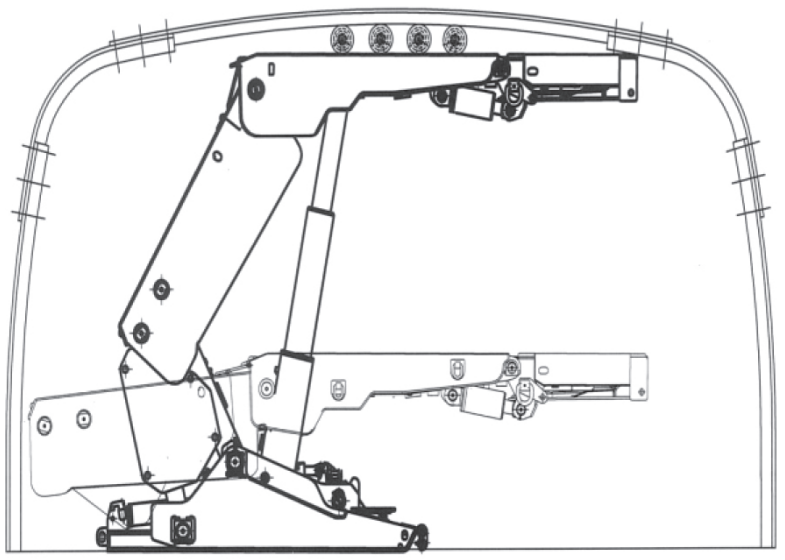

Rys. 38. Odrzwia ŁPrP, wykonanie $K z$ wprowadzona sekcja obudowy zmechanizowanej 


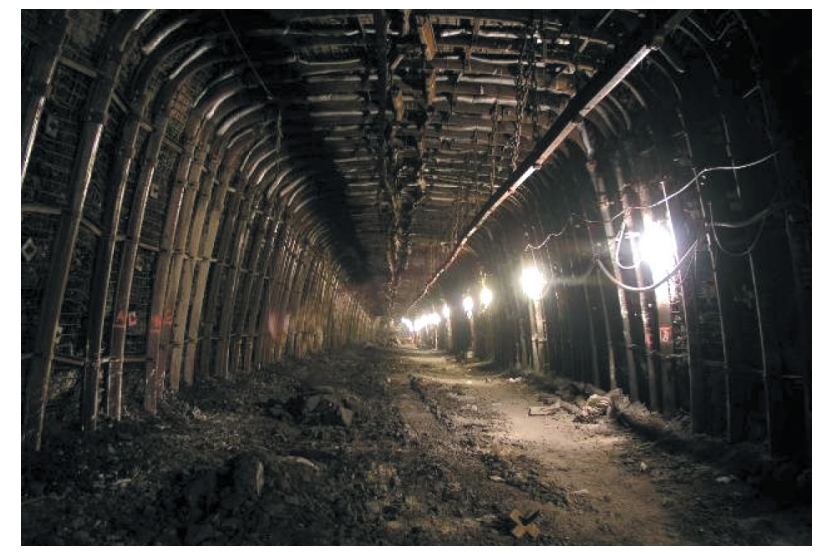

Rys. 39. Rozcinka ścianowa zabezpieczona obudowa ŁPrP, wykonanie $七$

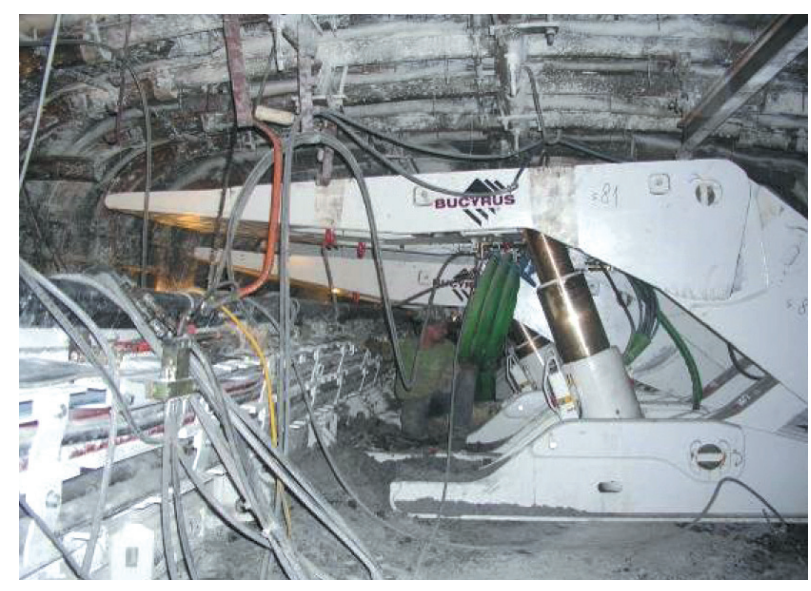

Rys. 41. Zbrojenie ściany w rozcince ścianowej zabezpieczonej obudowa $Ł P r P$, wykonanie $K$

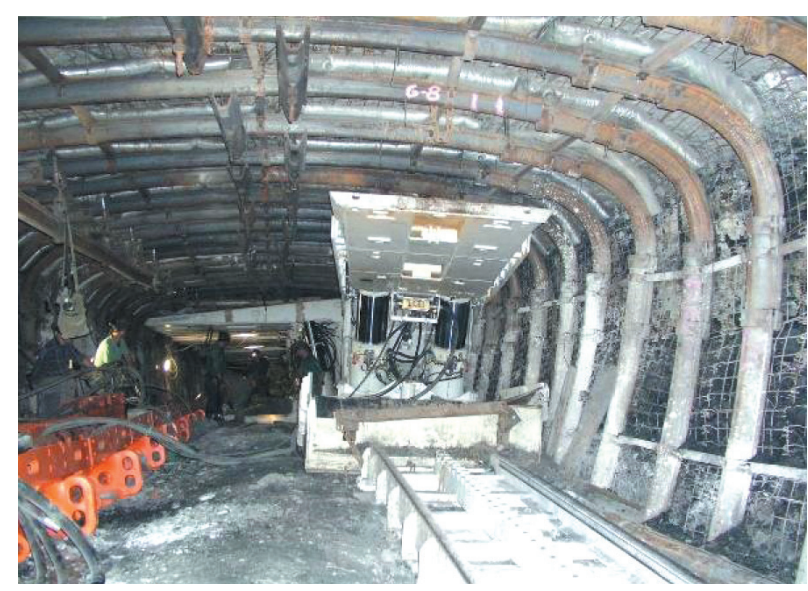

Rys. 44. Dworzec zrealizowany

w obudowie $€$ PrP, wykonanie $€$

Pewną modyfikacją i rozszerzeniem powyższych są odrzwia łukowo-proste wzmocnione $\mathrm{LPrw}$, przedstawione na rysunkach 45 i 46, wykonywane są z kształtowników V29, V32, V34 i V36. Obudowa została zaprojektowana z myślą o zabezpieczaniu rozcinek rozruchowych ścian prowadzonych z podsadzką hydrauliczną, umożliwiającą uzbrojenie w sekcje o znacz-

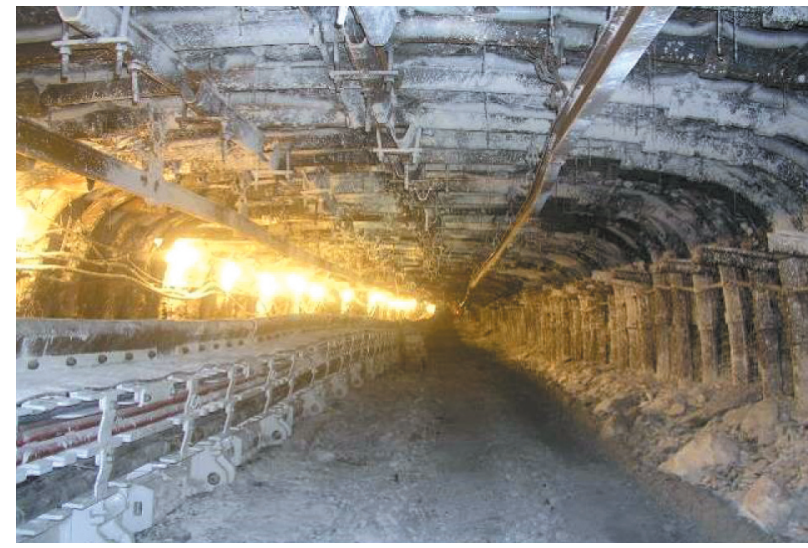

Rys. 40. Rozcinka ścianowa zabezpieczona obudowa $Ł P r P$, wykonanie $K$

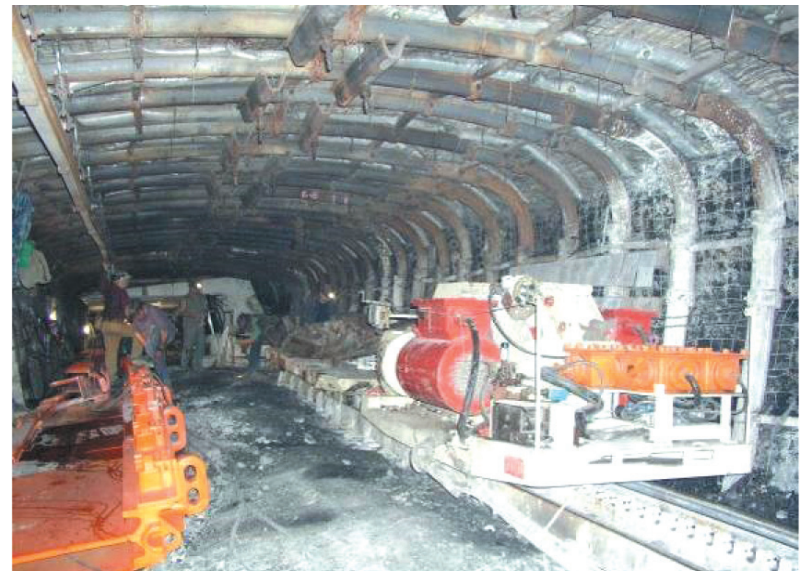

Rys. 42. Zbrojenie ściany w rozcince ścianowej zabezpieczonej obudowa ŁPrP, wykonanie $K$

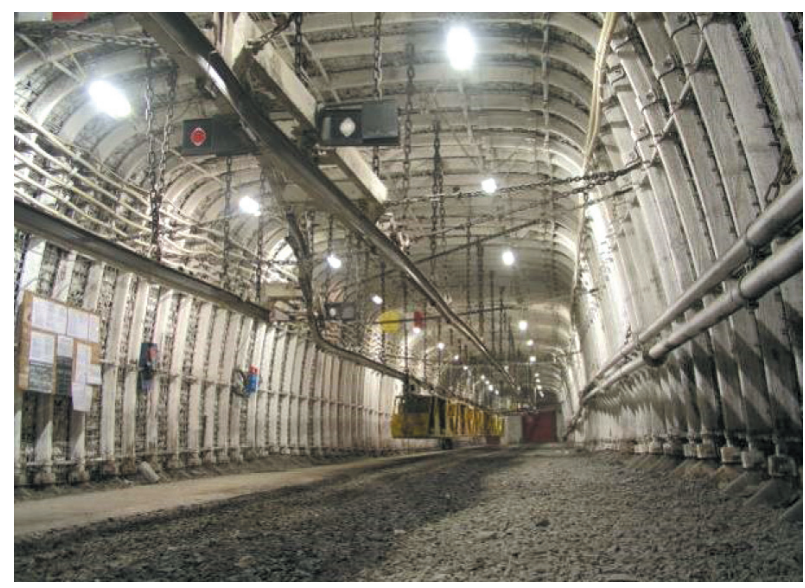

Rys. 43. Zbrojenie ściany w rozcince ścianowej zabezpieczonej obudowa ŁPrP, wykonanie $K$

nych wymiarach. $\mathrm{Z}$ tego też wynikają znaczne, jak na tamte czasy, gabaryty odrzwi. Pierwotnie typoszereg obejmował odrzwia przeznaczone do wyrobisk o maksymalnej szerokości $7200 \mathrm{~mm}$ i wysokości $5000 \mathrm{~mm}$ i był szeroko konsultowany z pierwszym użytkownikiem Kopalnią Węgla Kamiennego „Wujek” [32]. Obecny typoszereg został kilka lat temu istotnie rozbudowany 
o kolejne wielkości odrzwi. Wysokie parametry podpornościowe odrzwi przy znacznych ich szerokościach i małej krzywiźnie stropnicy osiągnięto przez zastosowanie łuku wzmacniającego stropnicę, wykonanego z kształtownika stosowanego na jarzma strzemion. $\mathrm{Na}$ rysunkach 47 i 48 przedstawiono przykłady praktycznego zastosowania odrzwi ŁPrw [33].

W tym samym czasie podjęto próbę połączenia obudowy prostokątnej z łukową (nieco spłaszczoną). W efekcie tego powstały odrzwia hukowo-prostokątne, podwójne typu KaPa [30, 34, 35]. Przeznaczone były

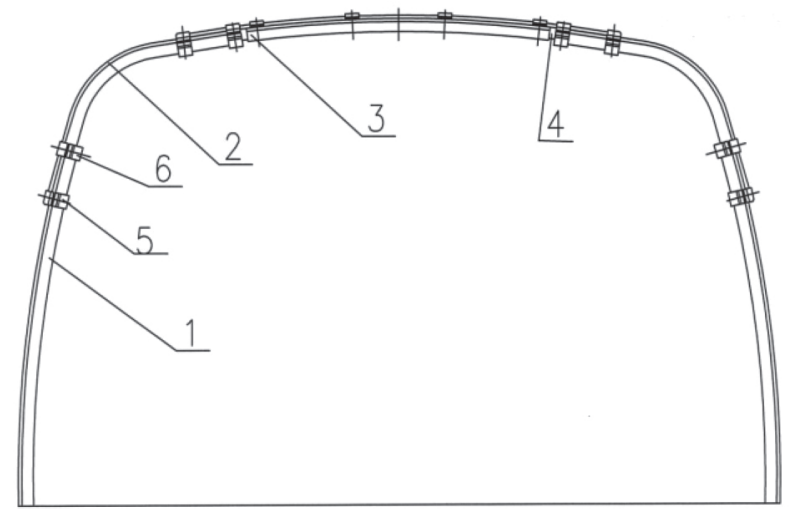

Rys. 45. Odrzwia ŁPrw: 1 - tuk ociosowy,

2 - tuk ociosowy górny, 3 - tuk stropnicowy, 4 - tuk stropnicowy wzmacniający, 5, 6-strzemiona

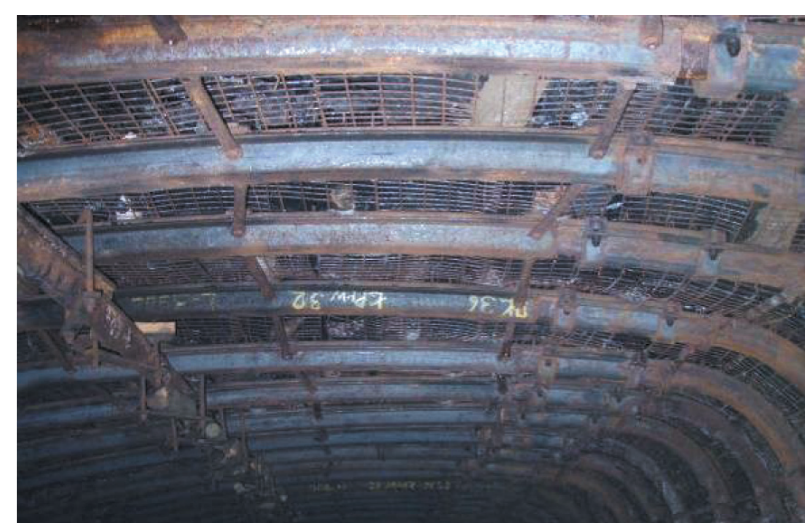

Rys. 47. Rozcinka zabezpieczona obudowa ŁPrw

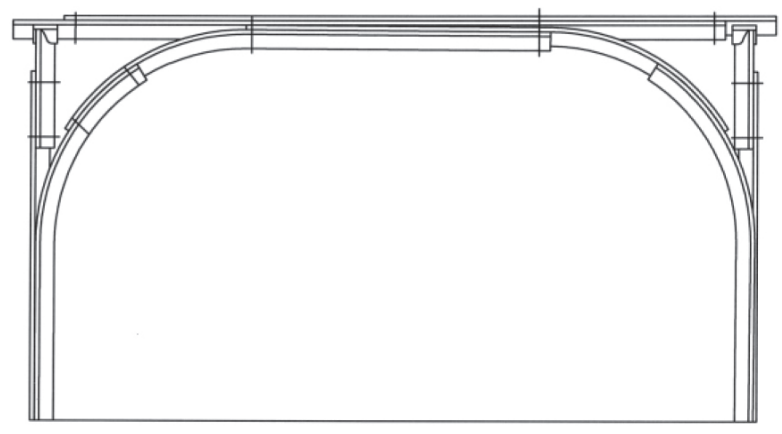

Rys. 49. Odrzwia KaPa przede wszystkim do rozcinek ścianowych o znacznych szerokościach, wykonywanych w trudnych warunkach geologiczno-górniczych, gdzie z uwagi na skały stropowe o niskiej wytrzymałości nie było możliwe przykotwienie stropnicy. Ich konstrukcja jest de facto połączeniem odrzwi ŁPKO z odrzwiami prostokątnymi. Konstrukcję tych odrzwi przedstawiono na rysunkach 49 i 50 . Odrzwia tego typu w połączeniu z odrzwiami ŁPro doskonale nadają się również do zabezpieczania wlotu do wyrobiska w miejscu skrzyżowania [31].

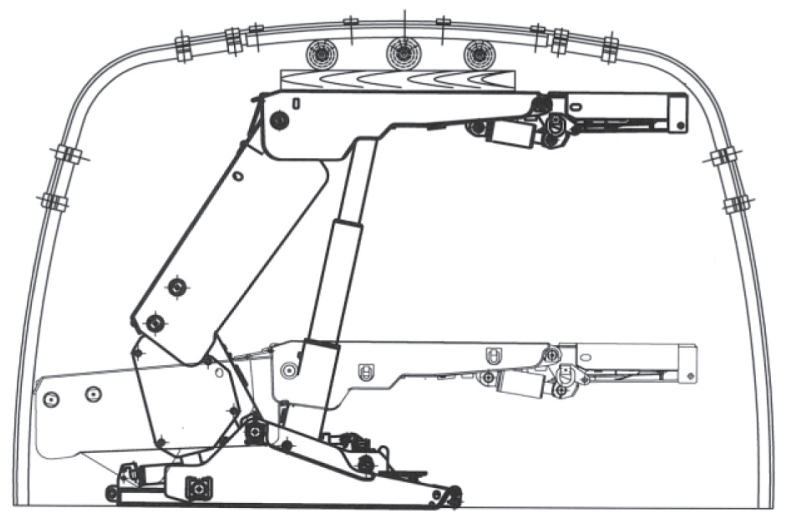

Rys. 46. Odrzwia ŁPrw z wprowadzona sekcja obudowy zmechanizowanej

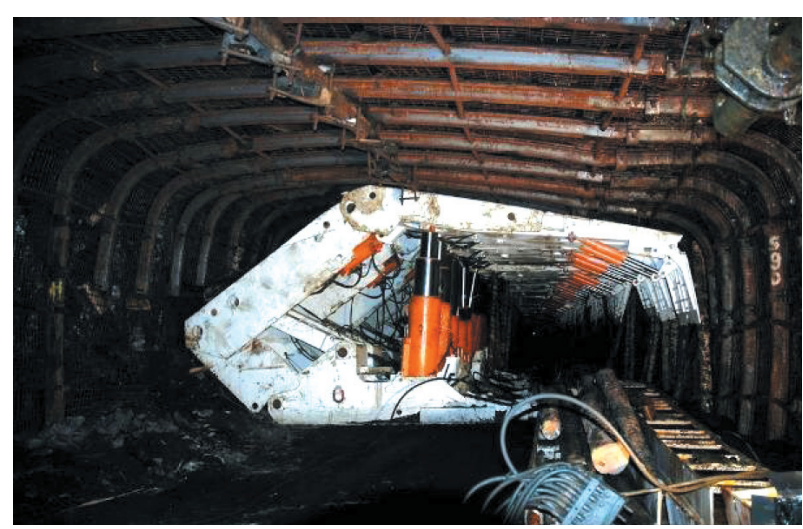

Rys. 48. Zbrojenie ściany, przecinka zabezpieczona obudowa ŁPrw

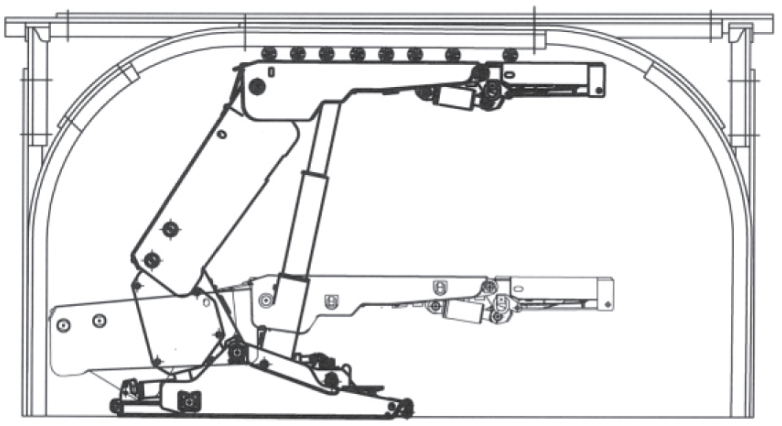

Rys. 50. Odrzwia KaPa z zabudowana sekcja (widok sekcji przed rozparciem i po nim) 
W 2014 roku w Głównym Instytucie Górnictwa został opracowany nowy uniwersalny typoszereg odrzwi łukowych podatnych o oznaczeniu ŁPS [36]. Mimo że oznaczeniem nawiązują do wcześniejszej konstrukcji, są to zupełnie inne odrzwia niż prezentowane wcześniej. Odrzwia przeznaczone są do zabezpieczania wszystkich rodzajów wyrobisk korytarzowych w podziemnych zakładach górniczych. Ich uniwersalność polega na tym, że można je dowolnie konfigurować z 17 wielkości łuków. Dzięki odpowiedniej geometrii łuki różnych wielkości można łączyć ze sobą, uzyskując zarówno zróżnicowane gabaryty odrzwi, jak i różny ich obrys. Poszerza to zakres stosowania odrzwi także poza rozcinki. W ten sposób uzyskano uniwersalny typoszereg odrzwi przy maksymalnej unifikacji elementów.

Odrzwia obudowy ŁPS II generacji zaprojektowane zostały jako czteroelementowe o zarysie lukowym z kształtowników V29, V32 i V36. W podstawowym wykonaniu składają się z czterech jednakowych łuków tej samej wielkości. Każdy z łuków posiada dwie różne krzywizny, z których jedna jest wspólna dla całego typoszeregu. W całym typoszeregu odrzwi zasada kompletowania łuków jest jednakowa - łuki łączone

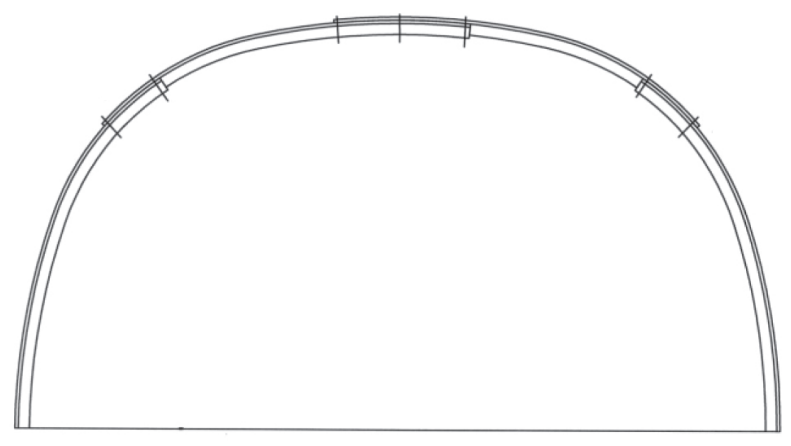

Rys. 51. Uniwersalne odrzwia ŁPS II

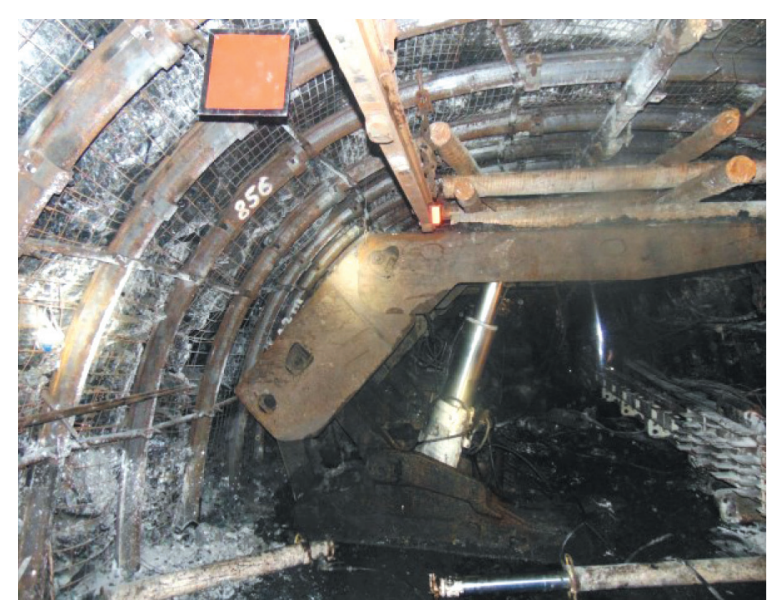

Rys. 53. Zbrojenie przecinki ścianowej wykonanej w uniwersalnych odrzwiach ŁPS II są ze sobą końcami o identycznych parametrach geometrycznych. Konstrukcję tych odrzwi przedstawiono na rysunkach 51 i 52 [8], a na rysunkach 53 i 57 [37] zbrojenie ściany. Obecnie typoszereg podstawowy (cztery łuki jednakowe) obejmuje 18 odrzwi natomiast typoszereg kombinowany (dwie pary łuków różnych rozmiarów) daje możliwość uzyskania kolejnych 306 wielkości odrzwi. Nominalny zakres wymiarowy całego typoszeregu obejmuje szerokości od $5400 \mathrm{~mm}$ do $8800 \mathrm{~mm}$ i wysokości od $2790 \mathrm{~mm}$ do $5200 \mathrm{~mm}$. Z łuków nominalnych możliwe jest skompletowanie 324 różnych wielkości odrzwi, a uwzględniając możliwości zmiany długości łuków ociosowych i wartości zakładek, liczba kombinacji dodatkowo wzrasta.

Tak dużo wariantów odrzwi możliwych do uzyskania w ramach jednego typoszeregu spowodowało konieczność opracowania specjalnego ogólnodostępnego programu komputerowego wspomagającego projektowanie tych odrzwi [38]. Okno tego programu przedstawiono na rysunku 55.

W 2020 roku typoszereg odrzwi ŁPS II generacji został rozszerzony o warianty asymetryczne, przedstawione na rysunkach 56 i 57 [8].

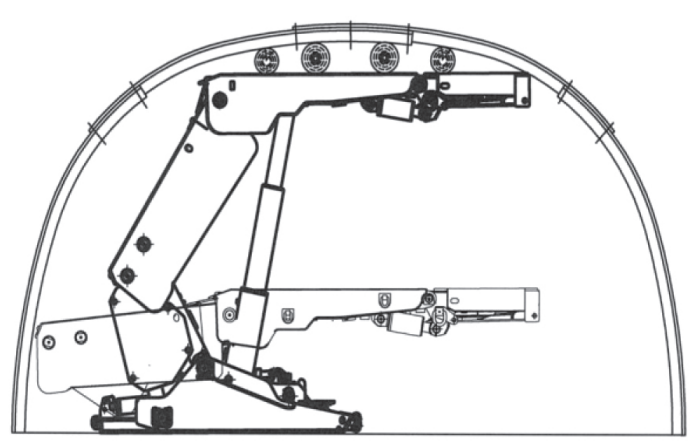

Rys. 52. Uniwersalne odrzwia ŁPS II z wprowadzona sekcja obudowy zmechanizowanej

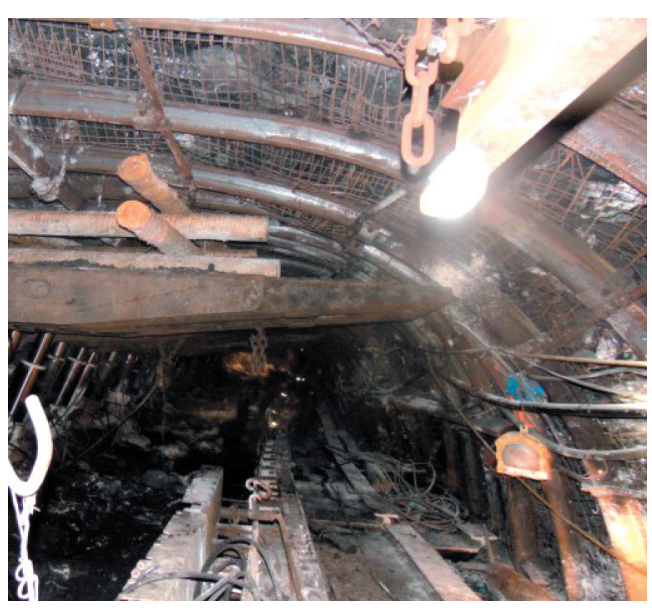

Rys. 54. Zbrojenie przecinki ścianowej wykonanej w uniwersalnych odrzwiach ŁPS II 


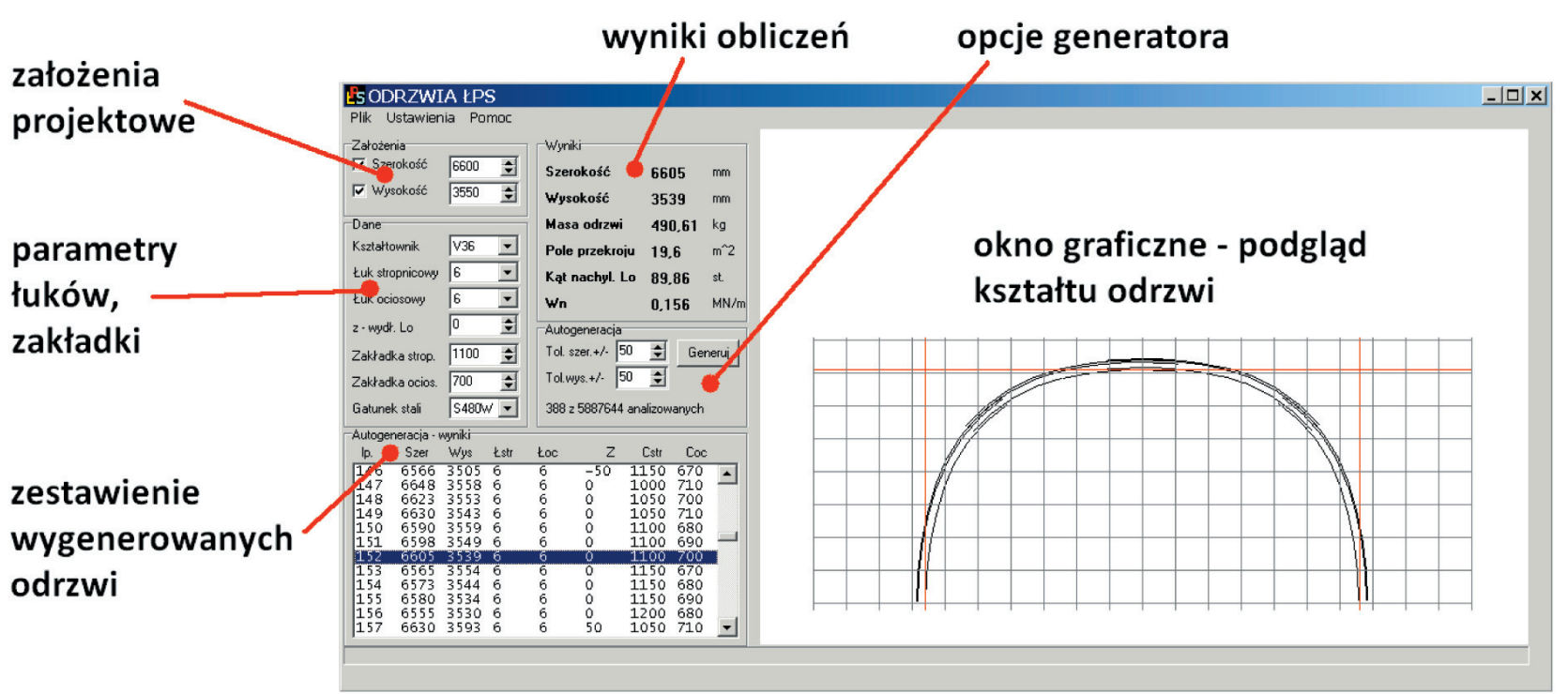

Rys. 55. Gtówne okno programu wspomagającego projektowanie odrzwi ŁPS II [23]

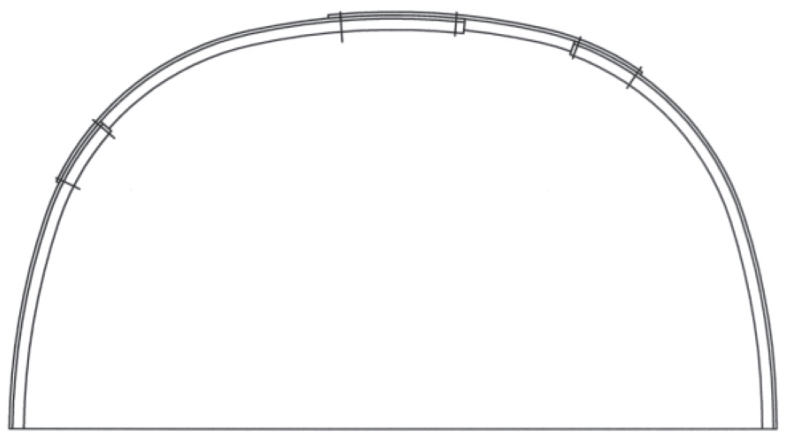

Rys. 56. Uniwersalne odrzwia ŁPS II generacji $w$ wersji asymetrycznej

\section{PODSUMOWANIE}

Na przestrzeni ostatnich czterdziestu lat w ramach trójstronnej współpracy Głównego Instytutu Górnictwa, Huty Łabędy i kopalń węgla kamiennego opracowanych zostało wiele typoszeregów odrzwi dedykowanych do zabezpieczania rozcinek ścianowych. Wiele z nich obejmuje dodatkowo kilka wersji wykonań, co daje użytkownikom - kopalniom kilkanaście, a nawet kilkadziesiąt wariantów konstrukcji odrzwi. Rozwiązania uwzględniają różnorodność warunków geologiczno-górniczych panujących w poszczególnych kopalniach oraz indywidualnych uwarunkowań wynikających z technologii eksploatacji i stosowanych obudów zmechanizowanych.

Ta liczba rozwiązań konstrukcyjnych pozwala na dobór obudowy optymalnej do specyficznych uwarunkowań - wymaganych gabarytów, spodziewanych obciążeń ze strony górotworu, wysokości ściany,

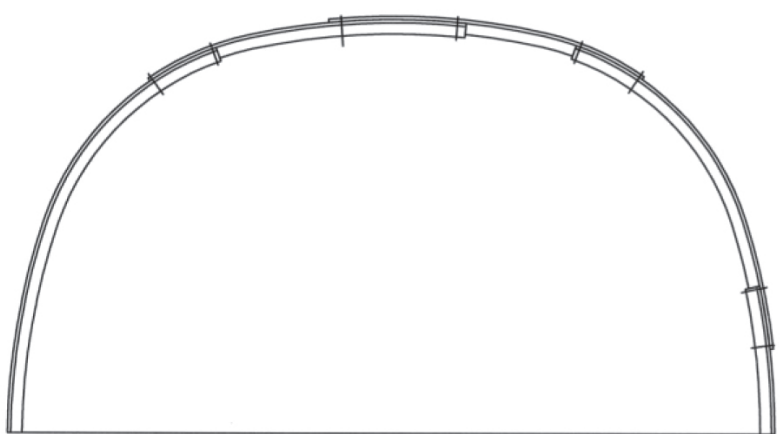

Rys. 57. Uniwersalne odrzwia ŁPS II generacji $w$ wersji asymetrycznej $z$ dzielonym tukiem ociosowym

co przekłada się na bezpieczeństwo oraz efektywność wykonywania prac zarówno w trakcie wprowadzania i rozpierania sekcji obudowy zmechanizowanej, jak i późniejszego rozruchu ściany.

Opracowane rozwiązania są efektem wieloletnich prac projektowych, badawczych oraz zbierania informacji na temat pracy obudowy odrzwiowej i wspólpracy z obudową zmechanizowaną.

Jednocześnie należy spodziewać się dalszego rozwoju tego typu obudowy, szczególnie w sytuacji zwiększania głębokości eksploatacji, pogarszających się warunków geologiczno-górniczych i co za tym idzie - wzrostu obciążeń. Ponadto bardzo prawdopodobne jest zwiększanie rozmiarów poprzecznych rozcinek ścian i obudowy wynikające z postępującej koncentracji wydobycia i zwiększania gabarytów sekcji obudowy zmechanizowanej i całych kompleksów ścianowych. Wiązać się to będzie z pewnością ze zwiększonym udziałem kotwi w sposobach zabezpie- 
czenia rozcinek ścian (obudowa kotwowo-podporowa, przykotwienie odrzwi), zwłaszcza na skutek konieczności redukcji kosztów obudowy przy zachowaniu wysokiego poziomu bezpieczeństwa [39, 40]. Innym kierunkiem rozwoju tych obudów, realizowanym jednocześnie, może być dalsze dostosowanie do warunków górniczych - do wysokości ściany czy typu i rozmiaru sekcji obudowy zmechanizowanej - przez odpowiedni dobór długości łuków i optymalne usytuowanie złączy ciernych. Pozwoli to na sprawniejszy wyjazd sekcji $\mathrm{z}$ rozcinki i uruchomienie ściany.

\section{Literatura}

[1] PN-H-84042:2009: Stale mikrostopowe na ksztattowniki i akcesoria górnicze.

[2] ZN/TT/2012/1: Stal mikrostopowa S550W na kształtowniki i akcesoria górnicze.

[3] PN-93-G-15000-02: Obudowa chodników odrzwiami podatnymi z kształtowników korytkowych. Odrzwia tukowe podatne ŁP, z kształtowników typu V, typoszereg A. Wymiary.

[4] PN-93-G-15000-03: Obudowa chodników odrzwiami podatnymi z kształtowników korytkowych. Odrzwia tukowe podatne ŁP, z kształtowników typu V, typoszereg A. Łuki.

[5] PN-G-15021:2019-05: Obudowa wyrobisk górniczych. Odrzwia podatne z kształtowników korytkowych. Odrzwia łukowe podatne $Ł P$ z ksztattowników typu $V$.

[6] Rotkegel M.: Contribution to the problem of frame clear interval determination of rectangular steel, support, ,Archives of Mining Sciences” 2001, 46, 3: 267-289.

[7] Rotkegel M.: Sity wewnętrzne i reakcje podporowe w elementach obudowy prostokątnej, „Kwartalnik Prace Naukowe Głównego Instytutu Górnictwa” 2009, 1: 51-66.

[8] Katalog Wyrobów dla Górnictwa, Huta Łabędy 2019.

[9] Katalog obudów rozcinek ścianowych „Projekt” - Komisja ds. Obudów Zmechanizowanych i Kierowania Stropem w Podziemnych Zakładach Górniczych przy Centrum Mechanizacji Górnictwa KOMAG, Gliwice 1997.

[10] Bobek R., Śledź T., Ratajczak A., Mąka B., Głuch P.: Doświadczenia ze stosowania obudów podporowych i podporowokotwiowych $w$ przecinkach ścianowych $w$ kopalni „Knurów-Szczygłowice” Ruch Knurów, Warsztaty Górnicze 2012 z cyklu „Zagrożenia naturalne w górnictwie”.

[11] Prusek S., Rotkegel M., Bock S.: Design and control of working support in Polish coal mines based on three-dimensional numerical modeling, $28^{\text {th }}$ International Conference on Ground Control in Mining, Morgantown, USA, 2009.

[12] Prusek S., Rotkegel M., Tor A.: Przebieg kompleksowego procesu projektowania nowej konstrukcji obudowy wyrobisk korytarzowych, Szkoła Eksploatacji Podziemnej, Kraków 2008: 333-351.

[13] Chmielewski T., Nowak H.: Mechanika budowli. Metoda przemieszczeń. Metoda Crossa. Metoda elementów skończonych, Wydawnictwa Naukowo-Techniczne, Warszawa 1996.

[14] Rakowski G., Kacprzyk Z.: Metoda elementów skończonych $w$ mechanice konstrukcji, Oficyna Wydawnicza Politechniki Warszawskiej, Warszawa 1993.

[15] Rusiński E.: Metoda elementów skończonych. System COSMOS/M, Wydawnictwa Komunikacji i Łączności, Warszawa 1994.
[16] COSMOS/M - User's Guide, Structural Research \& Analysis Corp. Los Angeles, USA 1999.

[17] PN-H-93441-3:2004: Kształtowniki stalowe walcowane na goraco dla górnictwa. Kształtowniki typu V. Wymiary.

[18] PN-H-93441-1:2013-12: Ksztattowniki stalowe walcowane na goraco dla górnictwa. Ogólne wymagania i badania.

[19] Brodny J.: Determining the working characteristic of a froction joint in a yieldning support, „Archives of Mining Sciences” 2010, 55, 4: 733-746.

[20] Brodny J.: Tests of Friction Joints in Mining Yieldning Supports Under Dynamic Load, „Archives of Mining Sciences” 2011, 56, 2: 303-318.

[21] Pytlik A.: Experimental studies of static and dynamic steel arch support load capacity and sliding joint temperature parameters during yielding, „Archives of Mining Sciences” 2020, 65, 3: 469-491.

[22] PN-G-15000-05:1992: Obudowa chodników odrzwiami podatnymi z kształtowników korytkowych. Odrzwia tukowe otwarte. Badania stanowiskowe.

[23] PN-G-15022:2018: Obudowa wyrobisk górniczych. Odrzwia podatne z ksztattowników korytkowych. Wymagania wytrzymatościowe i badania.

[24] Rotkegel M., Prusek S., Grodzicki M.: Odrzwia obudowy chodnikowej ze stali nowej generacji. Nowa konstrukcja odrzwi $i$ wyniki przeprowadzonych badań, Szkoła Eksploatacji Podziemnej, Kraków 2012.

[25] Kuziak R., Żak A., Woźniak D., Rotkegel M., Grodzicki M., Nawrot J.: Odrzwia obudowy chodnikowej ze stali II generacji, „Prace Instytutu Metalurgii Żelaza” 2012, 4: 4-17.

[26] Rotkegel M., Prusek S., Kuziak R., Grodzicki M.: Obudowa $Ł P w$ ze stali o podwyższonych parametrach mechanicznych II generacji, Szkoła Eksploatacji Podziemnej, Kraków 2013.

[27] Rotkegel M.: Odrzwia obudowy $Ł P w$ - projektowanie $i$ wyniki badań, „Journal of Sustainable Mining” 2013, 1, 12: 34-40.

[28] Bobek, R., Śledź, T., Ratajczak, A. i Głuch, P.: Porównanie obudowy ŁPKO $i$ ŁPSp w rozcince ściany wydobywczej $w$ trudnych warunkach geologiczno-górniczych $w$ kopalni Knurów-Szczygłowice, „Budownictwo Górnicze i Tunelowe” 2013, 4: $1-9$.

[29] Rotkegel M.: The conditions for proper operation of the archrectangular support, „Archives of Mining Science” 2019, 64, 1: 213-222.

[30] Skrzyński K., Rotkegel M.: Obudowa podwójna dla rozcinek ścianowych wykonywanych $w$ trudnych warunkach górniczo-geologicznych, Prace Naukowe GIG, Seria „Konferencje”, Nr 31, Katowice 1999.

[31] Rotkegel M., Bock S., Witek M., Adamiec P.: Sposób zabezpieczenia połaczenia wyrobisk korytarzowych $w$ warunkach strefy uskokowej, w: Nowe spojrzenie na wybrane zagrożenia naturalne $w$ kopalniach, red. S. Prusek, J. Cygankiewicz, GIG, Katowice 2012: 5-14.

[32] Kowalski E., Rotkegel M., Kościerzyński Z., Wójcik D.: Obudowa tukowo-prosta przeznaczona głównie do zabezpieczenia rozcinek ścian z podsadzka hydrauliczna, „Przegląd Górniczy" 2003, 2: 13-18.

[33] Moszko M.: Stosowanie obudów specjalnych do wykonywania rozcinek ścianowych w kopalni „Ziemowit”, Konferencja Techniczno-Naukowa Huty Łabędy, 2009.

[34] Skrzyński K., Rotkegel M.: Obudowa kombinowana prosto-tukowa jako skuteczne zabezpieczenie rozcinek ścianowych, Szkoła Eksploatacji Podziemnej, Kraków - Szczyrk 2000. 
[35] Kowalski E., Rotkegel M., Rułka K., Skrzyński K.: Obudowy odrzwiowe proste i tukowo-proste, w: Stalowe obudowy odrzwiowe. Nowe rozwiazania konstrukcyjne $i$ metody projektowania, red. K. Rułka, Główny Instytut Górnictwa, Katowice 2006.

[36] Rotkegel M.: Nowy typoszereg odrzwi łukowo-prostych, „Wiadomości Górnicze” 2016, 11: 604-611.

[37] Łaskawiec Ł., Siudyła W., Caban P.: Efekty techniczno-ekonomiczne z zastosowania uniwersalnych odrzwi ŁPS $w$ warunkach KWK „Bobrek-Piekary”, „Budownictwo Górnicze i Tunelowe" 2018, 1: 28-34.

[38] Rotkegel M.: Program komputerowy wspomagajacy dobór obudowy typu ŁPS, „Wiadomości Górnicze” 2017, 1: 8-12.

[39] Pytlik A.: Comparative bench testing of steel arch support systems with and without rock bolt reinforcements, „Archives of Mining Sciences" 2019, 64, 4: 747-764.

[40] Pytlik A.: Tests of steel arch and rock bolt support resistance to static and dynamic loading induced by suspended monorail transportation, „Studia Geotechnica et Mechanica” 2019, 41, 2: 81-92. inż. PIOTR CABAN

Huta Łabędy S.A.

ul. Anny Jagiellonki 45, 44-109 Gliwice

pcaban@hutalab.com.pl

prof. dr hab. inż. KAZIMIERZ STOIŃSKI dr hab. inż. MAREK ROTKEGEL, prof. GIG dr inż. SYLWESTER RAJWA

ADAM GNATOWSKI

dr inż. KRZYSZTOF PACZEŚNIOWSKI

Gtówny Instytut Górnictwa

pl. Gwarków 1, 40-166 Katowice

$\{k$.stoinski; mrotkegel; srajwa; agnatowski;

kpaczesniowski\}@gig.eu

(C) 2020 Autorzy. Jest to publikacja ogólnodostępna, którą można wykorzystywać, rozpowszechniać i kopiować w dowolnej formie zgodnie z licencją Creative Commons CC-BY 4.0. 